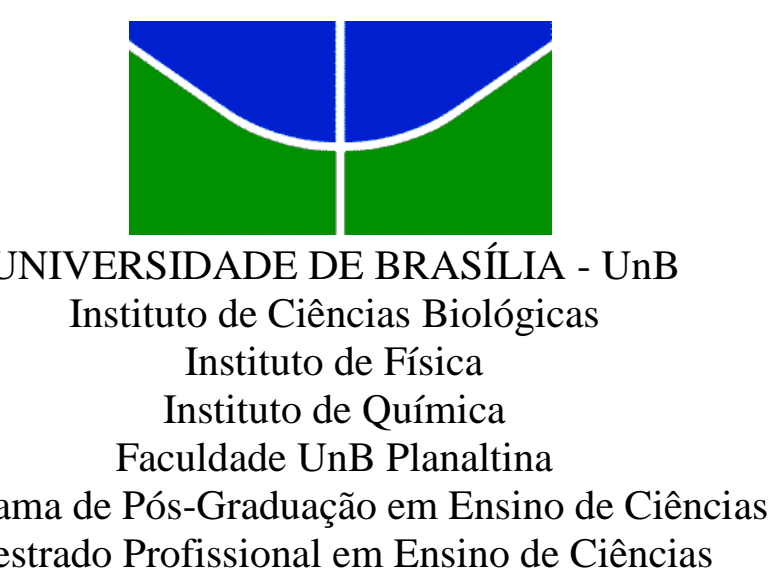

\title{
FORMAÇÃO CONTINUADA A DISTÂNCIA PARA O PROFESSOR DE CIÊNCIAS NATURAIS DO ENSINO FUNDAMENTAL: EDUCAÇÃO EM GEOLOGIA
}

SAMARA DOS ANJOS DA COSTA 


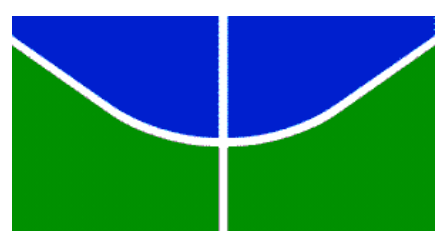

UNIVERSIDADE DE BRASÍLIA - UnB

Instituto de Ciências Biológicas

Instituto de Física

Instituto de Química

Faculdade UnB Planaltina

Programa de Pós-Graduação em Ensino de Ciências

Mestrado Profissional em Ensino de Ciências

\title{
FORMAÇÃO CONTINUADA A DISTÂNCIA PARA O PROFESSOR DE CIÊNCIAS NATURAIS DO ENSINO FUNDAMENTAL: EDUCAÇÃO EM GEOLOGIA
}

\author{
SAMARA DOS ANJOS DA COSTA
}

Dissertação realizada sob orientação da Prof. ${ }^{a}$ Dr. ${ }^{a}$ Alice Melo Ribeiro e coorientação da Prof. ${ }^{a}$ MsC. Anete Maria de Oliveira e apresentada à banca examinadora como requisito parcial à obtenção do Título de Mestre em Ensino de Ciências pelo Programa de Pós-Graduação em Ensino de Ciências da Universidade de Brasília.

Brasília, DF

Março/2016 


\section{FICHA CATALOGRÁFICA}

\section{Costa, Samara dos Anjos da}

Formação Continuada a Distância para o Professor de Ciências Naturais do Ensino Fundamental: Educação em Geologia. Samara dos Anjos da Costa. Brasília, Programa de Pós Graduação em Ensino de Ciências (PPGEC) - Universidade de Brasília, 2016.

$138 \mathrm{p}$.

Dissertação de Mestrado - Universidade de Brasília, PPGEC.

Área de Concentração: Ensino de Ciências.

1. Ciências Naturais. 2. Ensino de Geologia. 3. Formação Continuada de Professores. 4. Educação a Distância. I. Título. 


\section{FOLHA DE APROVAÇÃO}

Samara dos Anjos da Costa

"Formação Continuada a Distância para o Professor de Ciências Naturais do Ensino Fundamental: Educação em Geologia"

Dissertação apresentada à banca examinadora como requisito parcial à obtenção do Título de Mestre em Ensino de Ciências pelo Programa de PósGraduação em Ensino de Ciências (PPGEC) da Universidade de Brasília (UnB).

Aprovada em 4 de março de 2016.

\section{BANCA EXAMINADORA}

Profa Dra Alice Melo Ribeiro - IB / UnB

(Presidente)

Prof. Dr. Rodrigo Miloni Santucci - FUP / UnB

(Membro Titular)

Profa Dra Maria de Lourdes Lazzari de Freitas - FUP / UnB
(Membro Titular)

Profa Dra Jeane Cristina Gomes Rotta - FUP / UnB

(Membro Suplente) 
Dedico este trabalho primeiramente a Deus, pois sem Ele a realização dessa etapa não seria possível. A minha família, minha base, meu tudo. Aos meus avós maternos, Felicidades e João Paulino (in memorian), minhas estrelinhas de ouro. A minha eterna amiga, Vanessa Peres (in memorian). As minhas orientadoras, Alice e Anete, pelo apoio, paciência, dedicação e, a todos que acreditam na educação como a arma mais poderosa de mudança no mundo. 


\section{AGRADECIMENTOS}

Agradeço primeiramente a Deus, razão da minha existência, pelo amparo, amor e sabedoria que me Ele me confiou e concedeu ao longo das batalhas e jornadas da vida.

Aos meus pais, Deuza e Izidro, pelo zelo, carinho, amor, ensinamentos e exemplos de garra. Por sempre se preocuparem com meu desenvolvimento e por me ofertarem todo o alicerce nos momentos em que mais precisei. Vocês são meus grãos de ouro, riqueza imensurável! Que eu possa retribuir todo o amor e cuidado que vocês sempre tiveram comigo. Eu amo muito vocês!

A minha irmã, Isabele, aquela que é a minha versão mais atualizada e geneticamente melhorada também. Somos mais que irmãs, somos amigas, compartilhamos da mesma dádiva de estarmos unidas nesta vida pelo laço do amor mais genuíno e fraterno.

Aos meus familiares, em especial, a minha madrinha Flôr de Liz, minha segunda mãe, aquela que também dedicou parte do seu tempo em prol da minha educação e esteve cuidando de mim ao longo da minha infância e caminhada. Pelas orações, torcidas e desejo em me ver trilhar pelos caminhos mais honrosos desta vida.

Ao meu namorado, Marco Aurélio, por ser esse parceiro do qual tenho tamanha admiração, pelo cuidado, amparo ante as minhas dificuldades, carinho e amor despendido a mim. Por acreditar no meu potencial e por sempre me incentivar a lutar pelos meus sonhos!

Aos meus colegas de turma do mestrado, em especial àqueles que são mais que colegas, são amigos e, me acompanharam desde a graduação até a conclusão de mais uma etapa dentro do âmbito acadêmico, MsC. Antonia Adriana, MsC. Lays Martins e MsC. Rodrigo Xavier, obrigada pelos momentos de descontração, pelo apoio durante os momentos de aflição, pelos momentos de estudo e por serem esses profissionais dos quais tenho tanto apreço.

Aos meus amigos de graduação, Adriana Machado, Aline Sampaio, Alzineide Barros, Andrezza Romênia, Diego Jácome, Dilmar Barreto, Fernanda Kurcharski, Gabriela Dutra, Grazielle Rocha, Júlia Viegas, Luana Oliveira, e Reneida Mendes, que mesmo trilhando caminhos diferentes, nunca deixaram a essência da amizade de lado, semeando este laço para uma vida toda.

Às minhas meninas, Evelyn Ferreira, Fernanda Melo, Kamila Sousa e Millena Aquino, pelos momentos compartilhados, por sempre desejarem o meu sucesso, pela amizade 
recíproca e por serem o meu elo ao verdadeiro sentido da frase: "amigo é a prova de que não é preciso ter o mesmo sangue para ser irmão". Obrigada por tudo, irmãs minhas!

Aos meus amigos da vida, Andreia de Almeida, Andrelly Lopes, Aurisleide Ferreira, Emmerson Campos, Jefferson Ferreira, Karen Barbosa, Kelen Barbosa e Thaís Rezende, que sempre me apoiaram e que mesmo em meio à tamanha correria e responsabilidades do dia-adia, nunca deixaram de me fornecer apoio, compreendendo as minhas ausências e acreditando na minha evolução constante, dentro da jornada profissional escolhida por mim.

A minha orientadora Prof. ${ }^{a}$ Dr $^{\mathrm{a}}$. Alice Melo Ribeiro, pela amizade e profissionalismo, por ter me acompanhado desde o início da minha jornada acadêmica, guiando os meus passos e me proporcionando experiências e desafios que, certamente, contribuíram imensamente para a transformação da profissional que eu me tornei hoje. Palavras não são o suficiente para agradecer tamanho apoio ofertado ao longo desses anos!

A minha coorientadora Prof. ${ }^{\text {a }}$ MsC. Anete Maria de Oliveira, a qual tenho inestimável admiração pela pessoa, profissional e mulher de fibra que é. Por todas as aprendizagens e conhecimentos divididos e ofertados desde o dia em que a conheci, por sempre me incentivar com tamanho afeto, reconhecendo minhas qualidades, quando nem eu mesma acreditava existir. Você é um dos meus exemplos e inspiração dentro da docência!

A Prof. ${ }^{a}$ Dr. ${ }^{a}$ Renata Cardoso de Sá Ribeiro Razuck, pelas contribuições fornecidas na etapa de qualificação do presente trabalho.

A minha banca examinadora, composta pela Prof. ${ }^{a}$ Dr. ${ }^{a}$ Jeane Cristina Gomes Rotta, Prof. ${ }^{a}$ Dr. ${ }^{a}$ Maria de Lourdes Lazzari de Freitas e Prof. Dr. Rodrigo Miloni Santucci, pelas contribuições e sugestões levantadas, em prol do aprimoramento desta investigação.

Aos professores, sujeitos de pesquisa que toparam em participar dessa construção, pelas trocas de experiências, aprendizagens, saberes. Sem o envolvimento de vocês, nada disso seria possível!

Aos cientistas naturais, Edelvan Correia, Gaby Camargo e Margarete Lisboa, pelo auxílio prestado nos encontros presenciais do curso, proposição da presente investigação.

Ao Prof. MsC. Franco de Salles Porto, pelas dicas e orientações valiosíssimas prestadas antes do ingresso no Programa de Pós Graduação em Ensino de Ciências (PPGEC) da Universidade de Brasília (UnB), a Prof. ${ }^{a}$ Dr. ${ }^{a}$ Maria de Lourdes Lazzari de Freitas, por ter me acolhido em seu projeto "Programa de Fomento para Projetos de Aprendizagem e Inovação Social: Promoção a Saúde” ao longo destes dois anos, pelos conhecimentos e 
experiências compartilhadas e, aos demais professores de graduação e de toda minha trajetória educacional que sempre me inspiraram e incentivaram.

Ao PPGEC e a UnB pela oportunidade em cursar o mestrado e, em especial aos professores que tive o prazer de conhecer e conviver ao longo desses dois anos, Cássio Laranjeiras, Eliane Mendes, Gerson Mól, Maria Luíza, Maria Rita, Mariana Zancul e Ricardo Gauche, pelas instruções e aulas instigadoras.

A equipe do Centro de Ensino Fundamental 01 do Paranoá, Distrito Federal, por me receber tão bem em meu primeiro trabalho como docente, pelos auxílios prestados e pela experiência compartilhada e, aos meus queridos e inesquecíveis alunos.

Ao Decanato de Extensão (DEX) da UnB, pela confecção dos certificados entregues após o término do curso.

A todos que, direta ou indiretamente, contribuíram para finalização dessa etapa de suma importância para o meu sucesso profissional, ratifico aqui os meus sinceros agradecimentos! 
"Da minha aldeia vejo quanto da terra se pode ver no Universo... Por isso a minha aldeia é tão grande como outra terra qualquer. Porque eu sou do tamanho do que vejo e não do tamanho da minha altura...".

(Fernando Pessoa) 


\section{RESUMO}

A Geologia é uma área de estudo que não se apresenta no currículo educacional enquanto disciplina. Suas temáticas encontram-se distribuídas nas diversas áreas das ciências exatas e humanas, que integram diferentes objetos de investigação na educação básica. Seu estudo é indispensável para o desenvolvimento de uma visão crítica frente à dinâmica planetária. Apesar de tamanha importância, sua abordagem encontra-se excessivamente descontextualizada, fragmentada e dotada de equívocos ao ser explanada durante as aulas de Ciências Naturais. Este fato se deve primordialmente a uma série de algoritmos que dificultam a prática do professor e concomitante o desenvolvimento de uma sensibilização ambiental e global por parte dos educandos. Frente a essa questão é que o presente trabalho buscou evidenciar a perspectiva de professores de ciências no que diz respeito ao ensino de Geologia, propondo em conjunto com esses, um curso de formação continuada, objetivando a abordagem das temáticas geológicas pautadas em uma perspectiva interdisciplinar e ambiental. Sendo assim, a proposta metodológica do presente estudo caracterizou-se como pesquisa colaborativa. Para coleta de dados foi realizada inicialmente uma entrevista semiestruturada com 15 docentes do Ensino Fundamental da Educação Básica. A partir das concepções coletadas e analisadas, foi planejado e desenvolvido juntamente com os entrevistados, um curso de formação continuada - proposição da presente investigação abordando-se temas pertinentes do estudo da Geologia, bem como estratégias de ensino passíveis de serem utilizadas em sala. Posteriormente, o curso foi aplicado adotando-se a modalidade da educação a distância, dos 15 docentes participantes, 9 concluíram esta etapa. Após a implantação da proposta foi realizada novamente uma entrevista semiestruturada individualizada com os participantes, visando avaliar os impactos e as contribuições do curso para a formação destes. Os resultados mostraram-se satisfatórios uma vez que, o curso levou os docentes a enriquecer os saberes intrínsecos a Geologia, agregando-os com as vivências desencadeadas em outros momentos da formação, a se aproximar com as tecnologias de acesso a informação, mediante o contato com a educação a distância, além de propiciar uma reflexão acerca da prática pedagógica e das lacunas presentes no ensino de ciências. Desse modo, foi possível inferir que a formação continuada deve ser uma prática constante na vida do professor, tendo em vista que esta pode contribuir diretamente para a minimização das prospecções presentes no ensino, ao se tratar de diferentes temáticas, dentre elas a da construção do conhecimento frente ao ensino de Geologia.

Palavras-chave: Ciências Naturais. Ensino de Geologia. Formação Continuada de Professores. Educação a Distância. 


\begin{abstract}
As not a subject of the Basic Education, Geology and its contents occur scattered in other disciplines of sciences and humanities of the Elementary School Curriculum. Its understanding is imperative to achieve a critical and planetary point of view. Despite such importance, the geological approach applied in Natural Sciences classes remains decontextualized, fragmented, and far from no mistakes. Due to this, the teacher practice becomes difficult, the global and environmental awareness by the pupils as well. In order to answer the needs related to teaching geology of Natural Science teachers, a collective built continuing teacher training course, with an environmental and interdisciplinary perspective, and focused on geology was suggested. A collaborative approach characterize the methodological procedures of this research. A first semi-structured interview with 15 teachers of Elementary schools was undertaken. After reviewing the answers, the course - of this research proposal - of geology and teaching strategies were collectively built. A virtual distance education platform was used to offer the course to fifteen teachers, concluded only by nine of them. To evaluate the course, an individual semi-structured interview with each attendant was undertaken at last. The final result were considered satisfactory, once the knowledge on Geology was upgraded within a constructivism approach guiding the course, as well as an improvement on TIC was supported by the virtual platform. Besides, the course offered an opportunity to discuss the pedagogical practice and issues of teaching Science. As a final conclusion, continuing teacher training must be a steady experience to minimize teaching issues, including those of geology.
\end{abstract}

Keywords: Natural Sciences. Geology education. Continuing teacher training. Distance Education. 


\section{LISTA DE ABREVIATURAS E SIGLAS}

AVA - Ambiente Virtual de Aprendizagem

CN - Ciências Naturais

CTS - Ciência Tecnologia e Sociedade

CNE - Conselho Nacional de Educação

DEX - Decanato de Extensão

EaD - Educação a Distância

EB - Educação Básica

EF - Ensino Fundamental

EM - Ensino Médio

LDB - Lei de Diretrizes e Bases da Educação

MEC - Ministério da Educação

MOODLE - Modular Object-Oriented Dynamic Learning Environment

PCN - Parâmetros Curriculares Nacionais

PIBID - Programa Institucional de Bolsa de Iniciação à Docência

SEEDF - Secretaria de Estado de Educação do Distrito Federal

TCLE - Termo de Consentimento Livre e Esclarecido

TIC - Tecnologias de Informação e Comunicação 


\section{SUMÁRIO}

APRESENTAÇÃ

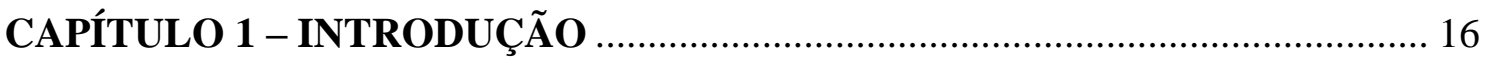

1.1 A Geologia e o Processo Educativo ........................................................................ 19

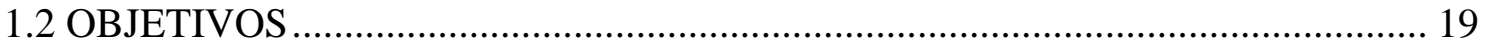

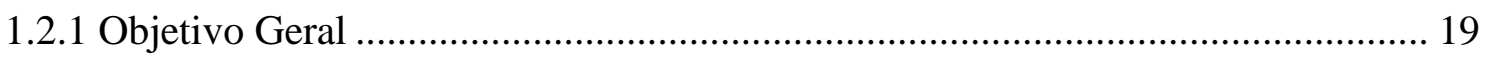

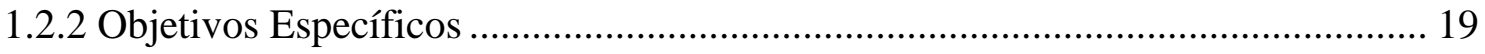

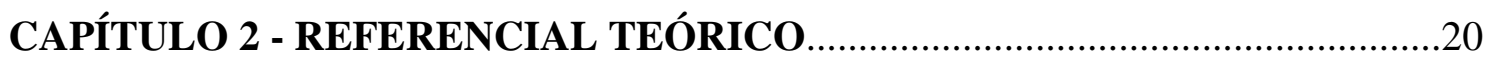

2.1 Epistemologia do Pensamento Geológico ........................................................... 20

2.2 A Geologia na Perspectiva CTS (Ciência-Tecnologia-Sociedade) ........................... 22

2.3 O Processo Interdisciplinar e o Ensino de Geologia ............................................. 25

2.4 Formação Continuada de Professores de Ciências Naturais....................................28

2.5 Possíveis Contribuições da Educação a Distância na Formação de Professores........31

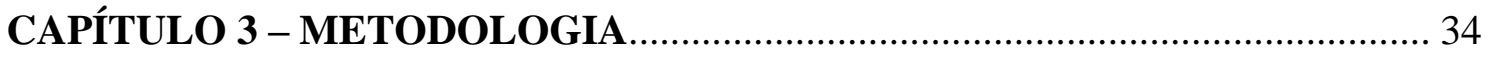

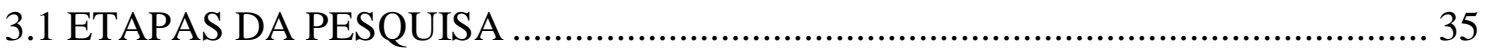

3.1.1 Seleção dos sujeitos de pesquisa .................................................................. 35

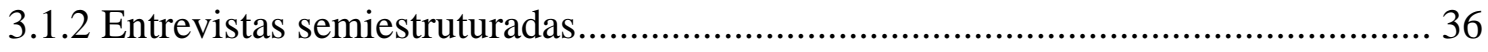

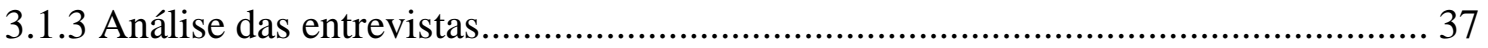

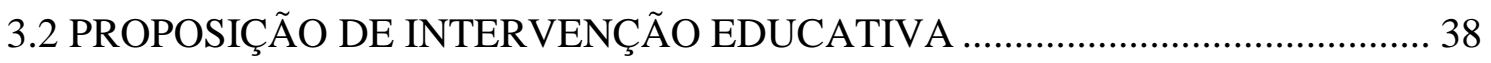

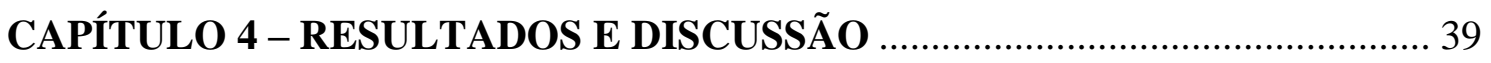

4.1 PERFIL DOS PROFESSORES DE CIÊNCIAS NATURAIS ................................ 40

4.1.1 Caracterização dos sujeitos de pesquisa .......................................................... 40

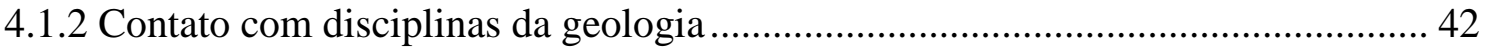

4.1.3 Importância da compreensão da dinâmica do planeta Terra na resolução de

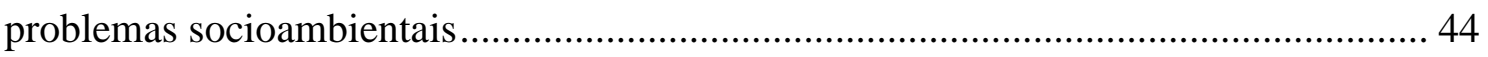

4.1.4 Dificuldades e/ou facilidades ao trabalhar temas de Geologia nas aulas .............. 47

4.1.5 Estratégias de ensino e recursos didáticos utilizados para trabalhar temas da

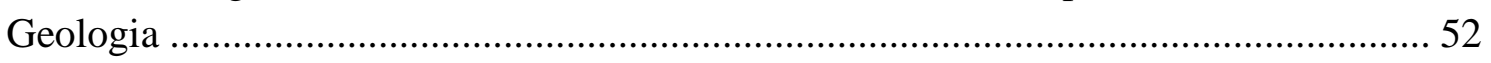

4.2 APLICAÇÃO DA PROPOSIÇÃO EDUCATIVA - CURSO "EDUCAÇÃO EM

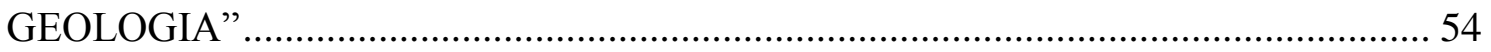

4.3 PERCEPÇÕES ACERCA DA PROPOSIÇÃO DESENVOLVIDA ........................ 58

4.3.1 Contributos da formação continuada para a prática docente ................................ 58 
4.3.2 Um olhar acerca das atividades desenvolvidas - Geologia em destaque .64

4.3.3 Contribuições do curso "Educação em Geologia" para o professor de Ciências Naturais 68

4.3.4 A Educação a distância como uma modalidade de formação continuada 72

4.3.5 Comentários acerca da proposição educativa ....................................................... 76

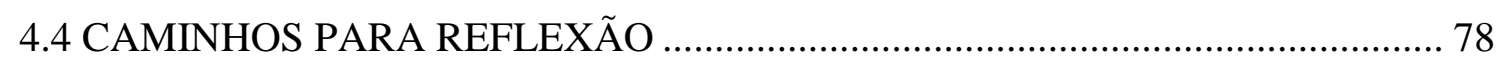

4.4.1 A construção da formação profissional ............................................................... 78

4.4.2 Aspectos promissores do curso "Educação em Geologia" ..................................... 80

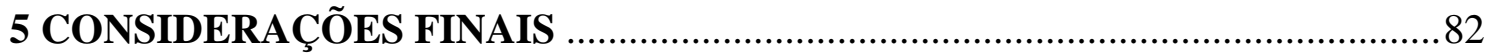

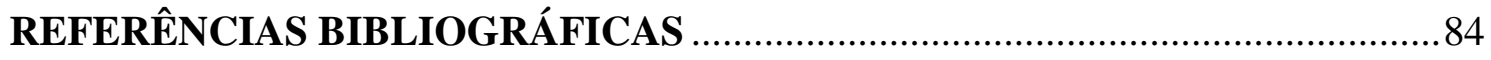

APÊNDICE A - Termo de Consentimento Livre e Esclarecido ..................................94

APÊEDICE B - Roteiro da entrevista semiestruturada (Pesquisa Inicial) .....................95

APÊNDICE C - Roteiro da entrevista semiestruturada (Pesquisa Avaliativa) .............96

APÊNDICE D - Proposição de Intervenção Educativa..................................................98 


\section{APRESENTAÇÃO}

Desde sempre tive o interesse por diversas áreas do conhecimento. Quando cursava o ensino fundamental eu alimentava em meus desejos a vontade de trabalhar com a natureza e todos os seus seres integrantes, logo vi nas Ciências Biológicas um meio para realizar tal aproximação. Ao cursar o ensino médio eu me encontrava rodeada de possibilidades profissionais e a dúvida começava a transparecer cada vez mais em meu ser. Foi aí que um dos meus professores me apresentou o curso de Licenciatura Plena em Ciências Naturais da UnB, afirmando que o mesmo possuía caráter interdisciplinar e que nele eu poderia me encontrar, correlacionando minhas diversas áreas de interesse.

Durante a graduação vivenciei diversas experiências, e logo no segundo semestre do curso comecei a participar de um projeto de extensão intitulado "Prodocência". Este me permitiu dar início à prática docente, de modo a aperfeiçoa-la, disseminando os saberes adquiridos enquanto graduanda do curso de Ciências Naturais. Nele tive a possibilidade de vivenciar a prática docente, antes mesmo de cursar as disciplinas de estágio, estas que são obrigatórias dentro do curso e que possuem o intuito de favorecer a inserção do licenciando dentro do cotidiano escolar, possiblitando a prática dos conhecimentos adquiridos ao longo da graduação, bem como a compreensão do papel da docência, além de permitir o desenvolvimento de saberes e habilidades necessárias para futura atuação profissional. Essa vivência forneceu-me uma maior segurança e novas perspectivas, despertando e fortificando o meu anseio em ser professora-pesquisadora.

Após ter trabalhado com diversas áreas do ensino de ciências, continuei a atuar no "Prodocência" e, nos últimos dois anos de graduação, este passou a abordar uma linha de pesquisa voltada para o ensino de Geociências. Com a experiência adquirida no projeto senti a necessidade de trabalhar as Geociências numa perspectiva integrada, que fornecesse subsídios para que os educandos pudessem construir conhecimentos que favoreçam uma posição mais crítica e reflexiva em relação aos acontecimentos e problemáticas que envolvem o meio ambiente. Foi pensando neste contexto que desenvolvi o meu Trabalho de Conclusão de Curso, intitulado "O Reconhecimento das Geociências na Educação Básica: uma proposta de material pedagógico para professores do Distrito Federal”.

Ao concluir a graduação sempre visei dar continuidade à minha formação profissional, foi então que resolvi pleitear uma vaga no PPGEC, buscando sempre aprimorar meus conhecimentos, abrir meus horizontes às novas formas de aliar as ciências ao campo 
educacional, além de aperfeiçoar a minha prática pedagógica e contribuir para a formação dos professores de ciências no que tange a área de Geologia.

Sendo assim, no início de 2014 eu ingressei no PPGEC e optei pela linha de pesquisa "Formação de Professores de Ciências da Natureza" objetivando dar continuidade ao trabalho desenvolvido com professores ao longo da jornada acadêmica. Neste mesmo ano passei a integrar a equipe do Curso de Licenciatura em Biologia a distância da UnB, no grupo multidisciplinar, atuando como professora II, no qual exerci tarefas de apoio aos estudantes de graduação. Foi mediante a esta experiência que surgiu a ideia de trabalhar com formação de professores adotando-se a modalidade de educação a distância.

Para que a proposta fosse completamente delineada, foi necessário cursar as disciplinas ofertadas no PPGEC, logo no primeiro ano de programa, finalizei as disciplinas, estas que foram cruciais para o direcionamento da pesquisa. Os encontros foram ricos momentos de aprendizagem, discussão e construção de ideias que amparadas à literatura científica, ganhavam cada vez mais magnificência a cada olhar pedagógico vislumbrado pelos professores, estes que a cada encontro, tornaram possível a compreensão de que somos seres em construção e de que nossas experiências, tanto profissionais e pessoais, são reflexos da nossa bagagem em constante formação.

A escolha e veiculação entre os temas de "Formação Continuada" e "Ensino em Geologia" deu-se pelo desejo em tornar-me uma profissional reflexiva - competência essa que a meu ver é indispensável para a construção da identidade profissional e do fazer docente - e ao mesmo tempo, comprometida com a forma como vem sendo discutida e abordada as questões ambientais, dentro do limite conteúdista trabalhado em sala de aula. A educação, se tratando de ciências, requer um ensino mais problematizador, capaz de tornar o aluno ator do processo decisório, de modo que, este possa intervir positivamente frente ao meio ambiente e ao planeta Terra.

Ainda no primeiro semestre de 2015, qualifiquei o meu projeto. Foi uma das etapas mais importantes dentro do estudo, pois foi um momento para enriquecer a proposta e vislumbrá-la aos olhos da banca, uma vez que as considerações feitas e as sugestões enfatizadas contribuíram significativamente para que eu pudesse dar continuidade ao trabalho, aprimorando meus saberes e ideais frente à investigação construída.

Após a qualificação dei prosseguimento às demais etapas de pesquisa e nesse meio tempo outras oportunidades de experienciar o campo acadêmico, a educação a distância e a formação continuada foram surgindo. No segundo semestre de 2015 passei a atuar com tutora no curso de Licenciatura em Biologia a distância da UnB. Foi uma experiência bastante 
promissora e que contribuiu significativamente para o delineamento da minha proposição, uma vez que, a mesma também foi ofertada nesta modalidade de ensino.

Ao final de 2015 tive a oportunidade de lecionar pela Secretaria de Estado de Educação do Distrito Federal (SEEDF), atuando como docente nas disciplinas de Ciências Naturais e Matemática, momento este que foi importantíssimo para ressignificar a minha vontade e ímpeto em ser professora, em ser uma profissional comprometida com o trabalho desenvolvido no campo social e na realidade dos meus alunos. Foi um período curto, mas muito gratificante, no qual pude vivenciar na íntegra uma das frases de Paulo Freire (2000, p. 67), "se a educação sozinha não transforma a sociedade, sem ela tampouco a sociedade muda". Ao longo desta jornada acadêmica, pude perceber o quanto tenho crescido, e o quanto anseio em me tornar um agente transformador, capaz de fazer a diferença na vida daqueles que verdadeiramente acreditam na mudança por meio da educação. 


\section{CAPÍTULO 1 - INTRODUÇÃO}

\subsection{A Geologia e o Processo Educativo}

A Geologia apresenta-se como uma ciência que trata da história e evolução da Terra, tendo como assunto primordial a compreensão do processo histórico-geológico (FIGUEIRÔA, 2009; POTAPOVA, 1968). Como uma das Ciências do Sistema Terra (WESTBROEK, 2002) ou Geociências, seu estudo abrange conceitos e métodos de investigações presentes nos campos disciplinares de várias ciências específicas como a História, Física, Química, Biologia e Geografia, não deixando de buscar também, para ser totalmente compreendida, os conhecimentos da Filosofia e da Matemática.

Ao permear por várias ciências da natureza, exatas e humanas, a Geologia culmina assim, em uma área que desencadeia um importantíssimo papel no contexto social e em seus diversificados subcampos por se dotar de natureza interdisciplinar. Seu estudo adquire caráter demasiadamente relevante no ensino, uma vez que se faz necessário que os educandos de todos os níveis de escolaridade façam uma leitura do mundo, possibilitando o estabelecimento das relações entre a atividade humana e a dinâmica natural do planeta, compreendendo as influências positivas ou negativas que podem ser exercidas perante a natureza (CARNEIRO; TOLEDO; ALMEIDA, 2004; HEVIA, 2009). Desse modo, a situação ambiental vigente requer análises e discussões globalizadas, contextualizadas e interdisciplinares de cidadãos que já estejam preparados desde sua Educação Básica (EB) para tal.

Pensando por esse viés - formação de cidadãos brasileiros conscientes e preparados para tomadas de decisões sustentáveis para o bem comum nos dias atuais - e na busca por um ensino com a participação construtivista do aluno, foi que houve no Brasil a reformulação da EB brasileira de acordo com a Lei de Diretrizes da Educação Nacional de n ${ }^{\circ}$. 9394, promulgada em 1996 (BRASIL, 1996).

Dentro dessa nova política pública, o Ministério da Educação (MEC), por meio do Conselho Nacional de Educação (CNE), elaborou as diretrizes de orientação ao professor da $\mathrm{EB}$ na forma dos Parâmetros Curriculares Nacionais (PCN) propondo em seu texto atividades de ensino que permitam enfatizar as diversas inter-relações existentes entre as disciplinas (BRASIL, 1998). 
No entanto, na prática a aplicação dessas sugestões encontrou diversos entraves por partes dos professores que não estavam familiarizados com a interdisciplinaridade. De acordo com Cunha e Krasilchilk (2000), os cursos de licenciatura existentes quando da promulgação da nova Lei de Diretrizes e Bases da Educação (LDB) eram específicos, ou seja, habilitavam professores para o ensino de ciências na EB em competências específicas, como Química, Biologia e Física. Cursos esses amplamente conceituados, mas que possuem um currículo considerado insuficiente para abarcar uma visão mais generalizada de mundo necessária para o ensino de ciências, considerando que a formação interdisciplinar do professor nessas referidas licenciaturas não é prioridade. Segundo Magalhães Júnior e Pietrocola (2011), o curso de Licenciatura Plena em Ciências Naturais se diferencia dos demais por prover uma formação mais equânime e generalista aos professores das áreas que constituem o ensino de ciências, entre elas a Geologia.

A prática da interdisciplinaridade requer grande reforma no pensamento e na forma de ensinar e compreender o mundo. Assim, no contexto atual da educação, a inclusão da Geologia, cujo raciocínio científico é essencialmente interdisciplinar, vem contribuir e facilitar as pretensões do atual ensino brasileiro na formação de cidadãos competentes para tomadas de decisões sustentáveis (BACCI, 2009; CARNEIRO; TOLEDO; ALMEIDA, 2004; FRODEMAN, 2010; KASTENS et al., 2009). Carneiro e Santos (2012, p. 88), argumentam que as temáticas da Geologia incorporadas e abordadas na EB articulam o "entendimento dos processos naturais com o das atividades humanas e possibilita analisar as origens, as causas e as consequências da degradação ambiental”.

Os PCN salientam que os temas mais pertinentes da Geologia encontram-se distribuídos nos diversos componentes curriculares do Ensino Fundamental (EF) e Ensino Médio (EM) (BRASIL, 1998). Entretanto, Toledo (2005) enfatiza o caráter ainda fragmentado dos conteúdos apresentados no documento. Assim, uma abordagem articulada e organizada em uma estrutura fragmentada de conteúdos, não permite que o professor realize um delineamento coeso dos processos.

Apesar de inúmeros esforços por parte do educador, a construção do conhecimento nas bases da Geologia também se encontra limitada por uma série de outros fatores que vão além da formação inicial desses docentes e da estruturação dos PCN, dos quais se pode citar: a) livros descontextualizados que não abarcam a realidade vivenciada pelos educandos (COMPIANI, 2005; NASCIMENTO, 2011); b) escassez de materiais didáticos, projetos e atividades de pesquisa que estejam voltados para a área do ensino de Geologia (COMPIANI, 2005; NÓVOA, 2009); c) precárias condições de trabalho, até a falta de materiais didáticos 
básicos que os auxilie nas práticas pedagógicas, dificultando dessa forma a ânsia em diminuir as lacunas encontradas atualmente no ensino (FAZENDA, 1998).

O professor é o colaborador direto nas questões que envolvem o processo educativo, é ele que intervém, acompanha, conduz, cria, reformula e aperfeiçoa as condições e os estímulos mediadores para o processo de aquisição do conhecimento pelo aluno (GARRIDO, 2001). O aperfeiçoamento da sua prática não ocorre somente durante a sua formação inicial, mas durante a sua trajetória profissional, nela há um contínuo processo de autoformação e reelaboração dos saberes de acordo com as experiências desencadeadas na prática pedagógica. Assim, é importante pensar na formação continuada dos docentes principalmente no que tange a Geologia para que os problemas listados anteriormente sejam progressivamente dirimidos.

No momento, a maioria dos professores da EB tem formação específica, o que torna interessante a formação continuada no sentido de ampliar seus conhecimentos e práticas didáticas por meio do ensino de Geologia que é a proposta essencial dessa investigação. Espera-se, num futuro próximo, que professores mais capacitados no entendimento das relações sistêmicas do planeta levem os alunos à compreensão das relações existentes entre ciência, tecnologia e sociedade (CTS), tornando-os cidadãos responsáveis, éticos e autônomos, conhecedores da importância da educação científica como contributo para a vida prática e para a resolução de demandas (MARTINS; CARNEIRO, 2014).

Além de a prática pedagógica ser um dos quesitos que contribuem para o aperfeiçoamento do profissional da educação enquanto docente, os cursos de formação continuada possuem o intuito de preparar, ressignificar a prática pedagógica do professor, frente às demandas que emergem cotidianamente no contexto educacional. Gadotti (2009, p. 38), reforça essa óptica ao enfatizar que "é necessário contextualizar, globalizar, relacionar, buscar as múltiplas causas das coisas. Não basta reformar o ensino, sem reformar o pensamento".

Diante das concepções discutidas anteriormente e como parte integrante do papel educativo exercido pelas instituições escolares, apresentamos tamanha preocupação com a formação dos professores de Ciências Naturais $(\mathrm{CN})$, principalmente no que diz respeito aos temas socioambientais.

Dessa forma, a proposta deste trabalho consistiu em traçar um perfil dos professores da EB, acerca do ensino de Geologia no EF, propondo um curso de formação continuada a distância. A disponibilidade da Educação a Distância $(\mathrm{EaD})$ oferecida pela UnB, somada à rotina enfrentada pelos professores no ambiente escolar que lhes ocupa muito tempo como aulas, planejamentos, coordenações em grupo, dentre outras questões respaldam a nossa 
escolha pela formação a distância. A proposta aplicada consiste em um curso semipresencial, com parte dos encontros realizados no ambiente virtual de aprendizagem - moodle ${ }^{1}$.

A mediação dos conceitos geológicos, por meio de um curso de formação continuada, visa promover a complementação dos conhecimentos frente à Geologia, favorecendo a abordagem interdisciplinar dos saberes com outras áreas do ensino e, contribuindo para a realização de uma mediação coesa e linear dos temas trabalhados nas aulas de $\mathrm{CN}$, com o objetivo maior de desenvolver no cidadão brasileiro uma consciência ambiental planetária.

\subsection{OBJETIVOS}

\subsubsection{Objetivo Geral}

Propor um curso de formação continuada a distância para professores de Ciências Naturais do Ensino Fundamental de uma cidade do DF, abordando conceitos pertinentes da área da Geologia, focando-se na interdisciplinaridade dos saberes e na fortificação da prática pedagógica dos docentes envolvidos.

\subsubsection{Objetivos Específicos}

- Reconhecer os aspectos teórico-metodológicos presentes na formação dos professores de Ciências Naturais.

- Identificar os anseios de professores quanto ao assunto de Geologia.

- Promover a discussão de temas inerentes ao ensino de Geologia.

- Verificar se o curso de formação continuada proposto "Educação em Geologia" trouxe contribuições para a prática docente, no tocante ao ensino da referida área.

\footnotetext{
${ }^{1}$ A plataforma Moodle - Modular Object-Oriented Dynamic Learning Environment é o ambiente onde ocorrem as trocas de conhecimento entre alunos, tutores, professores e a prática educativa. É uma espécie de sala de aula virtual que sustenta as atividades de ensino, sendo possível conectá-la em qualquer computador que tenha acesso a internet. Mediante o cadastro de senha pessoal, o usuário passa a ter acesso a exercícios, fórum de discussões, tira dúvidas, entre outras ações.
} 


\section{CAPÍTULO 2 - REFERENCIAL TEÓRICO}

\subsection{Epistemologia do Pensamento Geológico}

A Geologia, como já evidenciado, é a ciência responsável pelo estudo da Terra, pela apresentação dos seus processos evolutivos, históricos e funcionais indispensáveis para a compreensão da variabilidade dos recursos naturais e dos organismos conhecidos atualmente. Ao longo de bilhões de anos a Terra sofreu várias mudanças, seus sistemas interativos, sejam eles externos e/ou internos, culminaram em uma série de transformações que exigem uma visão integrada para o entendimento das ações desencadeadas por esses processos no passado, presente e futuro planetário (PRESS et al., 2006).

Os processos naturais que ocorrem no domínio do planeta Terra, se desenvolvem em uma escala de tempo e espaço bastante variada e são estudados e explorados por diferentes ciências, entre elas estão a Física, Química, Biologia e Matemática. Sendo assim, a Geologia possui uma característica tanto das ciências da natureza, como das ciências históricas, o que permite a realização da análise dos eventos sistêmicos e complexos observados em nosso sistema aberto (GALVÃO; FINCO, 2014). Conforme apontado por Engelhardt e Zimmermann (1988), a Geologia infere causas desconhecidas por meio de efeitos conhecidos, em outras palavras, ela permite vislumbrar a configuração do presente com vistas à interpretação dos fatos ocorridos no passado.

A constituição dos fenômenos vivenciados pelo planeta sugere o desenvolvimento de uma observação apurada, capaz de apreender as etapas e as mudanças mais significativas que ocorreram em cada evento identificado ao longo do tempo na Terra. Desse modo, a Geologia, além de se apresentar como uma ciência histórica e interdisciplinar possui também uma característica interpretativa (FRODEMAN, 2010), pois para sua compreensão, diversos mecanismos que envolvem a cognição do pensamento humano precisam ser adotados, entre eles o pensamento lógico-dedutivo, a abstração espacial, a imaginação, a criatividade, o uso de analogias e a capacidade de interpretação dos fenômenos e fatos. Além dessas habilidades, Andrews (1998) enseja que para o estudo dos sistemas geológicos, se tratando de paisagens e afloramentos, por exemplo, requer ainda uma reconstituição mental dos processos em 4D, incluindo a dimensão do tempo, a fim de entender a evolução dos processos e fenômenos geológicos. 
De acordo com Frodeman (2010, p. 87), “a fundamentação geológica consiste de uma combinação de procedimentos lógicos". Acredita-se que essa concepção é comum às ciências experimentais. Entretanto, a Geologia utiliza-se dessa linha para combinar-se com as técnicas de raciocínios que imperam no campo científico. É como se garantir o entendimento dos fatos geológicos fosse como montar um quebra-cabeça utilizando-se de informações que, na maioria das vezes, não se encontram mais presentes. Logo, exige-se uma interpretação das evidências deixadas no passado, dos resultados de transformações remotas e da evolução dos aspectos que envolvem a constituição do sistema planetário em si.

O entendimento da história planetária evoca para a significação das interpretações realizadas frente aos eventos que caracterizam os processos do planeta Terra atualmente. Para tanto há que se preponderar que o raciocínio geológico é uma operação complexa uma vez que, se exige uma compreensão da importância e do papel exercido pela natureza e do espaçotempo ocupado por ela. Conforme exposto por Justina (2002, p. 20), a Geologia nos remete ao deslocamento "do tempo presente para um tempo passado, numa relação pretérita com o conhecimento, na tentativa de lançá-lo a um futuro mais promissor”.

Frente a essa percepção temos que a interpretação das evidências encontradas nos registros geológicos utiliza-se de procedimentos comparativos com as causas atuais, no que gerou a teoria do Atualismo que diz que "o presente é a chave do passado". No entanto, linhas de raciocínios distintas, tentaram e ainda tentam explicar os processos que geraram essas evidências, conhecidas pelos princípios do Uniformitarismo e Catastrofismo.

O primeiro teve como percursor o geólogo, químico e filósofo James Hutton (17261797). O Uniformitarismo considera que “os processos da dinâmica geológica, lentos e graduais, estariam operando de uma maneira análoga à que poderia ser verificada nos processos em operação na atualidade" (FARIA, 2014, p. 107). Sendo assim, os períodos geológicos poderiam ser estudados conforme as relações e semelhanças estabelecidas com os processos atuais - inclusive em intensidade e tomados sempre como graduais - desencadeados pela Terra.

Já o Catastrofismo teoria de Georges Cuvier (1769-1832), preponderava que os fenômenos da dinâmica terrestre observáveis no presente, também vistos somente como lentos e graduais, não seriam suficientes para explicitar os fenômenos e rupturas bruscas evidenciadas no pretérito. Assim, para Cuvier a intensidade dos fenômenos do passado teria que ser muito mais intensa para justificar tais mudanças repentinas, que não seriam mais observáveis na atualidade. Mais tarde, com o desenvolvimento científico, o Catastrofismo 
passou a considerar os fenômenos atuais como consequências de catástrofes ocorridas na configuração geológica do passado (FARIA, 2014).

Os dois princípios mencionados, mesmo adotando o mesmo pressuposto de analogia entre presente e passado, possuem visões limitadas da velocidade e intensidade dos fenômenos geológicos. Ambos descartam a possibilidade real de que tantos processos lentos ou bruscos podem ocorrer em processos geológicos atuais e pretéritos e muitas vezes podem coexistir num único processo. As intensidades, frequências e abrangências dos fatos não ocorrem obrigatoriamente sempre da mesma forma, podem variar. Desse ponto de vista, mesmo havendo interpretações distintas, as duas teorias coexistem. Ambas convergem quando adotam o atualismo, pois utilizam o presente para explicar o passado.

A construção do pensamento epistemológico da Geologia com base na compreensão de processos geológicos, sejam eles atuais ou pretéritos, ao longo de poucos ou milhares de anos, por mecanismos de raciocínio lógico-dedutivo, análogo e interpretativo, subsidiados pela abstração espacial e pela interdisciplinaridade de saberes é que fez surgir a necessidade de expandir, introduzir e debater o conhecimento geológico e histórico da Terra nas bases educacionais. Visto que, os cidadãos necessitam desse entendimento para compreensão dos fatos mediante ao que vem ocorrendo nas esferas atuais, com o intuito de desenvolver uma visão sustentável e interdisciplinar, que permita um melhor gerenciamento da exploração dos recursos naturais.

Tendo em vista que o raciocínio geológico é uma das habilidades que os estudantes possuem dificuldade em dominar, a elucidação integrada e interdisciplinar dos eventos planetários é uma das premissas que visa alavancar o conhecimento no campo de estudo da Geologia (CARNEIRO, et al., 2005). Sendo assim, acredita-se que o entendimento da ordem planetária, culminada nos aportes de uma ciência que é histórica e ao mesmo tempo interpretativa, poderá intervir nas problemáticas ambientais que ameacem a ordem global comum a todos os seres integrantes do planeta, fazendo com que os estudantes dominem conhecimentos básicos inerentes a Geologia.

\subsection{A Geologia na Perspectiva CTS (Ciência-Tecnologia-Sociedade)}

A ciência começou a destacar-se nos diversos currículos escolares internacionais em meados do século XIX, antes deste período as obras científicas eram destinadas a diversos 
públicos em geral. No Brasil, a educação científica obteve uma incorporação tardia no currículo, somente por volta de 1930 que se deu início ao processo de busca pela inovação no ensino de ciências. Professores e cientistas brasileiros preocuparam-se em transmitir uma visão moderna da ciência, adequando o ensino à realidade brasileira, já que este estava moldado conforme a realidade americana e europeia, visando assim proporcionar novos conhecimentos ao público da época (KRASILCHILK, 1980; SANTOS, 2007).

A difusão do conhecimento científico no contexto histórico sempre necessitou de uma ampla interpretação, reflexão e avaliação da ciência e tecnologia enquanto desencadeadoras de aspectos positivos e negativos perante a sociedade e seus indivíduos. A avaliação do impacto da ciência requer uma formação que favoreça o desenvolvimento do pensamento sistêmico e da criticidade dos alunos frente aos assuntos mais emergentes do cotidiano, possibilitando-os a utilização desses conhecimentos adquiridos no âmbito escolar e nos diversos discursos que envolvem tomadas de decisões (ZABALA; ARNAU, 2010).

Para que de fato a formação para o exercício da cidadania ocorra é necessária uma mudança imediata não só dos conteúdos programáticos, como também nos processos metodológicos de ensino. Gadotti (2009, p. 142) reforça essa problemática e acrescenta que a educação para a cidadania demanda "uma revisão dos nossos currículos educacionais, uma reorientação de nossa visão de mundo da educação como espaço de inserção do indivíduo em uma comunidade que é local e global ao mesmo tempo".

A utilização de projetos curriculares com embasamento CTS no contexto da educação brasileira vem beneficiar o ensino-aprendizagem do educando, visando fomentar a educação em uma perspectiva mais humanista, desenvolver melhor estigma nos alunos em relação aos conhecimentos da ciência e meios de aprendizagem, e preparar os alunos para reflexões e o exercício da cidadania, capacitando-os a analisar problemáticas, que venham ao encontro de possíveis soluções (MAGALHÃES; TENEIRO-VIEIRA, 2006; SANTOS; MORTIMER 2002).

Para tanto, o conhecimento científico necessita de uma abordagem no ensino que contemple não só a natureza da ciência e os seus resultados enquanto atividade científica, como também a formação humana centrada na discussão de valores e a compreensão da ciência como prática social, posto a relevância da abordagem CTS nos documentos curriculares, de modo que, seja possível promover a aquisição de conhecimentos articulados com o meio em que os estudantes estão inseridos, agregando habilidades, conhecimentos e valores (BYBEE, 1987). 
Apreende-se que tanto o discurso que justifica a inserção da ciência no currículo educacional brasileiro, como a proposta de ensino embasado na abordagem em CTS, apresenta o mesmo propósito básico de formação de um indivíduo com uma visão global preparado para atuar efetivamente na melhoria desse mundo, o que não difere sobremaneira do que o ensino de Geologia pode oferecer. Essa relação é tão intrínseca que Santos e Mortimer (2002) ao justificarem tal educação fazem uma correlação direta com a Geologia ao listarem alguns dos assuntos que podem ser abordados no contexto brasileiro, adotando-se os aspectos do currículo com abordagem CTS, tais como: "exploração mineral e desenvolvimento científico, tecnológico e social", focando-se na exploração dos recursos minerais por grandes empresas e os impactos desencadeados por essas atividades; "poluição ambiental e ocupação humana", discussão da ocupação desordenada, desmatamento de áreas, poluição dos recursos hídricos; "geração de lixo", questões sobre impacto do consumo na natureza; "fontes de energia", propostas de implantação e efeitos perante a sociedade; "meio ambiente", envolvendo ações de preservação e compreensão das problemáticas atuais (SANTOS; MORTIMER, 2002). Com base nos temas expostos, torna-se possível exercer uma abordagem voltada para o estabelecimento de uma educação planetária (BOFF, 1996; GADOTTI, 2009; MORIN, 2002), preocupada com as relações existentes entre ciência, tecnologia, sociedade e meio ambiente.

A Geologia é parte integrante desse processo dialógico, ela estabelece relação com o exercício da tomada de decisões coerentes e saudáveis, inerentes a uma educação voltada para a sustentabilidade, constituindo-se como um veículo de contextualização, em prol de uma formação cidadã que esteja preocupada com as questões sociais mais emergentes. Da mesma forma, Gadotti (2009), defende uma alfabetização ecológica, a Pedagogia da Terra, cujos princípios são norteados pelo entendimento do funcionamento do planeta para um convívio sustentável entre todos que o habitam.

Dada a importância da abordagem e correlação de temas com enfoque CTS, da capacidade de interpretação, julgamento e avaliação das questões frente aos discursos que se fazem presentes na atualidade é que Pedrinaci (2012) se aprofunda mais nas questões geológicas quando lista algumas das características que definem uma pessoa letrada em Geologia como sendo aquela que: a) tem uma visão geral sobre como a Terra funciona e usa esse conhecimento base para explicar, por exemplo, a distribuição de vulcões e terremotos ou para compreender alguns dos fatores que podem causar alterações globais do planeta; b) possui uma boa perspectiva temporal acerca das profundas mudanças que afetaram nosso planeta no passado e exercem uma melhor compreensão do presente; c) percebem algumas 
das principais interações entre a humanidade e o planeta, os riscos naturais que podem afetálo, a dependência dos recursos naturais e a necessidade para promover a utilização sustentável dos mesmos; d) é capaz de localizar e selecionar informações relevantes para alguns dos processos que afetam a Terra, fazendo perguntas pertinentes sobre eles, avaliando as possíveis evidências existentes para conclusões; e por fim e) pode usar princípios geológicos básicos em prol de sua relevância para construção do conhecimento científico.

Entretanto, e apesar da importância, o que se tem visto é a repetição na história da educação do que já aconteceu com as propostas teoricamente oferecidas pelos PCN e também pela educação planetária, de que no contexto escolar do dia-a-dia não há uma preocupação em aplicar de fato propostas educacionais como os currículos com ênfase em CTS. As estratégias metodológicas empregadas usualmente continuam não impulsionando os educandos a compreenderem o real significado da argumentação científica e a sua aplicação nos mais variados contextos. Sendo assim, permanece o "status" de uma ciência teórica e informativa, mas pouco aplicada, no qual os educandos acabam não sendo preparados para o pleno exercício da cidadania, não exercem a criticidade e não tomam conhecimento das problemáticas socioambientais desencadeadas pelo rápido progresso tecnológico e científico.

Dentre os aspectos necessários e talvez o mais problemático para a aplicação efetiva da abordagem CTS encontra-se a prática da interdisciplinaridade, posto que o pensamento especializado na educação brasileira possui raízes profundas e de longa data como já exposto. Entender o atual estado da arte da interdisciplinaridade, apresentado a seguir de forma resumida, em especial com relação à Geologia, nos auxiliará a vislumbrar os caminhos possíveis para se enfrentar a questão.

\subsection{O Processo Interdisciplinar e o Ensino de Geologia}

Muito se fala sobre interdisciplinaridade, mas o que exprime seu conceito? A palavra “interdisciplinar" surgiu em meados do século XX. Entretanto, as ideias e concepções de unificada, integradora e o que é ser interdisciplinar foram desenvolvidos desde épocas remotas pela filosofia antiga (FAZENDA, 1998).

Para Freire (1987) a interdisciplinaridade consiste num processo de construção do conhecimento, com bases nas relações do sujeito com os diferentes aspectos que fazem parte do campo social. Já Germain (1991, p. 143) acrescenta que a interdisciplinaridade "pressupõe 
a existência de ao menos duas disciplinas como referência e a presença de uma ação recíproca". Em suma, ela nos remete a uma troca e cooperação entre vários conceitos sobre um mesmo tema, a interação e associação desses conceitos constituem a formação de uma concepção sobre o elemento (MORIN, 2002).

Jantsch e Bianchetti (1995) acrescentam ainda que a elucidação desse mecanismo deve exceder a mera justaposição de disciplinas, sendo compreendida como uma concepção de exploração das potencialidades e articulações previstas no campo da ciência. Nesse sentido, a interdisciplinaridade curricular requer uma preservação das especificidades das áreas pertencentes ao currículo, visando "assegurar sua complementaridade dentro de uma perspectiva de troca e conhecimento" (FAZENDA, 1998, p. 57).

Reigota (1994, p. 26), por sua vez, defende mais a integração das disciplinas do que sua separação quando aponta que "a tradicional separação entre as disciplinas de humanas, exatas e naturais perde sentido, já que o que se busca é o conhecimento integrado de todas elas para a solução dos problemas".

Nos PCN, documento que constitui o primeiro nível de concretização curricular atual do ensino brasileiro, percebe-se a ênfase na proposta da interdisciplinaridade, mas sem desconsiderar saberes específicos. Os conteúdos curriculares são organizados em disciplinas, áreas e/ou por princípios norteadores, eixos e temas, mas visam tratar os conteúdos de modo integrado, exemplificado pelas várias sugestões teóricas ao longo do texto de tratamento interdisciplinar, realizando uma articulação entre o cotidiano social e o saber escolar (BRASIL, 1998). No entanto, ainda se faz necessário uma análise minuciosa de toda proposta dos PCN, considerando que algumas concepções interdisciplinares se mostram tácitas e por esse motivo há quem acredite que são irrisórias.

Em relação à Geologia, o modo como os temas estão expostos no documento ainda não enfatiza o caráter interdisciplinar que se espera no ensino da área. Ocorre sim uma primeira tentativa teórica de se relacionar a Geologia com as demais disciplinas, haja vista que em seu texto os tópicos mais pertinentes da área encontram-se distribuídos nos diversos componentes curriculares do EF e EM (BRASIL, 1998). Entretanto, Toledo (2005), numa análise dos PCN do Ensino Médio, afirma que a efetividade da interdisciplinaridade sugerida com os temas geológicos fica a desejar, pois a maneira fragmentada com que os temas são expostos não permite a compreensão sistêmica do planeta. A autora ressalta ainda consequências negativas que podem surgir caso essas sugestões sejam seguidas ao fomentar que "os alunos são privados do conhecimento necessário para adquirir a visão de funcionamento global e interdependente da natureza, correndo o risco de desenvolverem, ao 
contrário do ideal, uma visão imediatista e utilitária da natureza" (TOLEDO, 2005, p. 33). Conforme Martins e Carneiro (2014, p. 372), “deve-se integrar a interdisciplinaridade como fator primordial de mobilização de saberes, visando à valorização dos recursos naturais (vivos e não-vivos, renováveis ou não) de forma sustentada".

Entretanto, para que a proposta de ensino almejado nos PCN seja de fato alcançada, é importante que as práticas da interdisciplinaridade sugeridas no referido documento sejam aperfeiçoadas, fornecendo subsídios palpáveis para que o professor passe a adotá-las em sala de aula, levando este a superar as premissas estabelecidas no documento, transcendendo suas meras intenções (MARTINS; CARNEIRO, 2014).

Nas escolas, onde na prática as propostas das diretrizes nacionais deveriam ser aplicadas, a interdisciplinaridade no âmbito do cronograma escolar está relegada aos projetos transversais. A compartimentação em disciplinas específicas da maioria dos conteúdos curriculares dificulta a realização da associação entre as partes pelos alunos, e mais, estes acabam não conseguindo transpor os conhecimentos para sua realidade e, na maioria das vezes, alimentam a concepção de que determinado saber concebido na sala de aula não possui nenhuma aplicabilidade em seu cotidiano. Isso é válido não só para os temas geológicos, mas para as ciências como um todo.

O exercício da interdisciplinaridade ainda é um longo caminho a ser percorrido, e mesmo que este se faça presente nos grandes discursos educacionais, torna-se necessário romper as articulações rasas e ir ao encontro aos mecanismos que permitam a sua realização em uma amplitude mais profunda. Com a atualização dos profissionais da educação e a chegada dos professores com formação em $\mathrm{CN}$, a abordagem interdisciplinar poderá ganhar grande espaço, sendo possível estabelecer uma conexão verídica entre os diversos saberes.

Entretanto, a prática interdisciplinar ainda é mais árdua principalmente para professores formados numa visão mais especialista. No que tange ao ensino de Geologia, por exemplo, o professor que possui formação em uma "única" área apresenta dificuldade para fazer correlações entre os diversos componentes da ciência, esta que é dotada de muitos saberes, pertencentes a um mundo repleto de conhecimentos diversificados. A abordagem delimita-se em um enfoque compartimentado e fragmentado, o que restringe a integração dos saberes e suas relações, pois considera seus elementos de modo isolado, desvalorizando a percepção global (MARTINS; CARNEIRO, 2014).

O professor especialista, principalmente, necessita ainda aprender a praticar a interdisciplinaridade para poder ensiná-la. A Geologia é promissora nesse sentido por ser dotada de perspectivas particulares, de acordo com cada disciplina que a compõe, adquirindo 
dessa maneira um caráter globalizante e integrador de ensino (CARNEIRO; SANTOS, 2012; MORIN, 2002). O professor ao assimilar os processos do pensamento geocientífico compreende e percebe a ação da interdisciplinaridade. E, no que concerne aos aprendizes, esta permite que estes desenvolvam uma visão global de mundo, tornando-se aptos para "articular, religar, contextualizar, situar-se num contexto e, se possível, globalizar, reunindo os conhecimentos adquiridos" (MORIN, 2002, p. 29).

A adoção de práticas interdisciplinares deve partir do docente em conjunto com profissionais de outras áreas do saber e com a escola no qual este se encontra inserido, favorecendo a participação direta em atividades e projetos que promovam uma visão mais unificada do ensino. Profissionais e pesquisadores ligados à universidade podem promover a parceria com as escolas, enfatizando a promoção de atividades com esse caráter no ensino. É mediante a execução de trabalhos dotados com essa perspectiva interdisciplinar que será possível socializar conhecimentos, transformar comportamentos, desenvolver competências e fomentar a participação crítica e responsável dos alunos diante dos fatos trabalhados.

\subsection{Formação Continuada de Professores de Ciências Naturais}

O trabalho docente exige algumas percepções que devem ser levadas em consideração no ato da formação. Para se chegar até a concepção do que Nóvoa denominou como "bom professor", é necessário haver conhecimentos que induzam os alunos à aprendizagem; ao estabelecimento de uma cultura escolar, no qual os docentes possam integrar-se à profíssão e, por conseguinte, possam estabelecer trocas de experiências com grupos de professores; exige trabalho em equipe, com o intuito de promover ações colaborativas e coletivas em prol da intervenção de projetos educativos na escola; e por fim o compromisso social com a diversidade cultural, com os fatores que envolvem valores e princípios (NÓVOA, 2009).

É de suma importância que o professor realize momentos de reflexão acerca de sua prática docente, a fim de identificar quais pontos em sua formação necessitam de uma ampla modificação e como esta pode estabelecer uma relação harmoniosa entre o saber e o fazer cotidiano no ambiente escolar. Nesse sentindo, a formação continuada deve fornecer alternativas "como resposta às necessidades reais dos professores de acordo com a perspectiva de educação permanente e, ainda, promover, apoiar e incentivar as iniciativas pedagógicas das escolas e dos professores" (GONÇALVES, 1992, p. 168). 
Nóvoa (1995, p. 28) enaltece que a formação continuada "passa pela experimentação, pela inovação, ensaio de novos modelos de trabalho, processos de reflexão e investigação". Nela é possível enxergar o exercício da prática pedagógica como uma construção constante de identidade, valores e saberes.

As lacunas identificadas na formação inicial e na prática educacional levantam a importância da formação continuada como uma via de contribuição para a resolução dos problemas estruturais e conceituais identificados pelos professores no ensino. Como corroborado por Nóvoa (1995, p. 16), "mais do que um meio de aquisição de técnicas e de conhecimentos, a formação de professores é o momento-chave da socialização e da configuração profissional”. Pimenta $(2005$, p. 12) explicita que a identidade profissional se constrói a partir da:

Revisão constante dos significados sociais da profissão, da revisão das tradições. Mas também da reafirmação de práticas consagradas culturalmente e que permanecem significativas; práticas que resistem a inovações porque prenhes de saberes válidos às necessidades da realidade (PIMENTA, 2005, p. 12).

A formação continuada dos professores é justificada por Schnetzler (1996) mediante três razões: a) a melhoria do processo de ensino-aprendizagem, só acontece quando este reflete acerca da sua prática pedagógica visando seu aprimoramento; b) a utilização de pesquisas educacionais e sua articulação em sala de aula implicam em tornar o professor o agente pesquisador de sua própria prática; e por fim c) os professores, em sua maioria, possuem uma visão reducionista da atividade docente, e concebem-na como uma prática que basta ensinar conteúdos e adotar estratégias pedagógicas específicas.

Os cursos de formação continuada sugerem a quebra dos paradigmas dos processos de formação adquiridos em outros momentos, e que não acrescentam mais na prática do professor, levando em consideração o seu desenvolvimento pessoal e profissional, uma vez que estes não se encontram dissociados da profissão. Nóvoa (1995, p. 27) enseja essa questão e acredita que o desafio atual está centrado justamente na "valorização de paradigmas que promovam a preparação de professores reflexivos, que assumam a responsabilidade do seu próprio desenvolvimento profissional".

A concretização de cursos de formação adotando-se a modalidade a distância também merece o destaque de algumas ações que visam favorecer o andamento e assegurar a qualidade dessa implementação, entre elas estão a reavaliação da sua postura, prática pedagógica, adoção de metodologias de ensino e uma melhor compreensão dos conflitos enfrentados cotidianamente no exercício de sua profissão. Novóa (1995) e Pimenta (2005) sugerem que o planejamento de um curso de formação deva levar em consideração os anseios 
e as necessidades daqueles que integrarão o grupo participante, ou seja, faz-se necessário um diagnóstico proeminente das reais necessidades existentes tanto dos sistemas de ensino como dos professores em exercício. Diante desse processo "seus conhecimentos prévios, crenças, ideias e opiniões precisam ser de fato considerados, não só porque essa é uma postura educativa democrática, mas porque é condição para aprendizagem significativa" (BRASIL, 2002, p. 132). Sendo assim, essa premissa precisa estar engajada no planejamento dos cursos voltados para formação continuada.

Se tratando do ensino de ciências, em especial, do ensino de Geologia, Sicca et al., (2014, p. 358) aponta que o currículo da formação continuada deve abordar temas que favoreçam o "caráter sistêmico, integrado e complexo dos fenômenos terrestres". A adoção de problemáticas ambientais locais deve favorecer a articulação do ensino nesses termos, garantindo o estabelecimento de uma perspectiva em CTS.

Assim, a formação continuada em Geologia configura como uma possível oportunidade para suprir as deficiências que o professor de $\mathrm{CN}$ de áreas específicas teve durante sua formação com o tema, uma vez que de acordo com Magalhães Júnior e Pietrocola (2010), a formação atual dos professores não consegue suprir a importância e os conhecimentos de Geologia, que se encontram previstos no currículo de ciências por meio dos eixos "Terra e Universo", "Vida e Ambiente" e "Tecnologia e Sociedade" dos PCN. Permitindo, portanto, uma nova chance de assimilar, aprofundar e fixar melhor os conteúdos exigidos hoje nos currículos escolares da $\mathrm{EB}$, como compreender o pensamento geocientífico interdisciplinar.

A formação continuada que considere também atividades práticas, desde aulas laboratoriais como atividades de campo, poderá oferecer ao professor ainda a oportunidade de vivenciar a interdisciplinaridade inerente aos processos geológicos, favorecendo o desenvolvimento de suas habilidades para aplicá-la em sala de aula junto a seus alunos. Mais vantagens podem ser agregadas caso tanto os temas teóricos e práticos sejam contextualizados ao ambiente de ocupação do aluno, no caso o Distrito Federal, o que facilitará a transposição desse conhecimento na compreensão da influência antropogênica sobre um ambiente conhecido.

Partindo dessa premissa, a promoção de ações que fomentem o preenchimento de lacunas presentes no ensino, contribui plenamente para o provimento de possíveis reformas curriculares que envolvem os elementos intrínsecos à Geologia, tendo como instrumento favorecedor dessa questão a adoção da educação a distância como veículo que visa fornecer uma contribuição aos professores, no que tange a sua formação continuada. 


\subsection{Possíveis Contribuições da Educação a Distância na Formação de Professores}

Com o advento e avanço dos recursos tecnológicos e científicos, diversas mudanças tornaram-se perceptíveis na sociedade, em especial no campo educacional. A internet tem ganhado amplo destaque, permitindo o acesso a uma gama de informações, fomentando o processo de interação entre os indivíduos, mesmo que a distância. Nesse sentido, de acordo com Crespí, Gonzales e Barreno (2006, p. 54), o surgimento da internet "começou a produzir profundas mudanças nos métodos de ensino e aprendizagem e, objetos e objetivos educacionais. Permitindo dessa forma uma interpretação da informação veiculada, a fim de repensá-la sob um aspecto mais criativo". Entretanto, é importante destacar que apesar da internet ser promissora, na maioria das vezes, a qualidade da informação veiculada não pode ser assegurada. Ressalta-se então, a importância da interpretação e da seleção das informações a serem utilizadas nas bases educacionais.

Com acesso às bases da tecnologia, a educação a distância começou a ganhar espaço no que diz respeito ao fomento de cursos de graduação. No Brasil, essa modalidade de ensino possui uma curta história se tratando do fornecimento de cursos regulares, entretanto, a Lei de Diretrizes e Bases da Educação Nacional (Lei 9.394/1996) regulamenta em seu artigo 80 que o Poder Público incentivará o desenvolvimento de programas de educação a distância em todos os níveis e modalidades de ensino, e de educação continuada, sendo oferecida por instituições credenciadas pela União (BRASIL, 2005; GIOLLO, 2008).

A educação a distância apresenta distintas definições, sendo possível encontrar diversas concepções na literatura. Holmberg (1977) preconiza que essa modalidade permite que o aluno tenha contato com diversas formas de estudo, estando sob a ação e mediação de professores e tutores. Para Keegan (1991), a educação a distância consiste na separação física entre professor e aluno, sendo essa a principal premissa que a distingue do ensino presencial. Seu processo educacional origina-se mediante diálogos com encontros pontuais que visam a elucidação dos processos de socialização e didático-pedagógico. Somadas a essas concepções, o Decreto n..$^{\circ}$ 5.622, de 19 de dezembro de 2005 da LDB a define em seu artigo $1^{\circ}$ como sendo:

Uma modalidade educacional na qual a mediação didático-pedagógica nos processos de ensino e aprendizagem ocorre com a utilização de meios e tecnologias de informação e comunicação, com estudantes e professores desenvolvendo atividades educativas em lugares ou tempos diversos (BRASIL, 2005). 
Os cursos de educação a distância ocupam plena posição no que diz respeito à formação inicial de diversos profissionais da educação, entre eles biólogos, pedagogos, educadores físicos e outros. A alternância entre aulas semipresenciais e presenciais viabiliza a otimização do tempo e a articulação com outras atividades cotidianas dos estudantes. Sendo assim, a educação a distância poderá fornecer também um contributo na formação continuada dos profissionais que estão atuando no ensino de ciências, tendo em vista que essa modalidade tem ganhado visibilidade, pois acompanha os avanços do campo científico, tecnológico e da comunicação, consolidando-se assim, como uma modalidade que contribui diretamente nas bases do ensino. Conforme Pedrosa (2003):

\begin{abstract}
A educação a distância responde à proposta de um modelo pedagógico alternativo, que tem por objetivo abrir o acesso à informação aos que desejam aprender. Desde que bem direcionada e com o apoio dos meios adequados, efetivamente pode contribuir para vencer barreiras do acesso à educação, assumindo o papel de mobilizadora de estratégias que viabilizem os princípios e fins da educação permanente, por conseguinte, da formação continuada (PEDROSA, 2003, p. 9).
\end{abstract}

No que concerne aos meios utilizados para viabilização desta modalidade, o Ambiente Virtual de Aprendizagem (AVA) moodle é a ferramenta que apresenta amplo destaque, é por ele que a interação entre professor e aluno pode ser assegurada, sendo um dos recursos mais utilizados. Há que se considerar a utilização de outras mídias, tais como videoconferências, audioconferências, vídeos, televisão, rádio e internet. $\mathrm{O}$ moodle precisa conter uma interface apresentável, que seja dinâmica e dotada de operabilidade, uma vez que é essa "caixa de diálogo" que vai direcionar o trabalho do usuário. Sendo assim, um bom sistema deve exigir pouco esforço mental no ato de seu manuseio (CRESPÍ; GONZÁLEZ; BARRENO, 2006).

O AVA é o espaço em que ocorrem as trocas de conhecimento entre os alunos, professores e tutores, o estabelecimento da prática didática, a mediação pedagógica e a elucidação do processo de ensino-aprendizagem, sua utilização requer cuidados com os materiais e informações adotados para uso dos alunos. Como sugerido por Freire (1987), é necessário desprender-se de uma educação que só privilegia a plena transmissão de informações, fator esse que nada acrescenta na conduta da busca pelo saber, a informação requer caminhos que permita que o processo de aquisição do conhecimento seja amplamente lapidado.

Crespí, González e Barreno (2006, p. 55) afirmam que a participação em cursos a distância "exige o envolvimento pleno nas atividades. Fazer contribuições, responder aos pares e organizar as ideias por escrito e de forma consistente é um compromisso, um 
aprendizado real". A abordagem dos temas demanda uma estruturação que favoreça a investigação indo além da mera observação e assimilação de conteúdos, de modo que, os professores participantes utilizem as bases construídas para articular os conhecimentos em uma esfera que contemple, estimule e favoreça a aprendizagem dos estudantes.

A proposta de $\mathrm{EaD}$ para formação continuada em Geologia se justifica pela função principal intrínseca a qualquer curso a distância, a de facilitar o aprimoramento profissional em consonância com a vida já atribulada de professores da EB. A utilização de recursos multimídia via internet, hoje globalmente difundidos, vêm favorecendo o grande aumento dessa modalidade, as quais podem ser adaptadas também aos conteúdos geológicos.

Outra vantagem é o favorecimento da opção de escolha por parte do aluno de sua maneira de aprender. Quando utilizada, a plataforma apresenta abordagens variadas de um mesmo assunto. Essa possibilidade é muito favorável, do nosso ponto de vista, posto que a interdisciplinaridade da Geologia exige distintos recursos multimídias para sua explanação e diferentes tipos de raciocínio para sua compreensão (CARVALHO, 2013).

As aulas ministradas a distância poderiam levantar desconfianças quanto à qualidade de um curso de Geologia, haja vista que esta só se entende como disciplina pelo contato direto com a natureza ou com seus exemplares, como premissa defendida por vários estudiosos da área acerca das atividades práticas, que são promissoras no sentindo de desenvolver a literacia científica "mediante a observação, visualização, descrição, interpretação, análise e compreensão dos fenômenos geológicos" (COSTA, 2013, p. 6). No entanto, Signoretti e Carneiro (2014), pesquisadores em ensino de geociências, comentam que é possível o aprimoramento do ensino de Geologia pela atualização e utilização dos recursos de ensinoaprendizagem por intermédio de ambientes virtuais de comunicação e aprendizagem.

Acredita-se que para uma experiência pioneira, o planejamento de uma formação continuada a distância deve manter uma distribuição de carga horária entre conteúdos teóricos e práticos similar a carga horária que ocorre hoje nos cursos presenciais de graduação, onde a disciplina de Geologia introdutória é ministrada com $70 \%$ de aulas teóricas e 30\% de aulas práticas. A maior diferença, para a qual é possível supor tanto resultados positivos como negativos, será de que a aula prática, comum de acontecer concomitante em alguns tópicos teóricos de Geologia em cursos presenciais, como por exemplo, nos tópicos sobre tipos de rochas, não será ministrada dessa forma. Propõe-se que algumas práticas sejam agrupadas para serem apresentadas em conjunto numa única aula presencial.

A EaD pode ainda agregar uma vantagem com relação a avaliação, pois a possibilidade de datas e horários sistematizados para as atividades numa plataforma a 
distância permitem um acompanhamento mais frequente do desenvolvimento do aluno (PEREIRA; LARANJA; FIDALGO, 2012) e acaba por habilitar o professor como usuário nas Tecnologias de Informação e Comunicação (TIC) para que, caso queria usar o mesmo tipo de ferramenta em suas aulas, saiba melhor orientar seus alunos quanto ao seu uso.

Uma vez observados os limites e vantagens das propostas com EaD (PEREIRA; LARANJA; FIDALGO, 2012), propomos então a formação continuada a distância intitulada "Educação em Geologia", para professores de CN, com formação em área específica, do Distrito Federal, cuja metodologia é apresentada a seguir.

\section{CAPÍTULO 3 - METODOLOGIA}

De acordo com os objetivos propostos, a presente pesquisa apresenta-se como qualitativa uma vez que, as informações foram obtidas por meio do contato direto do pesquisador com os pesquisados e o fenômeno a ser observado; os pesquisadores possuem interessam pelo processo e pelos resultados alcançados; e busca-se compreender o significado que os sujeitos pesquisados atribuem às suas experiências (BOGDAN; BIKLEN, 1994).

Desse modo, o presente estudo caracterizou-se como uma pesquisa colaborativa (PIMENTA, 2005; ZEICHNER, 2008), visto que o interesse é desenvolver pesquisas com professores no contexto escolar e sua prática pedagógica e não sobre os docentes, buscando contribuir para o processo de formação continuada desses docentes. Desgagné (1998) ressalta que na pesquisa colaborativa é estabelecida uma parceria dual denominada institucional e relacional que gira em torno do alcance de um objetivo comum, possibilitando, desse modo, reconciliar as dimensões da pesquisa em educação, produção de saberes e a formação continuada, contribuindo, assim, para o avanço dos conhecimentos produzidos. Nesse sentido, Nunes e Ibiapina (2008), acrescentam ainda que:

\footnotetext{
A pesquisa colaborativa em contextos educacionais apresenta-se como possibilidade a negociação e tomadas de decisões em conjunto dos colaboradores a partir da compreensão da prática com a teoria, suscitando transformação de contextos, bem como das formas de ensinar/aprender e desenvolver dos indivíduos envolvidos. Ou seja, o poder docente em interpretar o saber, o saber-fazer, saber-ser (NUNES; IBIAPINA, 2008, p. 10).
}

Segundo Ibiapina (2008), este tipo de pesquisa está centrado na resolução de impasses sociais, principalmente daqueles vivenciados dentro do cotidiano escolar. Sua prática está situada em ações que estimulem a produção de conhecimentos, voltados para a mudança de 
posturas culturais e profissionais, principalmente por parte dos professores. Em suma, esta prática visa indagar a realidade, colocando seus atores à frente do contexto, a fim de promover a melhoria da qualidade do ensino e a ressignificação da didática adotada em sala de aula.

A investigação colaborativa propiciou aos professores momentos de reflexão acerca da prática docente, estabelecendo dessa forma, um elo entre a pesquisa e a profissionalização na formação continuada. A realização da construção da proposta de um curso de formação continuada, em conjunto com os professores, teve o intuito de reconhecer a necessidade de administrar sua própria formação, de acordo com as dificuldades que surgem durante a prática educativa.

\subsection{ETAPAS DA PESQUISA}

Com a finalidade de alcançar os objetivos da pesquisa, as seguintes intervenções foram realizadas: a) seleção dos sujeitos de pesquisa: entrega do Termo de Consentimento Livre e Esclarecido (TCLE) aos participantes (ver apêndice A); b) entrevista inicial individual semi-estruturada (ver apêndice B) realizada com professores que possuíam interesse em participar da ação proposta; c) estudo: análise das entrevistas; d) elaboração da proposição educativa - curso de formação continuada a distância; e) aplicação: realização do curso, etapas a distância e presencial; f) avaliação: entrevista individual semi-estruturada (ver apêndice C) com os participantes do curso, importância da ação para a formação dos professores no que diz respeito ao ensino de Geologia.

\subsubsection{Seleção dos sujeitos de pesquisa}

Participaram da pesquisa 15 professores de Ciências Naturais, atuantes no Ensino Fundamental. Assim, foram selecionados professores de escolas de uma cidade satélite do Distrito Federal. A escolha dos participantes ocorreu em virtude da formação acadêmica, abarcando profissionais que lecionam na disciplina de Ciências Naturais, considerando que o estudo visou fornecer uma complementação na formação dos profissionais dessa área.

A escolha do público alvo pode ser justificada pela formação inicial, interesse e disponibilidade que foi apresentada pelos professores em participar da presente ação 
colaborativa. Além do que, conforme os Parâmetros Curriculares Nacionais/Ciências Naturais (BRASIL, 1998) é durante o $\mathrm{EF}$, no $6^{\circ}$ ano $/ 5^{\mathrm{a}}$ série, que os educandos e docentes possuem mais contato com temas que são pertinentes a área do ensino de Geologia, tais como Universo, Sistema Solar, Planeta Terra e outros.

\subsubsection{Entrevistas semiestruturadas}

Para o presente estudo, foi adotada a entrevista qualitativa uma vez que, essa "fornece dados básicos para o desenvolvimento e a compreensão das relações entre os atores sociais e sua situação" (GASKELL, 2002, p. 64). Sendo assim, empregamos a entrevista individual semiestruturada que, segundo Manzini (2004), está centrada em um tema a partir do qual construímos perguntas fundamentais, acrescentadas por outras, de acordo com a necessidade, durante a entrevista. De acordo com Laville e Dionne (1999, p. 333), a entrevista semiestruturada consiste em uma "série de perguntas abertas feitas oralmente em uma ordem prevista, mas na qual o entrevistador tem a possibilidade de acrescentar questões de esclarecimento". A escolha por este tipo de estratégia de coleta de dados deu-se pela flexibilidade que esta apresenta no ato da conversa, permitindo ao pesquisador coletar a informação com uma maior riqueza de detalhes, e aos entrevistados empoderamento na fala.

A utilização da entrevista semiestruturada leva em consideração a construção do tópico guia que é fundamentado mediante a leitura crítica da literatura apropriada, envolvendo o objeto de estudo, reconhecimento do campo e os objetivos que se busca alcançar com a pesquisa. Este deverá ser um mecanismo de orientação ao entrevistador, um documento que deverá trazer os temas centrais e os problemas de pesquisa a serem investigados (GASKELL, 2002).

Para a entrevista inicial o roteiro focalizou os seguintes aspectos: a) formação acadêmica dos professores; b) tempo de experiência como docente na Secretaria de Educação e/ou outras Unidades de Ensino da EB; c) disciplina de Geologia na grade curricular da graduação; d) aspectos da disciplina cursada durante a graduação; e) importância da compreensão da dinâmica do planeta Terra na resolução de problemas socioambientais; f) dificuldade e/ou facilidades ao trabalhar temas de Geologia nas aulas; g) estratégias de ensino utilizadas para trabalhar temas da Geologia; h) recursos didáticos utilizados para trabalhar temas de Geologia; e i) familiarização com os recursos tecnológicos. Participaram desta 
primeira entrevista 15 professores, dentre eles, três professores da rede particular de ensino, e uma que não possuía experiência docente.

Para a entrevista avaliativa o roteiro abordou os seguintes itens: a) importância dos cursos de formação continuada; b) expectativas em relação a proposta executada; c) base interdisciplinar e ambiental no que concerne a Geologia; d) percepção acerca da metodologia adotada; e) prática em EaD e f) postura dos participantes envolvidos na ação pedagógica. Participaram desta última etapa da entrevista 9 professores, os concluintes da ação desenvolvida, ou seja, os professores que finalizaram sua participação no curso de formação continuada oferecido.

As entrevistas foram realizadas em encontros presenciais marcados previamente com os participantes e, inicialmente foi entregue o TCLE. Este tinha como objetivo esclarecer alguns aspectos gerais sobre a pesquisa, salientando seus objetivos e intenções, além de ressaltar que a participação no referido estudo é voluntária, ou seja, o/a participante poderia desistir a qualquer momento. A entrevista se fez em dois momentos, no primeiro participaram 15 professores e no segundo momento 9 professores.

\subsubsection{Análise das entrevistas}

A análise qualitativa dos dados "visa, sobretudo, gerar um conhecimento mais aprofundado de um fenômeno, as dimensões complexas de um problema ou tema, envolvendo um número restrito de participantes [...]” (BARBATTO, 2008, p. 16). Lüdke e André (1986, p. 45) acrescentam ainda que a "análise de dados qualitativos significa trabalhar com todo o material obtido durante a pesquisa, que incluem os relatos de observação, as transcrições das entrevistas, as análises de documentos, entre outras informações disponíveis”.

Neste estudo as entrevistas (inicial e avaliativa) foram gravadas, transcritas, as falas foram organizadas e sistematizadas de modo a agrupar os conteúdos mais análogos em categorias que visaram "aproximar respostas semelhantes, complementares e divergentes de modo a identificar recorrências, concordâncias, contradições, etc” (DUARTE, 2004, p. 222).

As categorias foram formuladas com base na integração dos objetivos e nas inferências teóricas e conceituais presentes em cada questão (DUARTE, 2004). Sendo assim, para elucidação dos resultados não foram selecionadas todas as respostas para análise, uma vez que, se buscou identificar concepções similares sendo destacada para discussão aquela 
fala que fosse mais representativa em relação às respostas evidenciadas pelos demais participantes.

\subsection{PROPOSIÇÃO DE INTERVENÇÃO EDUCATIVA}

Após a realização da entrevista inicial, partiu-se para a construção da proposta educativa (ver apêndice D), esta que esteve pautada nas concepções obtidas com a entrevista, servindo de base para a construção do curso de formação continuada em conjunto com os participantes, neste caso os professores.

O presente curso de formação continuada, com vistas à capacitação dos docentes envolvidos, teve início no dia 15 de setembro de 2015 e término no dia 15 de outubro de 2015, com duração de 60 horas, distribuídas em encontros virtuais e presenciais, sendo 48h on line (12 horas por semana) voltadas para o desenvolvimento dos trabalhos, leituras, participação nos fóruns e realização das atividades propostas e $12 \mathrm{~h}$ presenciais organizadas em três encontros (4 horas cada encontro).

A presente proposta buscou realizar uma mediação dos conceitos geológicos, por intermédio de um curso de formação continuada, visando: fornecer uma complementação dos conhecimentos intrínsecos ao estudo da Geologia; favorecer a abordagem interdisciplinar dos saberes com outras áreas do ensino; favorecer a perspectiva ambiental e contribuir para a realização de uma mediação coesa e linear dos temas geocientíficos trabalhados nas aulas de Ciências Naturais.

A proposição educativa foi pensada e construída com base nas percepções lançadas pelos professores, na dificuldade em encontrar recursos e/ou materiais didáticos em websites, na escassez de materiais disponibilizados nas instituições de ensino do qual os participantes integram e também na busca pela viabilização do tempo. Buscou-se assim, alavancar a formação desses profissionais, levando em consideração seus limites, oportunizando o gerenciamento dos mecanismos de aprendizagem e autonomia frente ao processo de ensino.

Diante de tais prospecções a proposição educativa foi estruturada e aplicada, adotando-se a modalidade de educação a distância, utilizando para sua execução a ferramenta do AVA, com o intuito de viabilizar a participação dos profissionais envolvidos, além de favorecer a reflexão e a ação frente à prática e a qualificação profissional.

O ambiente virtual de aprendizagem AVA, foi composto por materiais didáticos básicos, tais como vídeos, imagens, animações, softwares, bibliografias de livros, textos-base, 
de autoria de pesquisadores e estudiosos da área do ensino de geociências, disponíveis em diversos websites, como, por exemplo, da Universidade de São Paulo (USP), Universidade Federal do Rio Grande do Sul (UFRGS), Universidade de Brasília (UnB), entre outros. Para a seleção dos recursos inseridos na plataforma foram consideradas as necessidades dos estudantes e professores que se beneficiaram do curso, tendo como destaque a base a) sociocultural, explorando o contexto em que tanto alunos, como professores estivessem inseridos; b) socioeconômica, adotando-se materiais de baixo custo para a execução das atividades; c) contato com a tecnologia, levando os profissionais a expandir seus conhecimentos em relação às TIC e d) a preparação para novos modelos de aprendizagem, visando fornecer mecanismos para que o professor possa atrelar os temas de Geologia às estratégias pedagógicas a serem empregadas em momentos posteriores nas aulas de Ciências Naturais.

Após a seleção dos recursos e com as atividades previamente montadas, foi enviado aos professores da programação do curso um esboço por $e$-mail, no qual foram elencados os temas e as sugestões de atividades fornecidas pelos mesmos durante a etapa da entrevista inicial. Desse modo, a proposta foi ganhando forma e a abordagem dos temas foi organizada em trios, sem desconsiderar a escala temporal, interdisciplinar e conceitual que pode ser observada dentro dos principais assuntos da Geologia.

O material intitulado: "Educação em Geologia" foi montado em documento word e foi lançado na plataforma aprender.unb.br de acordo com o cronograma estabelecido para o desenvolvimento do curso. Os links dos recursos utilizados foram disponibilizados aos participantes, bem como o acesso aos softwares, textos e imagens. Os temas abordados foram: Formação do planeta Terra, Sistema Solar e Tempo Geológico; Minerais, Rochas e Solos; Tectônica de Placas, Relevo e Ciclo Hidrológico.

\section{CAPÍTULO 4 - RESULTADOS E DISCUSSÃO}

Neste capítulo são apresentados os resultados da pesquisa, sendo realizada a discussão dos dados coletados nas entrevistas (inicial e avaliativa) à luz do referencial teórico. Sendo este capítulo subdividido em quatro tópicos, nos quais constam: perfil dos professores de Ciências Naturais; aplicação da proposição educativa desenvolvida e elaborada nesta dissertação; percepção dos participantes acerca proposição desenvolvida e por fim uma breve 
reflexão sobre o contributo desencadeado pela formação continuada na profissão docente e os aspectos promissores do curso "Educação em Geologia".

A transcrição das entrevistas resultou em uma grande quantidade de informações relevantes para a presente investigação. Essas informações foram elencadas em categorias que visaram relacionar os dados coletados com as concepções discutidas à luz do referencial teórico. Desse modo, enfatiza-se mais uma vez que, dos dados coletados foram selecionados para discussão as concepções mais representativas em relação às falas fornecidas durante a realização das entrevistas pelos participantes da pesquisa.

\subsection{PERFIL DOS PROFESSORES DE CIÊNCIAS NATURAIS}

Para este primeiro tópico do estudo foram realizadas entrevistas que possuíam o intuito de averiguar as percepções dos professores acerca da Geologia, tanto em sua formação inicial como em sua prática pedagógica cotidiana.

Desse modo, os dados obtidos foram organizados de acordo com as seguintes categorias: 1) Caraterização dos sujeitos de pesquisa 2) Contato com disciplinas da Geologia; 3) Importância da compreensão da dinâmica do planeta Terra na resolução de problemas socioambientais; 4) Dificuldades e/ou facilidades ao trabalhar temas de Geologia nas aulas; 5) Estratégias de ensino e recursos didáticos utilizados para trabalhar temas da Geologia.

\subsubsection{Caracterização dos sujeitos de pesquisa}

Por meio da realização da entrevista semi-estruturada inicial traçamos o perfil dos professores que participaram desta investigação. O nome dos entrevistados foi substituído por nomes fictícios visando, desse modo, preservar a identidade de cada participante. Os nomes escolhidos foram nomes de minerais tendo em vista que o foco desta investigação é o ensino de Geologia.

- Azurita: professora, 33 anos. É licenciada em Ciências Naturais e Matemática, com especialização em ensino de Biologia. Possui 15 anos de experiência na Secretaria de Estado de Educação do Distrito Federal (SEEDF). Trabalhando com todas as séries e anos do Ensino Fundamental. 
- Apatita: professora, 24 anos. É licenciada em Ciências Naturais. Possui 3 anos de experiência na SEEDF, atuando em turmas do $6^{\circ}$ e $7^{\circ}$ ano e, atualmente está concluindo o curso de Pedagogia.

- Barita: professora, 32 anos. É licenciada em Química. Possui 6 anos de experiência na SEEDF com todas as séries e anos do Ensino Fundamental e 1 ano na rede particular de ensino

- Berilo: professor, 32 anos. É licenciado em Ciências Biológicas, possui pós-graduação em gestão ambiental, ordenamento setorial, avaliação de impacto ambiental, ciências ambientais. Possui 17 anos de experiência na rede particular de ensino, atuando em turmas do Ensino Fundamental e médio.

- Fluorita: professora, 23 anos. É licenciada em Ciências Naturais e atualmente faz parte do corpo discente do Mestrado Profissional em Ensino de Ciências da UnB. Possui 4 anos de experiência na SEEDF, sendo que desses 4 anos, 3 foram atuando em projetos desenvolvidos nas escolas públicas em parceria com a UnB.

- Galena: professora, 28 anos. É licenciada em Ciências Naturais. Possui 1 ano de experiência na SEEDF, atuando com turmas do $9^{\circ}$ ano do Ensino Fundamental e atualmente está cursando Pedagogia.

- Halita: professora, 23 anos. É licenciada em Ciências Naturais. Possui 1 ano de experiência na SEEDF, atuando em turmas do $6^{\circ}$ ano do Ensino Fundamental e atualmente faz parte do corpo discente do Mestrado Profissional em Ensino de Ciências da UnB.

- Hematita: professora, 24 anos. É licenciada em Ciências Naturais. Possui 6 meses de experiência na SEEDF, atuando em turmas do $8^{\circ}$ e $9^{\circ}$ ano do Ensino Fundamental.

- Lazulita: professora, 31 anos. É licenciada em Geografia. Possui 1 ano de experiência na SEEDF, especialmente com turmas do $6^{\circ}$ ano do Ensino Fundamental e, em anos anteriores trabalhou na rede privada de ensino com turmas do Ensino Fundamental ao médio.

- Malaquita: professora, 38 anos. É licenciada em Biologia e Pedagogia. Possui 1 ano de experiência na SEEDF, atuando em turmas do $6^{\circ}$ e $7^{\circ}$ ano do Ensino Fundamental.

- $\underline{\text { Paládio: }}$ professor, 26 anos. É licenciado em Ciências Naturais. Atualmente faz parte do corpo discente do Mestrado Profissional em Ensino de Ciências da UnB. Possui 8 meses de experiência na rede particular de ensino com turmas do Ensino Fundamental e médio. 
- Pirita: professora, 52 anos. É licenciada em Ciências Naturais e Matemática e fez complementação em Ciências Naturais pela UnB. Possui 18 anos de experiência atuando em todos os anos do Ensino Fundamental.

- Quartzo: professora, 40 anos. É licenciada em Biologia, possui especialização em mamíferos e em educação ambiental. Possui 9 anos de experiência, sendo 2 na SEEDF e os demais na rede particular de ensino, atuando em todos os anos do Ensino Fundamental.

- Siderita: professora, 26 anos. É licenciada em Ciências Naturais. Possui 3 anos de experiência atuando no $6^{\circ}$ e $9^{\circ}$ ano do Ensino Fundamental.

- Turquesa: professora, 26 anos. É licenciada em Ciências Naturais. Possui experiência de 3 anos no Ensino Fundamental por meio de projetos desenvolvidos na parceria entre Universidade e escola.

\subsubsection{Contato com Disciplinas da Geologia}

A entrevista iniciou-se averiguando aspectos relacionados à formação inicial dos docentes no que diz respeito ao contato com disciplinas que abordassem temas de ordem geológica, enfatizando o estudo da Terra e a características dos seus processos sistêmicos. Os professores destacaram que tiveram pouco contato com disciplinas de Geologia durante a graduação e que as mesmas tinham em sua maioria aulas teóricas e poucas aulas práticas.

O estudo da formação primordial de cada professor sugere a coleta dos conhecimentos prévios frente ao tema trabalhado na ação colaborativa, bem como as necessidades relacionadas a este algoritmo. De acordo com Ibiapina (2008, p. 41), essa averiguação torna-se necessária, pois leva "os participantes a expor os temas de interesse formativo e as sugestões para o preenchimento das lacunas deixadas no decorrer do processo de formação, permitindo que estes possam ser retomados em outras etapas da formação".

Mediante aos relatos foi possível apreender que o contato com a Geologia durante a graduação em sua maioria se restringia a uma, ou até mesmo no máximo duas disciplinas, o que não possibilita a compreensão sequenciada da história geológica, integrada ao surgimento dos seres vivos e seu processo evolutivo. Essa questão fica evidente com a fala dos professores participantes da pesquisa, no qual os mesmos expõem a quantidade de disciplinas cursadas e as características das mesmas: 
"Na verdade, assim, eu só tive uma disciplina, denominada Geologia Geral, ela tinha um aspecto mais... teórico do que prático, na verdade a gente fez duas viagens [...] uma pra... analisar, pesquisar e teve uma outra que eu também não lembro bem, a gente passou em algumas cavernas, foi em Ouro Preto, né? A gente viu muita coisa lá, já tem muito tempo e eu não lembro muito [...] mas eu sei que a gente teve essa parte prática também" (AZURITA).

"Durante a graduação eu cursei uma disciplina que se chamava Fundamentos da História da Terra, FHC, na verdade eu só a fiz porque era obrigatória, mas não porque eu apresentava interesse naquele dado momento, até porque eu direcionei meu curso para outra área de pesquisa, e não tive interesse de buscar disciplinas optativas na área de Geologia [...] essa disciplina que eu mencionei, tinha um caráter mais teórico do que prático, era mais um geralzão da 'Geologia' em si” (APATITA).

"Eu fiz Geologia Geral e Ciências da Terra?... Esqueci o nome da matéria, mas foi alguma coisa por aí, lembro que foram duas matérias. Uma era bem teórica. Geologia Geral era mais experimental e Ensino Geociências também, era bem prático" (GALENA).

Esse contato mínimo, desencadeado ao longo do processo de formação desses professores não é o suficiente para o entendimento dos aspectos físicos, químicos, biológicos dos processos geológicos, e nem da "escala de tempo desde a origem do planeta, limitando a compreensão da real dimensão da dinâmica natural” (TOLEDO, 2005, p. 43).

Além do que, ficam evidentes as necessidades que são sentidas ao relatarem acerca da característica de cada disciplina, apesar de algumas aulas práticas esporádicas, a necessidade da compreensão dos fenômenos científicos esbarra no conjunto de aspirações formativas individuais que, no contexto atual, requer do professor um nível de conhecimento mais sistemático atrelado às proeminentes questões sociais e ambientais, que permita a condução da docência em um caráter mais profissional (IBIAPINA, 2008).

Os participantes foram indagados ainda acerca do contato estabelecido com a Geologia em outros momentos fora da graduação. Como é o caso de Barita, Azurita e Siderita que explicitaram que o contato com a Geologia se deu somente durante a prática pedagógica:

“Quando lecionei nas turmas de Química do Ensino Médio, tive a oportunidade de trabalhar a tabela periódica associando ela aos minerais, aí claro que foi uma relação superficial, mais foi durante esses momentos que eu comecei a pesquisar e aprender sobre Geologia [...] aí no começo foi difícil, mais os alunos achavam um barato, também vi que na escola tinham alguns exemplares de minerais [...] daí durante três anos, trabalhei com essa prática em sala de aula" (BARITA). 


\footnotetext{
"Em sala de aula, no duro, ali na prática pedagógica mesmo (risos) porque durante o curso, que eu me lembre eu estudei um pouco sobre rochas e não tive Geologia no meu curso" (AZURITA).

"No primeiro ano que eu trabalhei o conteúdo de quinta série, é... de solo, rocha, ciclo das rochas, e... aquela parte de Universo, formação do planeta Terra, tudo isso aí, tudo que é conteúdo de quinta série” (SIDERITA).
}

Nas falas acima é perceptível o quanto a limitada e fragmentada concepção de Geologia não capacita os professores a desenvolverem de forma sistêmica, hipotética e temporal, a desejável integração que se espera dos conteúdos na referida área (GONÇALVES; SICCA, 2005).

Pela fala de Barita, percebe-se que os temas de Geologia quando abordados e explorados em suas reais características, enquanto ciência interdisciplinar e interpretativa torna possível aos estudantes desenvolver a curiosidade, o que contribui para a construção do raciocínio sobre os constituintes mais básicos que envolvem o estudo da Terra, tais como sua organização, a dinâmica dos sistemas naturais e a aquisição de competências específicas e transversais, daí nota-se a importância da sua aprendizagem e do seu desenvolvimento nas esferas da cognição (BOLACHA, 2008).

É nesse contexto que a observância de uma formação inicial incipiente remota a necessidade de ampliar a formação permanente e não apenas de expandir uma formação inicial repleta de carências. Isso se deve prioritariamente a realidade prática que o professor precisa vivenciar frente aquilo que ele vai se deparar, para então ser capaz de propor ações que sejam, no mínimo, capazes de estabelecer soluções que conduzam um trabalho em equipe, que objetive a melhoria direta no ensino de ciências (CARVALHO; GIL-PÉREZ, 2011).

\subsubsection{Importância da compreensão da dinâmica do planeta Terra na resolução de problemas socioambientais}

Acerca da importância do conhecimento geocientífico para resolução de impasses ambientais que emergem cotidianamente na sociedade, quando indagados, os professores em 
sua maioria, reconheceram a importância do entendimento da dinâmica terrestre para minimizar as problemáticas ambientais, conforme ficou evidenciado nas seguintes falas:

\begin{abstract}
"Ah eu acho isso assim, principalmente pro nosso estudante, né? Quando a gente começa a demonstrar pra ele um todo pra chegar nas partes é muito mais fácil, quando você demonstra pra eles hoje, os impactos que o planeta vem principalmente sofrendo e, demonstrando pra eles que tudo isso é devido a ação humana, eles começam a analisar melhor. A reportagem que você traz por exemplo no começo do Rio de Janeiro, das casas que tem a falta de mata ciliar, mata ciliar não, perdão, da cobertura vegetal, que aí a gente vê justamente as erosões, aquelas casas desbarrancando morro abaixo, então a gente realmente demonstra pra eles, que o nosso papel social, por mais que eu esteja num lugar que não tenha nada disso, eu vou tá influenciando de alguma forma, até no meu consumo né? Se eu souber realmente o que consumir, eu vou degradar menos o meio ambiente. Só que isso pra eles é muito vago, né? Na hora que você pega um experimento pra mostrar pra eles um local que pode tá tendo erosão, que ele pode produzir essa erosão, é totalmente diferente né? E aí o aluno começa a ter percepção [...] ai sim ele para pra pensar: poxa prof. é mesmo" (QUARTZO).

“Total importância! Você tem que saber como que o planeta funciona, pra saber como que você vai lidar com ele, porque senão, como é que você vai cuidar, como você vai entender, até pra entender o porquê que está assim hoje, a gente tem que saber como é que funciona, como é que começou tudo" (SIDERITA).
\end{abstract}

Em sua maioria, as problemáticas ambientais são frutos da ação do homem, e para construção de uma relação saudável com as esferas do planeta, torna-se necessário compreender que a preservação dos recursos naturais do planeta é essencial para a subsistência de todo ser vivo que habita a Terra.

A fala de Quartzo ilustra a importância de demonstrar aos estudantes que todos os indivíduos exercem um papel fundamental e indispensável perante a sociedade, seja qual meio estiver em questão. Muitas das problemáticas ambientais existentes atualmente são resquícios e resultados de ações mal pensadas, sustentadas por interesses financeiros e/ou próprios. Ao se trabalhar a perspectiva crítica em sala de aula, o professor leva o aluno a interpretar os fatos, passando a adotar um papel de agente, visando levar este a propor soluções para as causas mais proeminentes. Neste sentido Charpak (1996), explicita que é somente com o contato de fenômenos reais, mediante a um estudo minucioso dos fatos, que será possível modificar em profundidade a percepção das questões, de modo que seja possível evoluir os 
conceitos, indo em busca de ações que fomentem a tomada de decisões sólidas, inerentes a sustentabilidade.

Já Siderita aponta a importância do conhecimento com base na história da ciência, segundo ela para compreender o que existe atualmente na Terra, é necessário conhecer o seu funcionamento no passado. Fato evidenciado por Faria (2014) quando este ilustra uma das teorias mais utilizadas para o estabelecimento do pensamento geológico, o atualismo. Ao enfatizar em sua resposta a importância do funcionamento do planeta, a docente explora a premissa de interpretar o ambiente atual com vistas à compreensão dos fatos ocorridos no passado, passíveis de acontecer novamente no futuro planetário.

Potapova (1968) acrescenta que esse é um dos elementos indispensáveis para o entendimento da evolução do planeta Terra ao longo dos bilhões de anos, uma vez que esse fator implica na compreensão da história da Terra se baseando nas demais ciências, como também nas condições a que o planeta esteve submetido nos eventos pretéritos.

O impacto dessas descobertas para a realização das interpretações frente ao planeta Terra sugere como se encontra o seu sistema atual, bem como a importância da discussão das causas ambientais a qual o planeta encontra-se sujeito, tais como efeito estufa, aumento da temperatura global, falta de água, dentre outras.

As concepções enaltecidas por Apatita e Pirita também evocam para a adoção de um papel responsável e comprometido com as questões ambientais:

"Eu acho que é essencial, porque o aluno tem que ter conhecimento pra que ele possa intervir em algumas coisas, principalmente relacionado ao meio ambiente, ele não tem esse conhecimento que as ações que ele tá tomando no dia-a-dia pode interferir no funcionamento do planeta, então é essencial que ele tenha esse conhecimento prévio para que ele possa interferir positivamente em seu papel como cidadão" (APATITA).

"Porque tudo tá interligado, se você pensar na água, você tem que pensar na água no geral, às vezes a pessoa pensa assim: ah eu tenho que preservar a água, mas aí eu fecho a torneira da minha casa, mas eu jogo lixo no lugar errado, entendeu? Então as coisas elas são interligas, a gente precisa despertar essa consciência nas pessoas, de que o planeta ele é um sistema que é interligado e a gente precisa ter essa consciência, então assim, eu acho que nesse ponto a Geologia casa bem” (PIRITA).

A construção de uma politica voltada para a sustentabilidade deve começar desde cedo, as crianças - futuros e atuais atores sociais - necessitam aprender o significado do gerenciamento do planeta em prol do bem comum, da preservação e da minimização das 
práticas abusivas contra a natureza. Entretanto, nem sempre essa perspectiva acontece no seio familiar, ficando a cargo da escola a missão de promover um olhar sustentável em relação ao dinamismo planetário e a tudo o que é inerente a ele.

De acordo com Silva (2009), o ser humano não possui sensibilidade diante das causas ambientais e não compreende a interferência realizada no meio ambiente, este que se apropria dos recursos naturais e minerais, pouco se preocupando com a renovação de suas fontes ou com as consequências que a ocupação indevida de espaços geográficos pode ocasionar. Esse é o entendimento que veicula em grande parte da sociedade, sendo passada também de geração para geração. Dessa forma Gadotti (2009), acrescenta que o desafio atual está em quebrar o pensamento egocêntrico, em desfavorecer a visão utilitarista que as pessoas possuem frente às questões ambientais, enfatizando a importância em se promover um ensino mais preocupado e favorecedor da criticidade e reflexão nas bases educacionais.

A fala de Pirita aponta para uma questão muito promissora se tratando da Geologia, segundo esta, torna-se imprescindível desenvolver uma consciência ambiental e planetária nos indivíduos, haja vista que o planeta é um sistema interligado. Conforme apontado por Carneiro et al., (2005, p. 11), isso exige um "tratamento interdisciplinar dos problemas e, ao mesmo tempo, aprofundamento dos estudos em cada área do conhecimento".

No contexto educacional, o estabelecimento de uma educação planetária e ao mesmo tempo ambiental requer a elucidação de processos que desenvolvam e agucem o senso crítico dos alunos, tendo como primazia educar para o despertar de uma sociedade que se encontra imersa em problemáticas socioambientais e, que está a espera de um olhar embasado em concepções mais humanistas, além da compreensão de que a vida é consequência da história da Terra e que o ser humano relaciona-se diretamente com a natureza (GADOTTI, 2009; MORIN; CIURANA; MOTTA, 2003; POTAPOVA, 1968).

\subsubsection{Dificuldade e/ou facilidades ao trabalhar temas de Geologia nas aulas}

Quando questionados acerca das dificuldades e/ou facilidades que possuem ao abordar temáticas de Geologia nas aulas, os professores fizeram as seguintes considerações: 
falta de recurso da escola, é sempre uma dificuldade, não só pra área de Geologia, mas qualquer uma, a falta de recursos. Não tem laboratório não tem material então é sempre uma dificuldade grande em relação a isso, pra mim a pior de todas é isso" (SIDERITA).

"O que dificulta, por exemplo, agora eu tô trabalhando como os meninos do PIBID né? Então assim, como eles estão comigo, agora praticamente nós somos quatro professores na sala de aula, porque tem três alunos junto comigo, então assim, aí a gente senta prepara a aula faz os slides, tem uma dinâmica maior, enquanto um tá explicado o outro tá olhando os alunos. E quando você trabalha só, o que dificulta é você não ter um espaço próprio pra aquela aula, você precisa sabe, ter que ficando mudando de sala, então até você montar o data show, pra passar, tudo isso dificulta sabe [...]. A facilidade é a compreensão, por exemplo, eu fiz um quebra cabeça pros meninos das placas tectônicas, né? [...] então isso facilitou muito, os meninos, eles têm uma noção maior quando a gente trabalha o concreto né? então eles começam a entender como funciona o centro da Terra, que eles têm uma visão diferente, por causa dos filmes que passam né [...] porque são coisas que a gente não vive, não tem acesso, é praticamente abstrata. Mas aí quando você começa a trabalhar o conteúdo, a mostrar um exemplo, ficou mais fácil, mais concreto, mais fácil de trabalhar e entender o centro da Terra daquela forma. É lógico que eles têm dificuldades, se você falar pra eles assim, que o homem falou que lá no centro da Terra uma parte é sólida e a outra é líquida sendo que o homem nunca foi lá, né? Então assim eles tem essas dificuldades, mas dá pra gente trabalhar" (PIRITA).

Pela fala de Siderita e Pirita, observa-se que na maioria dos casos, a dificuldade em trabalhar determinado assunto em sala, se deve a falta de recursos materiais provenientes da própria escola. De acordo com Fazenda (1998), o primeiro passo para uma rápida minimização dessa questão consiste em exercitar nossa vontade para um olhar mais comprometido e atento às práticas pedagógicas rotineiras, que elas sejam menos pretensiosas e que o professor seja capaz de utilizar e exercer com competência no ensino, munido das ferramentas que este tem em mão, observando que, atividades simples, também são percussoras de descobertas importantes.

Pirita também chama atenção ao enfatizar uma das características mais proeminentes no ensino de Geologia, a de ser uma ciência abstrata, que necessita de um acompanhamento lógico e concreto para vislumbrar o entendimento da história e do processo evolutivo do planeta Terra. Talvez este seja um dos pontos mais centrais dentro do estudo da Geologia, compreender que é por meio da história evolutiva que o entendimento perante todas as outras coisas poderá ser alcançada e que, a observação e a interpretação diante dos fatos e 
fenômenos são essenciais para a construção do raciocínio geológico (FRODEMAN, 2010). Matthews (1990) enseja essa questão quando aponta que um dos papeis de desempenhar a história da ciência, consiste em tornar possível a compreensão profunda da matéria estudada e da própria natureza da ciência.

Conforme exposto por Delizoicov, Angotti e Pernambuco (2011, p. 15), ser professor "requer saberes e conhecimentos científicos, pedagógicos, educacionais, sensibilidade, indagação teórica, e criatividade para encarar situações ambíguas, incertas, conflituosas”. Dentro desse contexto, quanto mais o profissional assume sua postura e percebe suas razões, mais ele se torna capaz de buscar mudanças para reverter a situação instaurada no ensino, estejam elas relacionadas a alguma dificuldade com determinado saber ou determinada estratégia metodológica (FREIRE, 1987).

Os demais professores participantes da pesquisa afirmaram possuir dificuldade em trabalhar temas de Geologia nas aulas, e expuseram a limitação em sua abordagem, conforme salientado nas seguintes falas:

\footnotetext{
"Então, como eu falei, eu só tive uma disciplina durante a graduação, então eu me sinto defasada, então eu sinto muita dificuldade em transmitir esse conteúdo, eu tenho que estudar [...] eu acho que tendo uma formação continuada com esse tema, seria importante pra mim, já que a minha formação foi restrita e não contemplou tanto a Geologia" (APATITA).
}

“Ah a dificuldade mesmo é em relação a ser abstrato né? Todo conteúdo de ciências tem esse lado abstrato, mais com a utilização de recurso a gente consegue minimizar e ajuda bastante" (HEMATITA).

Pela fala da professora Apatita fica evidente que a profissional sente a necessidade de um curso de formação na área de Geologia. A maioria dos professores deseja buscar melhorias em relação aos novos conhecimentos. A formação continuada é um caminho para o alcance dessa premissa, esta deve fornecer alternativas "como resposta às necessidades reais dos professores de acordo com a perspectiva de educação permanente e, ainda, promover, apoiar e incentivar as iniciativas pedagógicas das escolas e dos professores" (GONÇALVES, 1992, p. 168).

Já Hematita levanta a questão de que a Geologia é uma ciência muito abstrata, conforme levantado por Faria (2014), seu estudo necessita do estabelecimento de relações e semelhanças desencadeadas pela Terra no passado e presente. Desse modo, enfatiza-se a importância da visão atualista nas bases do ensino geológico (FARIA, 2014). Logo, se torna necessário que o professor tome conhecimento do que a matéria significa para o aluno e para 
a realidade, a fim de promover uma visão íntegra dos processos da ciência, sendo esta acessível e de interesse dos estudantes (PIAGET, 1969).

A fala de Fluorita exprime a relação da Geologia com a falta de recursos pedagógicos:

\footnotetext{
"Bom, eu tenho muita dificuldade em Geologia né? eu não sei se é um problema já prévio que vem lá desde do ensino básico sabe? Daí acabo seguindo só o livro didático, eu acho que não consigo me interessar muito pelo tema, apesar, porque eu acho que é muito conceito, muito teoria, no contexto escolar fica muito complicado de trabalhar, não tem um laboratório que seja utilizável, você não tem a possibilidade de levar os alunos para fazer uma saída de campo num lugar que seja bacana, não tem essa autonomia pra trabalhar no ensino básico” (FLUORITA).
}

O que ocorre, em muitos dos casos, é a escassez dos recursos que são disponibilizados ao professor para que este possa desenvolver uma aula mais atrativa, que configure numa compreensão mais coesa dos temas de Geologia. Sendo assim, todos os trabalhos exprimem uma carência do conhecimento científico em si, "o que leva o professor a ser um transmissor mecânico dos conteúdos do livro de texto" (CARVALHO; GIL-PERÉZ, 2011, p. 22). Compiani (2005, p. 32) enaltece que "as aulas tradicionais e o livro didático predominantes nas escolas são descontextualizados e centrados no enciclopedismo das definições. Ensinamse repertórios e definições [...]". Entretanto, ao se tratar do ensino de Geologia, é possível perceber que os livros de Ciências, não são carregados de definições, mas sim de uma linguagem geocientífica pouco adaptada e com conteúdos que não possuem uma correlação entre si, e nem com a realidade vivenciada pelos alunos.

Barita enfatizou que a facilidade em se trabalhar temas de Geologia está na articulação dos fatos com a realidade dos alunos, de modo que seja possível relacionar problemáticas ambientais com assuntos mais proeminentes do ensino.

“Como eu já disse, nos jornais, nas revistas é possível acompanhar vários problemas ambientais, isso facilita, os alunos podem fazer alguma articulação com o tema, né? Outra facilidade é levar os alunos pra campo, pra explorar o ambiente, com a Geologia isso se torna possível, ela pode ser uma matéria prática” (BARITA).

Além disso, é perceptível ainda em sua fala a importância de atividades de campo, de acordo com Silva, Machado e Tunes (2010, p. 256), "a visita permite o levantamento da aplicação do conhecimento, criando a oportunidade de explorar e aprofundar o conteúdo e desenvolver o senso crítico nos alunos".

Pelas falas de Lazulita e Berilo, fica perceptível a importância do entendimento da Geologia na base interdisciplinar e integrada, no qual o conhecimento para ser compreendido, 
não precisa ser dividido, mas sim unificado e observado sob diferentes ângulos dentro da Ciência, fato este evidenciado por Toledo (2005), quando esta aponta que os temas de Geologia poderiam ser organizados, de forma que possibilitassem a formação de uma ideia da história Terra integrada à história da vida.

“[...] Eu gosto de trabalhar a Geologia, porque a partir da Geologia é possível essa questão da aproximação, né? [...] dessa dicotomia entre humanas e exatas, para que não haja essa separação, pro aluno perceber que não existe uma separação, é o social com o físico, na verdade é uma interação né? Quebrar, romper essa questão da dicotomia como eu falei né? De que humanas é separada das exatas, na verdade essa separação não existe, né" (LAZULITA).

"Normalmente, quando trabalhamos a Geologia, é só no sexto ano, e a maior dificuldade é que o próprio livro, ele é um fator limitante, ele só mostra aquela parte bem resumido, destacado do todo, quando você fala assim: tá aqui, isso é Geologia, isso é uma rocha sedimentar, ah tá? mas qual é a relação com tudo? Ah, Cavernas? Como é que seriam as cavernas? Então a grande dificuldade que eu vejo é de que ela é compartimentalizada, só as rochas naquilo, e o estudante não consegue ter uma visão de que a rocha depende pra formação do solo, que depende pra toda aquela parte do desenvolvimento dos seres vivos. Até mesmo nas eras que nós estudamos, nas eras geológicas, as mudanças que tem, né? Ah aqui a rocha sedimentar, olha que legal, mas tudo compactado. Sim, mas o que tinha antes das rochas? Como elas surgiram? A facilidade hoje eu vejo pela internet (risos) que hoje você tem um monte de imagens que você pode mostrar, que você resgatar, inclusive até livros universitários [...] Então o aluno ele já começa a abrir os horizontes. E outra, a facilidade que nesse caso pro sexto ano é que a Geologia é dada no mesmo período em que a Geografia está ensinando, então podemos fazer uma interdisciplinaridade, articular de que um pode, olha, você vai falar o que? Você vai falar sobre rochas? Então vou falar sobre a ecologia que está envolvida nessa rocha, como podemos ver a formação de uma praia? De onde vem as areiazinhas da praia? Como forma uma onda? Mas a formação da praia, a inclinação vai indicar os tipos de onda e os tipos de seres vivos que vivem naquela região, então isso começa a expandir” (BERILO).

A fala da professora Lazulita chamou muita atenção pelo fato desta mencionar a concepção do íntegro, alegando que não há a separação entre as partes do conhecimento, e sim que a unificação do todo é que proporciona o entendimento do saber. Essa concepção contrapõe o que é apontado por muitos docentes dentro do ensino de ciências, como explana Imbernon, et al., (2011, p. 91):

A divisão do conhecimento em áreas para um estudo aprofundado, imposta desde século XIX, influenciou o desenvolvimento das ciências, especialmente das Ciências 
Naturais (Terra, Universo, Vida, Física e Química). O que temos observado é que problemas complexos gerados pelo desenvolvimento das sociedades, difíceis de serem resolvidos por especialistas de forma isolada - como a questão do desenvolvimento auto-sustentável, por exemplo, carecem de uma visão sistêmica e interdisciplinar, que não se caracteriza na Educação Científica que se realiza nas escolas. Assim, em oposição ao modelo fragmentário de produção de conhecimentos e de ensino, emerge o paradigma da interdisciplinaridade, que deveria pautar a formação do professor de Ciências Naturais (IMBERNON et al., 2011, p. 91).

Já a fala de Berilo faz uma ressalva em relação ao livro didático, levantando uma questão que na maioria das vezes, não é alvo de preocupação de muitos educadores. Como o fato de o conteúdo científico estar disposto no recurso com conceitos tácitos e limitantes, não promovendo uma integração entre os fatos e fenômenos, o que não desencadeia a visão interdisciplinar que se espera no contexto do ensino de Geologia.

Conforme exposto por Fazenda (1998 p. 41), “o sentindo interdisciplinar precisa ser redimensionado quando se trata do saber teórico, sendo necessário romper as fronteiras entre as disciplinas, entre as mediações do saber, tanto na teoria, quanto na pesquisa". Essa concepção se reflete na fala do professor Berilo quando este enaltece que os temas de Geologia poderiam ser trabalhados juntamente com outras disciplinas, como é o caso da Geografia.

O ensino de Geologia permite articular temáticas que ultrapassam uma visão meramente disciplinar, o aluno é convidado a vislumbrar a interdisciplinaridade vista de diferentes pontos e que se encontram articuladas. Conforme Toledo (2005), a Geologia é uma ciência que permite integrar todos processos naturais do planeta (passado-presente) fornecendo desse modo, um sentido global aos fenômenos físicos e suas leis. Munidos desses conhecimentos é que professores e alunos poderão estabelecer uma compreensão da dinâmica do planeta, onde os fatos e fenômenos possam dar sentido aos acontecimentos terrestres, dentre eles as questões de ordem ambiental.

\subsubsection{Estratégias de ensino e recursos didáticos utilizados para trabalhar temas da}

\section{Geologia}

Em relação às estratégias de ensino e recursos didáticos adotados para trabalhar temas da Geologia, visando fazer uma aproximação com a realidade dos estudantes, os professores em sua maioria foram unânimes, utilizam recursos e estratégias variadas conforme apresentado a seguir (tabela 1): 
Tabela 1: Recursos e estratégias utilizadas no ensino de Geologia

\begin{tabular}{|c|c|c|}
\hline Professor & Recursos didáticos & Estratégias de ensino \\
\hline \multirow[t]{2}{*}{ BARITA } & Data show, livro didático & Aula expositiva \\
\hline & Experimentos & \\
\hline FLUORITA & $\begin{array}{l}\text { Livro didático, modelos, } \\
\text { simulação }\end{array}$ & Aulas investigativas e experimentais \\
\hline \multirow[t]{2}{*}{ APATITA } & $\begin{array}{l}\text { Livro didático, experimentos, } \\
\text { simulação }\end{array}$ & Aulas expositivas \\
\hline & & Aulas expositivas e "às vezes" saídas de \\
\hline AZURITA & Livro didático & campo \\
\hline \multicolumn{3}{|l|}{ BERILO } \\
\hline GALENA & Data show e livro didático & Modelagem e saídas de campo \\
\hline HALITA & $\begin{array}{c}\text { Textos e Reportagens de Jornais e } \\
\text { Revistas }\end{array}$ & $\begin{array}{c}\text { Modelagem, Atividades Lúdicas, Aulas } \\
\text { experimentais e abordagem CTS }\end{array}$ \\
\hline HEMATITA & Livro didático & Saídas de campo, aulas expositivas \\
\hline LAZULITA & $\begin{array}{l}\text { Imagens, material físico } \\
\text { (amostras de solo, rochas) }\end{array}$ & Aula investigativa e expositiva \\
\hline MALAQUITA & Data show, imagens & Aula expositiva \\
\hline PALÁDIO & Data show & Modelagem \\
\hline PIRITA & Data show & $\begin{array}{l}\text { Aulas experimentais, simulação e aulas } \\
\text { expositivas }\end{array}$ \\
\hline QUARTZO & Data show, livro didático & Aulas experimentais e saídas de campo \\
\hline SIDERITA & Data show & Simulação e aulas expositivas \\
\hline TURQUESA & Textos & Atividades experimentais \\
\hline
\end{tabular}

Observa-se que há uma utilização de recursos que vão além dos "tradicionais" (livro, quadro e giz). Somente uma professora citou a abordagem CTS como estratégia de ensino adotada nas aulas de ciências. Alguns docentes chegaram a destacar a sua realização em sala de aula, outros desconheciam a proposta, logo não chegaram a aplicá-la em nenhum momento nas aulas de Ciências Naturais.

É perceptível que há uma mínima adoção de práticas pedagógicas que fomentem o conhecimento científico com base na problematização da realidade social e ambiental vivenciada pelos estudantes. Conforme Zanotto e Rose (2003, p. 48), "a ação de problematizar acontece a partir da realidade que cerca o sujeito; a busca de explicação e solução visa a transformar aquela realidade, pela ação do próprio sujeito". Freire (1996) acrescenta ainda que a problematização permite a detecção de problemas na realidade visando a transformação do contexto que cerca os indivíduos. 
Ao serem questionados acerca dos recursos e estratégias que estes gostariam de vislumbrar em um curso de formação, os professores enfatizaram o uso da modelagem e de atividades que pudessem fomentar a ludicidade, a história das ciências e o contexto vivenciado pelos alunos.

\author{
"Acho que modelagem, e coisas da realidade dos alunos" (PALÁDIO). \\ "Modelagem, História das Ciências, talvez" (GALENA).
}

Os PCN reforçam essa ideia e ressaltam que:

É interessante a abordagem de aspectos da história das ciências e história das invenções tendo em perspectiva, por um lado, oferecer informações e condições de debate sobre relações entre ciência, tecnologia e sociedade e, por outro, chamar a atenção para características que constituem a natureza das ciências que os próprios alunos estão vivenciando em atividades de ensino (BRASIL, 19998, p. 60).

Dentro dessas sugestões, diversas atividades foram pesquisadas, adaptadas e reelaboradas conforme o interesse e a necessidade dos docentes, visando proporcionar o contato com estratégias de ensino passíveis de serem empregadas nas aulas de Ciências Naturais.

\title{
4.2 APLICAÇÃO DA PROPOSIÇÃO EDUCATIVA - CURSO "EDUCAÇÃO EM GEOLOGIA"
}

Após montado, o curso foi submetido ao Decanato de Extensão (DEX) da UnB, para aprovação da proposta, de modo que fosse possível viabilizar a certificação dos participantes e da equipe envolvida em sua realização.

A ação executada consistiu em encontros virtuais e presenciais que somados, possibilitaram a troca de conhecimentos rentes aos conceitos de Geologia e a reflexão perante a prática pedagógica realizada em sala, competência indispensável para a construção da identidade profissional e do fazer docente.

A estruturação do curso seguiu a seguinte organização:

a. Semana I (Encontro virtual) - (15/09) a (22/09): Foram abordados temas relacionados à Formação do Planeta Terra, Sistema Solar e Tempo Geológico, os participantes deveriam apresentar-se e interagir com os demais envolvidos, fomentando o processo de ambientação na plataforma. 
b. Semana II (Encontro virtual e presencial) - (23/09) a (28/09): O encontro virtual abordou temas inerentes aos Minerais, Rochas e Solos. O primeiro encontro presencial marcado para o dia 25/09 teve que ser cancelado por motivos de saúde da ministrante, sendo que os participantes não foram prejudicados em nenhum momento pela não ocorrência do mesmo, visto que as atividades preparadas para este momento foram aplicadas, discutidas e anexadas no encontro subsequente.

c. Semana III (Encontro virtual e presencial) - (29/09) a (06/10): Na terceira semana de curso, no ambiente virtual foi possível abordar o tema de Ciclo Hidrológico. Já no encontro presencial, estava previsto a abordagem do tema de Tectônica de Placas e Relevo. Para este encontro foram utilizados materiais de baixo custo que visaram enfatizar a estratégia metodológica da modelagem. Um dos materiais adotados foi o uso de "peças" em EVA de cores diversas, visando trabalhar com a construção de diferentes perfis tectônicos, dessa forma, cada cor indicou um elemento distinto dentro de cada perfil a ser montado, como por exemplo, a convergência de placas oceânicas (Figura 1).

Como já discutido ao longo da bibliografia apresentada, os temas apresentam ampla conexão uns com os outros, o que favoreceu a abordagem da história evolutiva do planeta Terra, sendo assim, no segundo encontro presencial, realizado no dia 09/10, foi realizada também uma discussão acerca dos conceitos de Mineral, Rocha, Solos. Foram selecionados materiais naturais para a explanação desses conceitos, tais como amostras de solos de diferentes perfis que compõem o território do DF, bem como diversas amostras de rochas sedimentares e metamórficas encontradas no mesmo (figura 2). Rochas ígneas, por não existirem no DF, foram exemplificadas por amostras de outras regiões do Brasil. As relações desencadeadas com as questões chaves trabalhadas no espaço virtual nas semanas anteriores, também foram abordadas, tais como: as teorias que buscam explicar a Origem da Vida, do Sistema Solar, a importância do Saber Científico e do Saber Comum, bem como dos artigos científicos sugeridos como leitura complementar. 


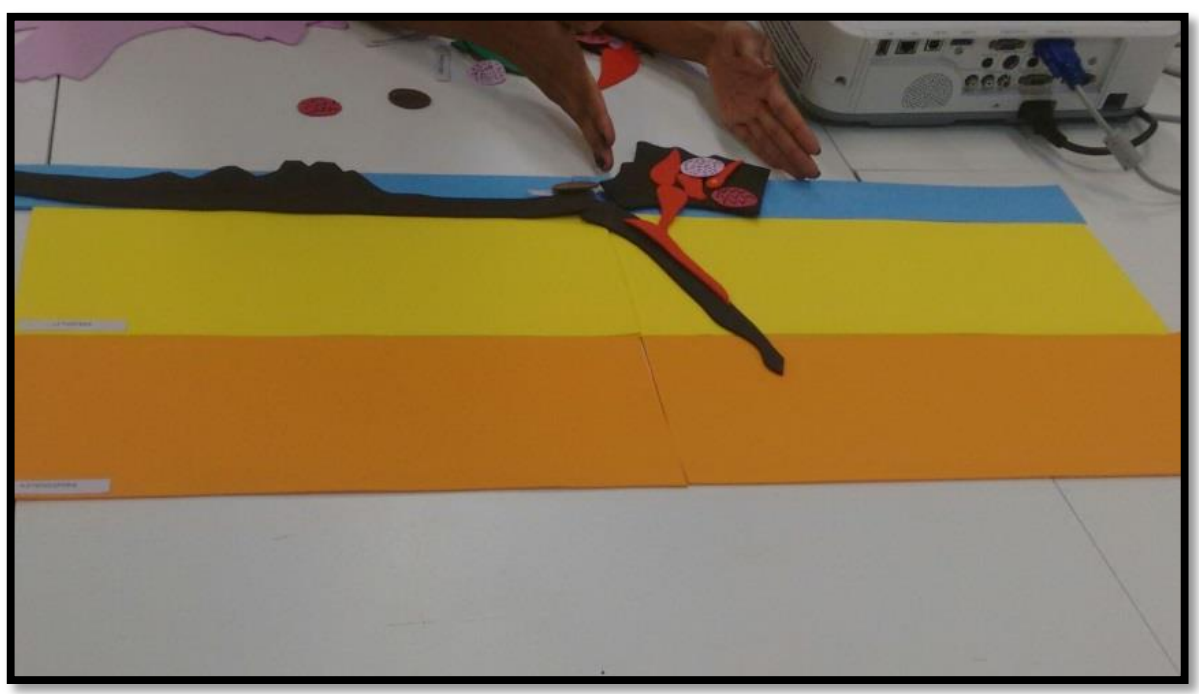

Figura 1. Modelando o Perfil Tectônico Terrestre Foto: Gaby Camargo (2015)

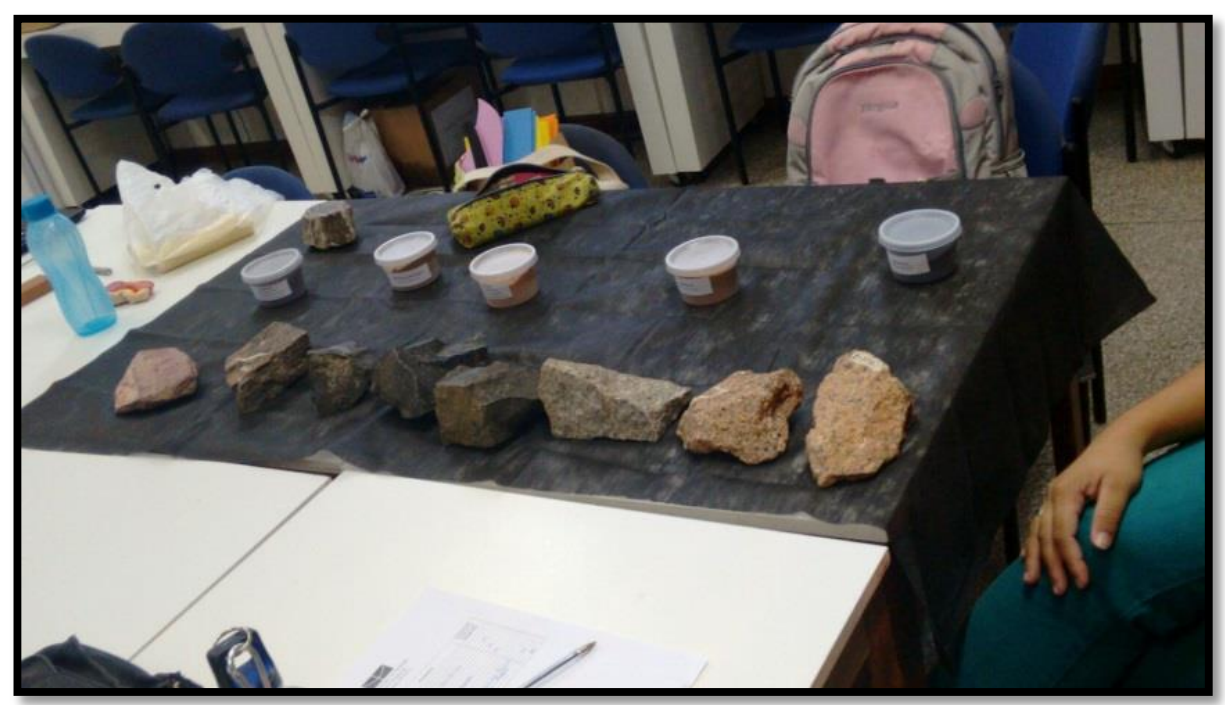

Figura 2. Amostras de solos e rochas Foto: Gaby Camargo (2015)

d. Semana IV (Encontro virtual e presencial) - (07/10) a (15/10): Na última semana de curso foi solicitado no ambiente virtual que os participantes elaborassem uma proposta de visita a um espaço não formal de ensino, explorando todos os temas vistos e discutidos ao longo do curso de formação continuada. No encontro presencial, ocorrido no dia 15/10 (figura 3) foi realizada uma visita ao Museu de Geociências da UnB, bem como discutido com os participantes a importância desses espaços para o processo formativo dos estudantes. A visita foi guiada pelos estagiários do Museu e ocorreu nos dois turnos, das 9h às $11 \mathrm{~h}$ da manhã e das $14 \mathrm{~h}$ às $16 \mathrm{~h}$ da tarde. Os participantes deveriam escolher o turno da visita, de acordo com seus horários e cronograma escolar. A visita (figura 4) propiciou aos participantes o contato com 
os principais conceitos trabalhados ao longo do curso, além de fomentar o contato destes com os exemplares e amostras geológicas disponibilizadas no museu.

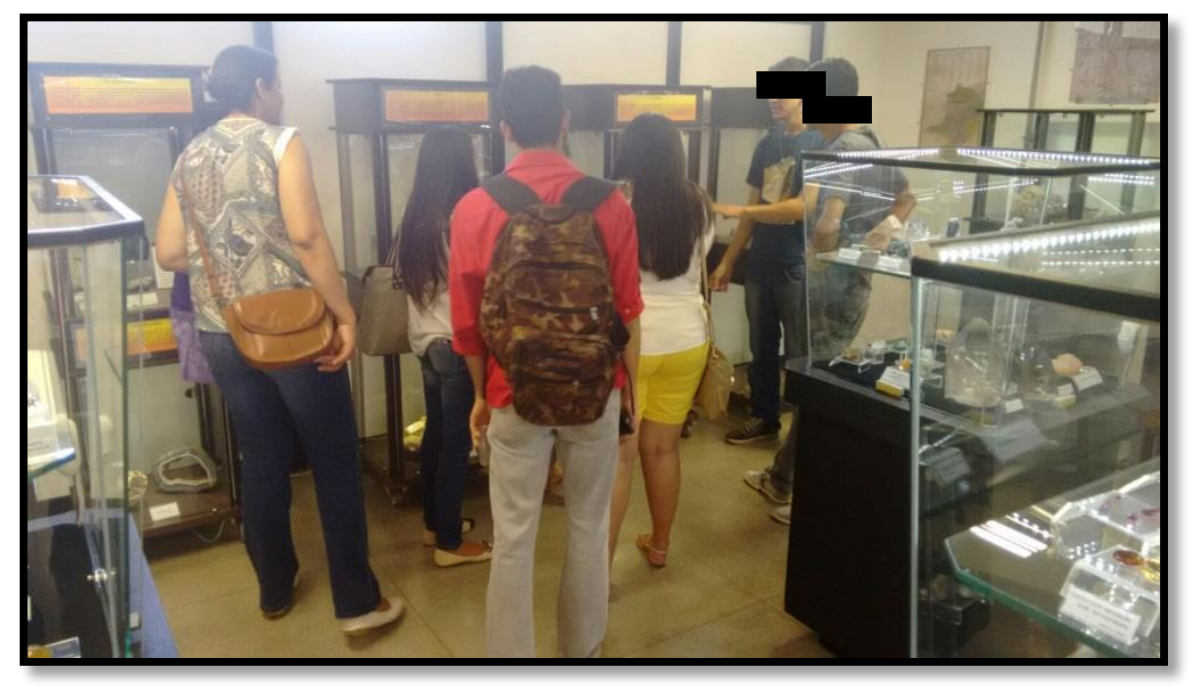

Figura 3. Visita ao Museu de Geociências da UnB Foto: Edelvan Correia (2015)

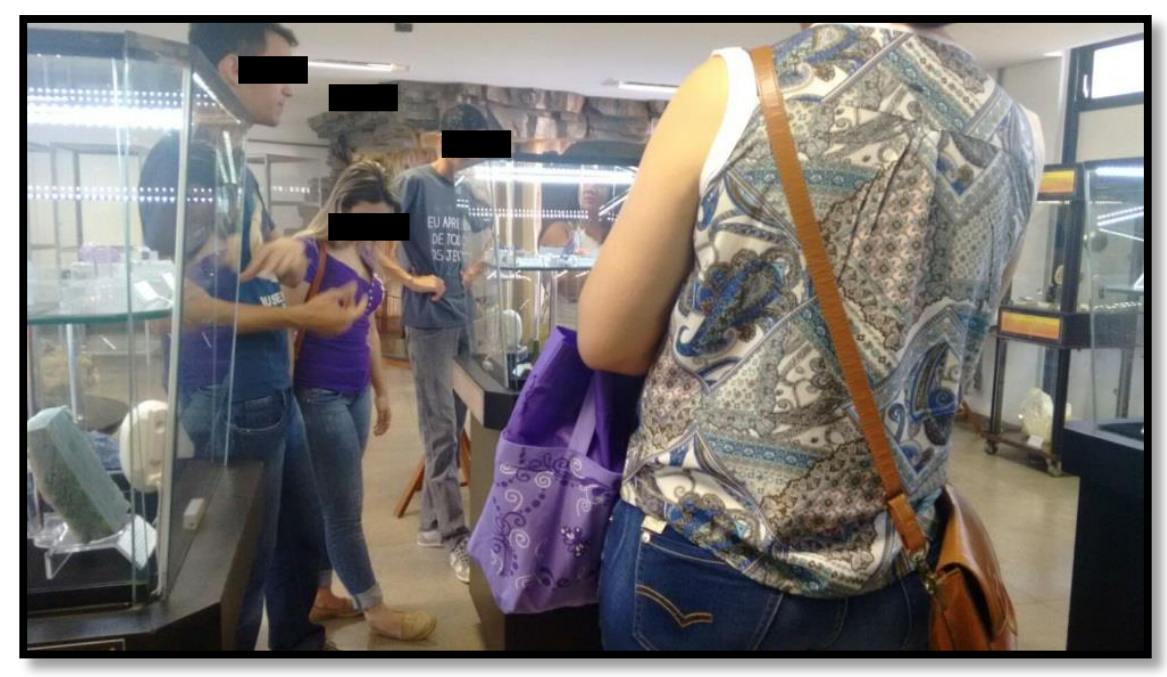

Figura 4. Visita ao Museu de Geociências da UnB Foto: Samara dos Anjos (2015)

Sendo assim, com a execução da proposta, foi possível discutir questões e conceitos pertinentes ao campo de estudo da Geologia e do ensino de Ciências, o que possivelmente agregou saberes, práticas e estratégias metodológicas passíveis de serem empregadas em sala, durante as aulas de Ciências Naturais. 


\subsection{PERCEPÇÕES ACERCA DA PROPOSIÇÃO DESENVOLVIDA}

Este terceiro tópico do estudo refere-se às percepções coletadas acerca da aplicação da proposição de intervenção educativa. Assim, como para a etapa inicial, na etapa avaliativa também foi adotado o uso de entrevistas semiestruturadas para coleta dos dados. Posteriormente, foi realizada uma análise qualitativa das respostas apresentada pelos participantes da pesquisa. Para esta etapa, dos quinze participantes, nove concluíram o curso ofertado, sendo eles: Apatita, Berilo, Quartzo, Fluorita, Galena, Halita, Pirita, Siderita e Turquesa. Os demais desistiram por motivos pessoais e profissionais, tais como de saúde e sobrecarga de atividades escolares.

Tomando como base a metodologia exposta, os resultados obtidos com esta etapa de pesquisa encontram-se elencados de acordo com as seguintes categorias: 1) contributos da formação continuada para a prática docente; 2) um olhar acerca das atividades desenvolvidas - Geologia em destaque; 3) a educação a distância como uma modalidade de formação continuada; 4) contribuições do curso para o professor de Ciências Naturais e 5) avaliação da proposição educativa.

\subsubsection{Contributos da formação continuada para a prática docente}

A prática docente desencadeada em sala é responsável pela postura do professor frente à superação de conflitos, a seleção de metodologias de ensino, aos impasses conceituais tanto oriundos de sua formação inicial, como daqueles que emergem no decorrer do processo de ensino e aprendizagem dos alunos. Ao experienciar o cotidiano escolar em todas as suas esferas, o professor observa que, ele é um profissional em constante transformação e, que nem sempre é possível superar os obstáculos como se deseja.

Diante dessas questões é que o professor percebe o quanto a formação continuada pode contribuir para a minimização de problemáticas que por vezes emergem em seu contexto, dificultando sua ânsia em desenvolver uma prática mais promissora. Logo, ao serem indagados sobre a importância dos cursos de formação continuada para o constructo profissional do docente, os professores foram unânimes em suas respostas e afirmaram que: 
“Eu acho que é importantíssimo, porque é uma forma da gente tá reciclando. É isso que eu te falei, quando eu fiz a faculdade eu tive um modelo de preparação, eu vi toda a parte teórica e eu cheguei na sala de aula sem experiência nenhuma, e eu acho que a maioria dos professores que entraram comigo, né? Eles tiveram essa didática, tiveram aula, e pronto, foram pra sala, sem preparação nenhuma. E a gente precisa fazer curso de formação pra poder abrir os horizontes, porque senão a gente fica sempre trabalhando daquela mesma forma e você não muda, né? E hoje eu acho que a educação requer uma metodologia diversificada, diferente, o nosso aluno cobra uma postura diferente do professor, o aluno de hoje não é o aluno como eu era né? Que o professor tava lá e a gente cá, não tinha relacionamento, não tinha vínculo nenhum, o professor falava e a gente acatava aquilo como o certo, hoje o aluno questiona, pergunta [...] Então eu acho que a gente precisa melhorar, o curso de formação ajuda muito nessa questão" (PIRITA).

"Não, então, a educação ela não é estagnada, então sempre vão ter novas teorias, sempre tem várias coisas, e pra gente ter acesso, a gente tem que ter uma formação continuada, se você pegar um professor que se formou há 20 anos atrás e um que se formou hoje, vai ter muita diferença nesse tempo, então o professor, ele tem que tá sempre se atualizando pra que os alunos também tenham essa atualização, se não fica uma coisa parada, então como as coisas evoluem, o professor também tem que evoluir, a gente não vai fazer faculdade a vida inteira, tem que fazer a formação continuada" (SIDERITA).

É perceptível na fala de Pirita que a formação continuada permite que o professor aperfeiçoe a sua didática, esta que é implantada nos cursos de licenciatura, nos quais os alunos, futuros docentes passam por estágios de preparação profissional, tendo como objetivo adquirir e desenvolver determinadas habilidades, capacidades e atitudes que possam desencadear uma postura profícua dentro da área específica de ensino escolhida (ALARCÃO, 2006). Pirita enseja que uma articulação entre a didática e o fazer docente em sala de aula, permite que o professor possa se envolver, refletir acerca dos atos que envolvem o processo de ensino, visando uma transformação que esteja mais equiparada com a realidade dos seus educandos.

O conhecimento acerca de uma nova didática também pode ser observado na fala de Siderita, quando esta aponta que a diferença estabelecida nos processos de formação dentro de uma escala temporal, denota uma modificação profunda no modo como cada profissional atua em sala e desenvolve sua didática pedagógica. Neste sentido, o processo mediático, base da didática escolar, implica no desenvolvimento de dois fatores indispensáveis no ato de continuidade de formação do professor, sendo elas o desenvolvimento de capacidades, tais 
como comunicação, decisão, monitoração, reflexão e atitudes frente a disciplina, ao ensino e a inovação (ALARCÃO, 2006). Deve ser levado em consideração ainda, os objetivos relacionados com a disciplina, ilustrando a importância dos conhecimentos desta para os alunos, destacando quais concepções de ensino devem ser retomadas e quais devem ser descartadas para dar lugar a novas ações que promovam a ressignificação do ensino.

Logo, se o professor que atua em sala já não é mesmo de décadas passadas, o sujeito do conhecimento, ou seja, o aluno também já não é o mesmo, fator este levantado na fala de Pirita e Siderita. Sendo a aprendizagem fruto de ações desencadeadas pelo sujeito, em meios diversos, tais como políticos, sociais e culturais, cada momento será marcado pela evolução e pelo modo como estes meios interferem nos mais diversos momentos ao longo da vivência de cada ser. Sendo assim, quando nos reportamos aos espaços que envolvem diretamente a escola, devemos estar atentos ao desempenho do professor, considerando os efeitos que a adoção de determinadas atitudes podem desencadear na forma de ensinar e consequentemente na forma de aprender do nosso atual público de estudantes (DELIZOICOV; ANGOTTI; PERNAMBUCO, 2011).

Outro ponto destacado pelos sujeitos de pesquisa e que na visão destes é indispensável, está centrado no que os cursos de formação continuada, de uma forma geral, podem agregar tanto em termos práticos como teóricos, fator este enfatizado por Apatita em sua fala:

\footnotetext{
"Eu acho de fundamental importância, porque o professor tem que estar sempre atualizado, ele tem que tá atento às novas tendências, as novas tecnologias, novos assuntos que estão dentro do cotidiano dos alunos, e esses cursos de formação eles podem propiciar todo esse conhecimento pro professor levar pra sala de aula, pra ele não ficar bitolado e preso a uma única metodologia, a poucos métodos" (APATITA).
}

Apatita aposta que os cursos de formação continuada possuem dentre outros objetivos, o de atualizar os aspectos formativos da profissão docente. Entretanto, como apontado por Pimenta (1997, p. 6), não basta somente atualizar, os cursos de formação continuada devem permitir que o "professor transforme sua identidade enquanto profissional, adquirindo uma habilitação legal ao exercício profissional da docência, do curso de formação inicial se espera que forme o professor, ou que colabore para sua formação". Para Nóvoa (1995, p. 12), essa ressignificação permite que o professor "desempenhe um papel importante na adoção de uma nova personalidade docente, estimulando uma cultura profissional e emergencial dentro das escolas". 
Ainda seguindo a premissa da importância que a formação continuada desencadeia na realidade dos professores, foram questionados aos mesmos, quais impactos que os cursos de formação continuada exercem, se tratando da prática cotidiana de sala de aula:

“[...] Positivamente o curso agrega mais conhecimento, porque, por exemplo, é, algumas coisas do próprio curso, que eu havia visto na faculdade, vamos colocar aí mais de dezesseis anos, agregou demais, porque eram coisas esquecidas, algumas coisas eu comecei a aprender né? Alguns videozinhos que você colocou que foram muito interessantes, que aí já coloquei nos meus planejamentos de aula pra não esquecer porque enriquece muito, né? Pra prática pedagógica acho que é realmente isso, é a gente agregar cada vez mais o saber, né?!” (QUARTZO).

"O professor ele muda a postura quando ele quer, porque ele aprende novas formas de aplicar determinado recurso ou ele muda mesmo a metodologia, a forma dele se portar em sala de aula, quando ele vê as tendências pedagógicas” (HALITA).

"Eu acho que se o professor ele aproveita, né, realmente, se ele entende o intuito, eu acho que tem um impacto principalmente na forma de ensinar, porque da mesma forma que eu recebi aquele conhecimento, eu tenho que saber né, como ensinar esse conhecimento para o esse meu aluno, então acho que o principal impacto é na docência mesmo, na forma de ensinar" (GALENA).

Pelas falas apresentadas por Quartzo, Halita e Galena, podemos identificar três premissas consideradas impactantes ao docente, quando este se integra ao processo de continuidade de sua formação, sendo elas: a) agregação de conhecimento; b) mudança de postura e c) saber ensinar.

Conforme TARDIF (2000, p. 10), a profissionalização visa "renovar os fundamentos epistemológicos do ofício de professor”. Sendo assim, o fato de o professor buscar agregar o conhecimento está presente neste cerne, uma vez que na prática cotidiana do docente este necessita relacionar os conhecimentos científicos aos sociais, integrando-os àqueles adquiridos em sua formação e, modelando-os para serem postos em prática de acordo com a realidade escolar que este possa vir a se deparar. Logo, agregar o conhecimento em um curso de formação continuada não significa trabalhar somente com a práxis teórica, mas sim, mergulhar em um contexto que privilegie a autogestão do saber (TARDIF; GAUTHIER, 1999).

A mudança de postura citada por Halita enseja que o professor seja capaz de se autoformar e gerenciar o método pedagógico do qual este é adepto. Fomentar novos mecanismos de trabalho e novas bases teóricas no ensino, implica que este profissional revise, 
critique e partilhe sua prática, sendo capaz de assumir novas posturas diante de novos públicos e concomitante, novas realidades. Conforme é discutido por Freire (1996, p. 14), o exercício da docência implica em ir além da mudança como também:

[...] assumir riscos, aceitar o novo, rejeitar qualquer forma de discriminação, reflexão crítica sobre a prática, reconhecimento e assunção da identidade cultural, ter consciência do inacabamento, reconhecer-se como um ser condicionado, respeitar a autonomia do ser educando, bom senso, humildade, tolerância, convicção de que mudar é possível, curiosidade, competência profissional (FREIRE, 1996, p. 14).

Sobre a potencialidade mencionada por Galena, o professor deve saber ensinar e saber o que se está ensinando, essa é a didática que deve estar presente no processo que alude ensinar e aprender. De acordo com FREIRE (1996, p. 15), mediante a essa reformulação do saber, "percebe-se, assim, a importância do papel do educador, o mérito da paz com que viva a certeza de que faz parte de sua tarefa docente não apenas ensinar os conteúdos, mas também ensinar a pensar certo".

Saber ensinar exige mais que saber os conhecimentos específicos, mais do que se ter uma experiência, exige saberes que implicam em uma didática capaz de ser reformulada pelo professor (PIMENTA, 1997). Para Elliot (1993), mediante a avaliação, reformulação e da compreensão acerca daquilo que deve ser mudado, o saber se transforma, a mudança precede a compreensão.

Quando questionados a respeito do papel exercido pelos cursos de formação continuada em relação à agregação dos conhecimentos e a sua associação àqueles saberes adquiridos em outros momentos de formação, os professores em sua maioria enfatizaram que a construção é pertinente e, que as frentes de aprendizagem desencadeadas ao longo da formação ainda na base universitária e das experiências provenientes do ato da profissão os permite esclarecer e ter ciência daquilo que pode ser melhorado e eventualmente adotado no ensino.

"Ele vai instrumentalizar o professor sim, quando eu comecei a dar aula, eu não tinha quase nada, era só livro. Se eu não abro novas perspectivas, novos horizontes, não busco fazer os cursos, o que eu vou aprender, melhor o que eu vou ensinar ao estudante além daquilo que tá no livro? Então o curso de formação ele dá essa oportunidade de abrir, expandir, vamos procurar mais cursos” (BERILO).

"Eu acredito que sim, é uma forma de você melhorar o que você aprendeu, né, porque a priori é lógico que tem algumas novidades, mas o que eu aprendi, você aprendeu, é lógico que você viu uma parte mais abrangente, porque a, o conhecimento vai aumentando né? As informações elas vão aumentado, então quando eu aprendi Universo, eu aprendi Universo de uma forma mais limitada, a 
visão que hoje a gente tem de Universo é diferente de quando eu estudava, que o professor tinha e me passou, então eu acho que o que aprendi, ele é... tudo que eu aprendi agora no curso de formação ele foi o que adicionado ao que eu já tinha como base, né, você não vai apagar o que eu tinha, não vou apagar e vou trabalhar só o que eu tenho agora, não, ele vem e foi melhorado" (PIRITA).

Em relação a mesma indagação, a participante Galena levantou alguns pontos plausíveis de serem discutidos nesta investigação, se opondo a fala dos participantes anteriores:

\footnotetext{
"Alguns sim, alguns cursos eu acho que sim, que agrega, né, que faz essa junção, mas alguns, outros cursos eu acho que não estão muito interligados assim, acho que é muito separado, às vezes é muito só pra crescimento funcional mesmo, do funcionário, e não agrega muita coisa às vezes o curso, acho que os curso hoje em dia eles estão muito voltados é, muito superficial e ou quando não é superficial ele tá muito voltado pro conteúdo e não pra prática do professor, que eu acho que além do conteúdo, acho que mais importante pro professor é a prática, porque o conteúdo você pode estudar e aprender, mas a prática não" (GALENA).
}

O primeiro deles é a progressão do profissional, Galena enseja que muitos cursos só são ofertados com o intuito de fazer essa "promoção", esta que está mais ligada ao cunho financeiro do que a melhoria do ensino em si. Entretanto, não só os cursos que são disponibilizados aos professores que trazem à tona esta questão, a decisão em participar de um curso de formação continuada deve partir da ânsia que o docente tem em querer mudar aquela realidade da qual ele faz parte, promovendo a auto capacidade de se transformar em um instrumento qualitativo, com vistas ao aperfeiçoamento de concepções educacionais. Como exposto por Nóvoa (1995, p. 19), “o que está atualmente em causa não é apenas o aperfeiçoamento, a qualificação ou a progressão na carreira docente; a vários títulos, joga-se também aqui a possibilidade de uma reforma educativa coerente e inovadora".

O segundo ponto na fala reflete a falta de propostas embasadas na interdisciplinaridade, que de fato abarque uma concepção de ensino capaz de interligar os saberes e/ou mais do que isso, fundamentá-los com base nas concepções de uma ciência única, tornando possível a compreensão do todo. Entretanto Justina (2002), enfatiza que a troca com outros saberes exige cautela e em alguns casos espera, é necessário realizar uma leitura disciplinar, para que seja possível compreender a possibilidade das múltiplas leituras, mediante a isso, a interdisciplinaridade permitirá olhar o que não se mostra, além de desencadear um raciocínio para aquilo que não se consegue distinguir. 
O terceiro e último ponto mencionado está relacionado ao direcionamento atual dos cursos de formação continuada. Na concepção de Galena estes têm deixado a desejar quando se trata da prática do professor, uma vez que estão privilegiando os conceitos relativos ao conteúdo e não ao processo de ensino em si. Nóvoa (1995), em relação a esta questão acredita que:

\footnotetext{
Não há ainda uma tradição que condicione as práticas e os modelos a implantar. É preciso fazer um esforço de troca e de partilha de experiências de formação, realizadas pelas escolas e pelas instituições de ensino superior, criando progressivamente uma nova cultura da formação de professores (NÓVOA, 1995, p. 19).
}

Torna-se necessário, na elaboração de um curso de formação continuada, propiciar espaços para que os futuros participantes possam expor suas questões profissionais, que via de regra, costumam se apresentar como problemáticas emergentes, oriundas nas mais variadas realidades escolares. Dependendo do público e do ambiente, cada curso poderá desencadear um resultado diferente, fornecido para alcançar um objetivo distinto.

Conforme Freire (1991, p. 10), "a gente se faz educador, a gente se forma, como educador, permanentemente, na prática e na reflexão sobre a prática" o que se soma às concepções expostas por Pimenta (1997, p. 10), de que os cursos de formação continuada não consistem em privilegiar um fator ou outro, mas sim "em superar a tradicional fragmentação dos saberes da docência, tais como os saberes científicos, saberes da experiência e saberes pedagógicos", apontados por Freire (1996) e Tardif (2000).

\subsubsection{Um olhar acerca das atividades desenvolvidas - Geologia em destaque}

Foram desenvolvidas uma série de atividades ao longo do curso de formação continuada, estas buscaram focar não só nos conteúdos de Geologia, como também nas diversas estratégias de ensino que poderiam ser exploradas e adotadas de acordo com determinado tema.

Para tanto, na presente investigação não foi realizada uma análise das atividades em individual, visto que a proposta esteve centrada na construção do curso em conjunto com os participantes, na elaboração de atividades com o intuito de mediar os conceitos geológicos, bem como executá-las seguindo as estratégias metodológicas mais pertinentes do ensino de 
ciências. Sendo assim, a proposta foi avaliada considerando-se os aspectos fundamentais de um curso de formação, tais como pessoal, profissional e organizacional (NÓVOA, 1995).

Foi questionado aos participantes se a proposta executada atendeu às expectativas deles em relação à formação docente e aos assuntos mais pertinentes da Geologia. Os participantes expuseram suas percepções:

"Sim, até passou, fomos até além, porque eu tava pensando que ia ser só na Geologia, aí quando começamos a ver o Universo, o Sistema Solar, mostrando até aquele programinha, o software, nossa, abrangeu muito mais do que eu imaginei, por que? Porque é isso que eu falei, normalmente sempre pensamos quando se fala em Geologia só aqui, não, mas calma aí, vem lá do Universo pra cá, como é que isso daqui foi formado? Vem de lá, então vamos expandir nosso conhecimento, então é por isso que o curso de formação é interessante porque ele começar a mostrar novos horizontes, novos caminhos" (BERILO).

Pela fala de Berilo é possível salientar que a perspectiva interdisciplinar pôde ser trabalhada ao longo do curso, isso porque a Geologia como uma ciência história e interpretativa utiliza-se de fatos oriundos de diversas áreas do conhecimento para decifrar determinadas evidências, registros do passado planetário e problemas emergentes do cenário natural atual. Conforme enseja Frodeman (2010, p. 97), "a Geologia é um exemplo proeminente de ciência sintética, combinando uma série de técnicas lógicas na solução de seus problemas".

\footnotetext{
"Ah, muito, nossa! Igual eu te falei, eu vi Geologia assim em uma semana muito básico com o professor, né, por causa do curso, então assim, eu nunca tinha visto, nunca tinha estudado Geologia, assim no livro de ciências vem, fala alguma coisa sobre, mas e você trabalha, quando você vai preparar uma aula, você lê aqueles textos procura alguma coisa pra trabalhar, mas eu nunca tive aula de Geologia, então eu vim ter um pouco de noção, no curso de formação da UnB, e aí quando você começou ai foi bom porque os meninos do PIBID estavam trabalhando o mesmo conteúdo e aí como eles estavam trabalhando, todas as informações que eles iam passando eu ia prestando atenção [...] Porque eu sou uma pessoa assim, se eu não sei eu admito que eu não sei, não é porque eu sou a professora que eu sou a detentora do saber [...] aí seu curso chegou bem depois e aí me ajudou bastante também, algumas coisas eu já tinha noção e outras não" (PIRITA).
}

Já a fala de Pirita reflete o pouco contato estabelecido com a Geologia durante os momentos de sua formação, mais uma vez é perceptível o quanto a prática pedagógica pode ilustrar quais as dificuldades os docentes costumam enfrentar em sala de aula e, quais 
mecanismos os mesmos podem adotar para minimizar os impasses mais alarmantes dentro da perspectiva de ensino. Deste modo, as práticas servem como uma via de contribuição que privilegia a conexão entre o que saber e o que fazer diante dos entraves nas aulas de ciências (CARVALHO; GIL-PÉREZ, 2011).

Apatita e Halita ilustram nos comentários apresentados abaixo que foi possível desenvolver uma didática proeminente frente aos conteúdos de Geologia e ao contexto do qual esta deverá ser trabalhada:

\footnotetext{
"Sim, até porque como eu mencionei antes, os conceitos de Geologia, a Geologia em si é uma área que eu tenho uma certa dificuldade de trabalhar, então participando desse curso eu pude ver novos horizontes da Geologia, como se trabalhar, como levar o conceito pros alunos pra que fique mais fácil pra eles entenderem, pra não ficar abstrato, então agregou bastante" (APATITA).

"Com certeza, porque o curso ele fez o panorama de alguns temas e trabalhando isso de como a gente poderia trabalhar isso em sala de aula, então ele fez a gente pensar nos conceitos inerentes aqueles conteúdos e ele também fez a gente pensar em como a gente poderia abordar tais conteúdos na prática" (HALITA).
}

Isso demonstra que o objetivo do curso de formação em atrelar os conhecimentos mais pertinentes da Geologia focando-se em estratégias didáticas passíveis de serem utilizadas em sala de aula foi atendido. Conforme ilustrado por Alvarez-Suárez (2003), as representações dos fenômenos geológicos requerem a utilização de estratégias de ensino que permitam uma reprodução dos fenômenos de acordo com o que ocorre de fato na realidade do planeta Terra. Questão essa que levanta a importância do desenvolvimento de metodologias que possam alavancar o conhecimento dos docentes acerca do planeta Terra (GONÇALVES; SICCA, 2005).

Outra indagação realizada acerca das atividades focou nos conteúdos ministrados e trabalhados ao longo do curso, quando questionados se estes temas atenderam às suas perspectivas profissionais, os participantes em sua maioria expuseram as seguintes concepções:

"Sim, por exemplo, era geológica em um ano. Eu achei legal aquele cálculo. Foi por
quê? Porque normalmente você já pega pronto, ai quando você começa a fazer o
cálculo, a construir aí você vai percebendo o distanciamento, às vezes, de um
período para o outro, de uma, por exemplo, formação, fim dos dinossauros, inicio
dos hominídeos, que eles sempre perguntam, né? Os hominídeos entraram em 
contato com os dinossauros, porque os filmes sempre mostram isso, né? Ó um morreu aqui, o outro tá mais pra lá” (BERILO).

Berilo cita uma das atividades realizadas durante a execução do curso, cujo tema foi Tempo Geológico. O docente aponta a importância da interpretação dos fatos científicos dentro da Geologia, da investigação no processo de ensino e de sua implantação em sala de aula. Testemunha como é possível, por intermédio de uma mediação pedagógica comparativa, ter noções iniciais de "Tempo Profundo", ou tempo em bilhões de anos, uma das maiores dificuldades de aprendizagem apontada no ensino de Geologia. Potapova (1968) já ilustrava a importância de estudar os fenômenos geológicos durante seu desenvolvimento, uma vez que essa prospecção permite compreender que o processo evolutivo do planeta Terra é fruto de uma ciência que possui por natureza, uma característica histórico-geológica de um longo período de tempo.

A abordagem da Geologia em sala permite que o docente explore esse campo da investigação e interpretação, as atividades e intervenções do professor podem promover a reflexão, solicitando que os estudantes sejam capazes de lançar argumentos e evidências, frente às informações intrínsecas a história da ciência (DRIVER, et al., 1999).

O comentário de Pirita, Galena e Turquesa evidencia uma abordagem realizada de acordo com o contexto e a realidade vivenciada por professores e alunos:

\footnotetext{
"Com certeza, ficou mais fácil, nossa, assim, abriu minha visão, os meninos tinham trabalhado e assim a minha visão ficou mais, eu entendo agora o que é uma rocha, um mineral, ficou mais claro, eu aprendi muito e gostei." (PIRITA)

"Sim, perfeitamente. Todos os conteúdos acho que atenderam as expectativas, eu acho que foram bem abordados os conteúdos, eu acho que estavam bem completos né, então assim, não faltou nada em relação ao conteúdo" (GALENA).

"Sim, sim, os cursos que foram, os temas abordados durante o curso é exatamente o que a gente vivencia né, que tem que ser trabalhado em sala de aula, no Ensino Fundamental, justamente na nossa área onde atuamos, então foi bastante positivo nesse ponto, com certeza atingiu sim, foram os conteúdos que são trabalhados" (TURQUESA).
}

Freire (1987) questionou o trabalho escolar e sua mediação com base na realidade em que os estudantes encontram-se inseridos, segundo ele, o ensino deveria ser estabelecido pelo desenvolvimento de um elo que privilegiasse os saberes curriculares associados à experiência social desencadeada pelos indivíduos. Essa premissa é um fator importante se tratando do 
ensino, a busca por questões próximas aos estudantes pode promover uma conexão aos temas de ciências, de CTS e no caso desta investigação, aos temas de Geologia.

\subsubsection{Contribuições do curso "Educação em Geologia" para o professor de Ciências Naturais}

Esta categoria refere-se às contribuições que o curso proporcionou aos participantes, aos aspectos que se relacionam com uma abordagem da Geologia adotando-se uma concepção interdisciplinar, ambiental e integrada em sala de aula, bem como se as atividades foram trabalhadas satisfatoriamente.

Ao se tratar da interdisciplinaridade e das questões ambientais - duas prospecções que estão diretamente ligadas à Geologia - os participantes forneceram os seguintes comentários acerca da proposta desenvolvida:

\footnotetext{
"Sim, porque você nos mostrou durante o curso, principalmente na aula presencial, eu pude perceber, capitar mais essa essência, de que a Geologia enfim tá envolvida com inúmeras, é um tema interdisciplinar com certeza, envolve inúmeras questões ambientais, etc. Com certeza faz parte desse, da Ciência, né. Do campo de Ciências Naturais e foi enriquecedor trabalhar com essa proposta" (TURQUESA).

"Ambiental e Interdisciplinar? Algumas atividades talvez ajudasse, alguns conteúdos que estavam lá fossem bem voltados e ajude o professor, né, ajude a gente a ter uma prática interdisciplinar e voltado para o meio ambiente como aquela lá da água e essas questões, acho que sim, mas não são todos, acho que ajuda bastante, da pro professor uma visão interdisciplinar, porque a Geologia ela é interdisciplinar né, então, qualquer conteúdo que você ver na Geologia, se você for, né, voltar pra interdisciplinaridade é bem tranquilo, né, então eu acho que ajuda bastante sim" (GALENA).
}

Turquesa evidencia que ao participar do curso pôde perceber o quanto a Geologia está diretamente correlacionada com outras áreas do saber, como também com temas da ordem ambiental. Essa visão é indispensável para o professor de Ciências Naturais, pois este deve exercer uma postura reflexiva, promover a construção de uma cultura voltada para a sustentabilidade nos estudantes, no qual seja enfatizada a importância de buscar estabelecer 
uma convivência harmônica entres os seres vivos e a natureza mediante ao tratamento das questões ambientais de forma interdisciplinar (GADOTTI, 2009; TOLEDO, 2005).

O entendimento da importância em preservar o planeta das problemáticas ambientais é um dos princípios básicos lançados no "Tratado de Educação ambiental para sociedades sustentáveis e responsabilidade global" realizado em 1992, o documento enseja que a educação ambiental deve focar na relação entre o ser humano, a natureza e o Universo de forma interdisciplinar, auxiliando os cidadãos a desenvolver uma sensibilidade perante as formas de vida que compartilhamos espaço no planeta, respeitando seus ciclos vitais e impondo limite às ameaças que possam interferir na ordem global planetária (FÓRUM GLOBAL 92, 1992).

A fala de Galena ilustra a visão interdisciplinar dentro da Geologia, apontando a área como uma ciência facilitadora deste processo. Entretanto, para que o professor esteja apto a exercitar a interdisciplinaridade, não basta conhecer apenas a sua teoria, a interdisciplinaridade é ajustada na prática, é testada na vivência estabelecida dentro de sala, em conjunto com outras áreas do saber e, em parceria com profissionais que estejam dispostos a promover a construção dessa visão no campo conceitual e prático do aluno. Compiani (2005) reforça essa dificuldade e explicita que a estrutura pedagógica encontrada atualmente nas escolas, não permite que o professor possa avançar na prática pedagógica com base num ensino de Geologia mais interdisciplinar.

A parceria, um dos termos chaves posto em evidência na visão interdisciplinar apresentada por Fazenda (1998), enseja que esta só se estabelece com os sujeitos e com os conhecimentos sociais, históricos e culturais, estes colocados em prática, podem fazer a interdisciplinaridade ser exercida, revelando aspectos promissores no ato de ensinar e aprender, dos quais só podem se processar mediante a reflexão da prática cotidiana.

As falas de Apatita e Fluorita salientam a realização de algumas atividades do curso adotando-se a abordagem CTS:

"Sim, algumas atividades elas tiveram essa vertente né, como as de CTS, que é você levar o conteúdo de forma que o aluno possa refletir e observar dentro do seu cotidiano e dentro do ambiente em que ele está inserido. Então vários temas que foram abordados no curso, eles ofereceram essa questão pra gente” (APATITA).

"Sim, com certeza. Então, acho que teve um momento em uma atividade que você pediu pra atrelar um conceito da Geologia com um conceito local que a gente estava inserido, então eu acho que nesses determinados momentos, é... foi questionado essa perspectiva" (FLUORITA). 
A proposta de se trabalhar algumas atividades no curso, trazendo a perspectiva do ensino com base na abordagem CTS, busca instigar os docentes a conhecer esse tipo de estratégia, bem como torná-los conhecedores das causas, efeitos e concepções que estão relacionadas ao desenvolver tal abordagem no ambiente escolar. Isso porque, para que ocorra a implantação de propostas que estejam relacionadas com o mundo escolar e o contexto atual, o ensino de ciências requer um professor que seja capaz de mediar o processo de ensino e aprendizagem, sem desconsiderar as manifestações de criatividade e expressão dos estudantes (NASCIMENTO; LINSINGEN, 2006).

Diferentes pressupostos metodológicos têm sido adotados para promover a perspectiva CTS em sala de aula. Atualmente, há uma gama de trabalhos desenvolvidos utilizando-se essa abordagem, estes trazem consigo o intuito de revisar o ensino de ciências atual e as perspectivas humanas no que diz respeito ao campo da política, economia, questões éticas acerca do desenvolvimento científico e tecnológico (STRIEDER; KAWAMURA, 2008).

Ao se implantar este tipo de abordagem no ensino, deve-se considerar a realidade da qual os estudantes encontram-se inseridos, a fim de que, o tema escolhido para discussão possa abrir espaço para se tornar parte do conhecimento que os alunos precisam adquirir, mesmo que esses conhecimentos não façam parte do currículo, o que se busca com essa proposta são ações que permitam aos estudantes desenvolver uma visão de mundo e dos impactos atuais inerentes a este (SANTOS, 2007).

Ao serem indagados acerca das atividades que foram propostas ao longo do curso, "Educação em Geologia", os docentes expuseram os seguintes comentários:

\footnotetext{
"Aquela atividade do, de calcular o tempo geológico, aquela atividade eu achei muito legal, eu gostei muito, porque tem coisas assim que você vê a diferença de tempo que dá do primeiro pra o outro, e do surgimento da vida e depois vem os outros tudo rapidinho, assim, considerando no período de um ano, então eu achei muito interessante, eu acho que pros alunos fica legal de você visualizar, porque quando você visualiza assim na era todo aquele tempo, você imagina ah, são muitos anos, são milhões de anos, são não sei o que, mas quando você vê assim ele resumido em um ano, você vê a diferença dos eventos, eu achei muito interessante" (SIDERITA).

"A que eu achei a mais interessante, a que eu mais gostei, foi a nossa atividade que falava das teorias, da biogênese, abiogênese, dos seres vivos, pra tentar resgatar toda a formação da Terra, que eu achei assim que deu uma visão mais ampla” (BERILO).
} 
As falas de Siderita e Berilo apontam para o fato de que o professor deve se preocupar não com o conteúdo que está sendo trabalhado, mas também com a forma com que aquele professor vai disponibilizar meios para que os alunos possam adquirir determinado conhecimento. Como apontado por Carvalho e Gil-Peréz (2011), uma das premissas para se ensinar determinada matéria consiste em conhecer os problemas que dificultam a construção do conhecimento científico por parte do discente, além de conhecer os obstáculos e as dificuldades epistemológicas desencadeadas por ele.

Se tratando da Geologia, os alunos possuem muitas dificuldades na compreensão dos assuntos, pois esta é uma área que demanda o desenvolvimento de certas habilidades cognitivas, tais como a visão abstrata e o raciocínio lógico dedutivo, que na maioria das vezes, são desconsiderados pelo professor (TOLEDO, 2005).

Desse modo, as atividades foram pensadas de forma que pudesse fornecer uma visão geocientífica mais completa e sequencial ao professor, para que o entendimento sobre as características e conceitos dos temas possa servir como âncora no ato do planejamento das aulas. Buscou-se também fornecer mediações para que o docente possa impulsionar o processo de ensino e aprendizagem dos estudantes no que tange ao ensino de Geologia.

\footnotetext{
"Eu gostei de tudo, mas o que eu mais gostei foi o enfoque, quando você trouxe pra gente a questão da água, as reportagens, aquilo é bem bacana, é algo que eu gosto de usar muito na sala de aula, reportagem pra que os meninos despertem a curiosidade de assistir e ver um jornal com a família, entender do que se trata aquilo, ler as manchetes, pra que eles vejam o quanto isso faz parte do cotidiano deles né, então eu acho que quando você trouxe as duas reportagens, principalmente da cidade de São Paulo, e a questão das condições da água hoje do planeta né, aquilo pra mim foi muito significativo, foi algo que me agradou bastante, tanto como educadora e como estudante também naquele momento, né, que aquilo traz é um significado pra gente, traz que a gente tem um papel, né, ecológico a ser cumprido né, não adianta eu chegar numa sala de aula e falar e falar e não aplicar em casa [...]. Eles muitas vezes nos veem como um ponto de referência que eles não têm em casa” (QUARTZO).

"Você não ficou só apresentando, por exemplo, no encontro presencial você não só
apresentou, mas durante o curso, nós que produzimos e aí ficou até legal, porque a
imagem lá sobre os tipos de rocha, de formação, posso utilizar depois em sala de
aula, ficou uma coisa rica pra aprendizagem e também depois você pode pegar
aquele material e aplicar em sala de aula" (HALITA).
}

Atenta-se que a proposta do curso não foi priorizar somente o conteúdo ou as práticas, mas sim, realizar uma junção destes dois aspectos, oportunizando mecanismos para que o 
docente participante possa utilizar essas atividades em outros momentos nas aulas de ciências, como é evidenciado na fala de Halita e Quartzo. Além de fazê-lo refletir sobre os modos de aplicação de determinado tema e/ou estratégia, como adaptá-la dependendo do público, qual conceito focar e quais problemáticas levar em consideração para discussão.

\subsubsection{A educação a distância como uma modalidade de formação continuada}

Para aplicação do curso de formação continuada: "Educação em Geologia", optamos pela modalidade de educação a distância como um dos meios de efetivação da proposta. A justificativa na adoção deste tipo de modalidade, como já apontado no embasamento teórico desta investigação, se deu por estarmos interessados em trazer uma contribuição aos docentes, sem que para isto fosse necessário intervir na rotina pessoal e profissional de cada participante envolvido.

Além disso, estudos recentes como os de Pedrosa (2003) e Pereira, Laranja e Fidalgo (2012), apontam a eficácia da educação a distância na base educacional e no advento de vários cursos voltados para a formação profissional de muitos estudantes, sejam eles do âmbito da licenciatura ou não. Pensando por esse viés e, na aproximação do docente com os recursos tecnológicos disponibilizados no cerne mundial atualmente, a proposta teve caráter semipresencial, no qual foram desenvolvidas atividades na plataforma AVA e presenciais.

Para tanto, nesta categoria encontram-se elencadas as concepções dos participantes acerca da educação a distância como uma modalidade que contribui para o provimento dos cursos de formação continuada. Sendo assim, os docentes expuseram as seguintes concepções:

“A educação a distância é muito complicada, difícil! Não falo difícil, é porque você tem que ter uma disciplina, de todo dia olhar, analisar e seguir a proposta, o que muitas vezes pra nós no dia-a-dia é uma correria porque ah eu tenho que fazer isso, ah, mas eu tenho que estudar isso não, mas, isso eu posso entregar daqui há dois dias, aí chega um dia antes, meu Deus eu tenho que fazer, não fiz! Então você tem que ter uma organização, entretanto, eu vejo que é a melhor forma que tem para atingir os professores, porque às vezes o professor tá aqui, ai vamos supor, vamos lá em Planaltina assistir uma aula, o deslocamento daqui até lá, às vezes não é tão fácil para o professor, então pelo menos a educação a distância chega a noite, senta, tem que ser todo dia, começa a ler, estudar, se preparar, então apesar do presencial 
obrigar você a tá na sala de aula presencialmente, não necessariamente você vai tá mentalmente presencial, mas fisicamente você tá lá olhando pro professor, e cê fala cumpri minha parte, estou aqui, não levei falta, na distância eu vejo que exige mais o seu raciocínio, a sua parte mental, intelectual, o físico você deixa lá, ninguém sabe se você tá ou não, o computador tá ligado na plataforma e tá lá marcando que você tá acessando e tá o dia inteiro ainda não nesse caso você tem que escrever, participar do fórum, entendeu? Isso que é interessante" (BERILO).

$\mathrm{Na}$ concepção levantada por Berilo o aluno na $\mathrm{EaD}$ necessita ter autonomia e disciplina para gerenciar o seu próprio processo de ensino e aprendizagem. Esse exercício do aprendiz é que vai incitá-lo a planejar os horários de estudos e a explorar os conteúdos. Conforme Couto (2006), o professor ao assumir o papel de aluno em cursos de formação da $\mathrm{EaD}$ necessita ser autônomo, orientando seu aprendizado por meio de uma análise crítica de suas práticas e dos resultados obtidos em sala, sendo o responsável pela sua desenvoltura dentro do processo de ensino. Sem uma ampla organização, a rotina do aluno fica ameaçada e este corre o risco de acumular tarefas, não as cumprindo dentro do prazo desejável.

Pedrosa (2003, p. 9) destaca que a EaD "responde à proposta de um modelo pedagógico alternativo, que tem por objetivo abrir o acesso à informação aos que desejam aprender". Além de permitir o acesso, esta visa ainda quebrar as barreiras de tempo, espaço e de recursos financeiros que costumam surgir ao se pensar na formação continuada. Pontos esses destacados por Berilo, quando este aponta que a EaD é uma das modalidades de ensino que mais poderá contribuir para que os docentes possam dar prosseguimento em sua formação.

Uma das características apontadas pelos participantes como obstáculo para a realização da formação continuada foi o fator tempo. Fluorita, por exemplo, afirmou que o tempo na $\mathrm{EaD}$ auxilia na organização das tarefas em paralelo com outras obrigações profissionais:

"Eu acho que a educação a distância na formação continuada, ela auxilia nessa questão do tempo principalmente, porque talvez se o curso fosse todo presencial dificultaria a minha participação, por exemplo, já que eu trabalho também, e ai eu acho que a educação a distância ela vem pra facilitar essas questões, não que seja fácil a educação a distância, mas pra você se adaptar àquilo que você está estudando, você fazer seu próprio tempo, então se você tem um tempo você vai lá e faz a leitura de um texto que foi colocado na plataforma, adianta uma atividade, então você vai fazer o seu próprio tempo de estudo, que é como tem que ser né, você que tem que 
direcionar, não tem que ser sempre alguém te direcionando, você também né, tem criar os meios pra você se adequar" (FLUORITA).

A EaD deve disponibilizar espaços para que os professores possam ter acesso a base de conhecimentos, seja ela inicial ou continuada. De acordo com Pedrosa (2003), essa modalidade de ensino deve oportunizar acesso não só aos professores próximos aos polos ou centros de difusão da informação, mas também àqueles que não dispõem de condições, sejam elas financeiras ou até mesmo temporais, para dar prosseguimento em sua formação.

Na concepção de Galena, um curso de formação de professores utilizando somente a modalidade da $\mathrm{EaD}$ não é pertinente. Isso porque, de acordo com a docente, a formação profissional requer momentos que privilegiem a teoria e a prática:

"Pra ser bem sincera? Eu acho assim, eu acho que a educação a distância ela é boa
em certos momentos, eu acho que tem coisas que você pode e consegue fazer a
distância, mas, eu acho que quando é um curso com professor, eu acho que precisa
ser um pouco mais presencial, pode até ter uma parte a distância né, um momento a
distância, uma semana e tal, mas ele tem que ter uma parte presencial, no caso do
seu curso, por exemplo, a gente teve dois encontros, o curso foi pequeno, então eu
acho que dois encontros foi satisfatório, então eu acho que a educação a distância ela
é importante, ela tem o seu papel e o um papel muito importante, principalmente
hoje, eu acho que não desfavorece em nada num curso presencial, mas eu acho que
tem coisas que precisam ser presencial, porque eu preciso pegar, eu preciso ver, e às
vezes só a teoria, porque eu acho que a educação a distância ela é muita teoria, eu
acho que a teoria é legal a distância, mas eu acho que a prática , por isso que eu
penso que pra professor às vezes você necessite de encontros presenciais, não só a
distância [...] Então eu acho que os cursos de educação a distância eles tem a sua
importância e eles não desmerecem em nada pros cursos presenciais, mas eu acho
que a presença para o curso de professores, de licenciatura, eu acho muito
importante" (GALENA).

Diante da dificuldade de muitos alunos se adaptarem com a EaD Moran (2002), apresenta uma série de sugestões que podem ser implantadas a fim de fortificar a sua metodologia nos diversos cursos a distância. Este enseja que os primeiros momentos de curso deveriam ter uma carga horária maior do que a habitual, oportunizando a realização de mais encontros presenciais e vídeo-aulas. Ao lidar com essa transição entre o presencial e o on-line, o aluno estaria mais bem preparado para enfrentar os desafios, aprenderia a gerenciar o seu tempo e a cultivar a autonomia, característica indispensável para o perfil do aluno da EaD. 
Outra questão apontada por Moran (2002), indispensável no planejamento de cursos a distância com foco na formação de professores, consiste em alavancar a produção dos conteúdos a serem trabalhados, a exposição destes deve prioritariamente ser atrelada a atividades significativas passíveis de serem utilizadas em sala de aula, tais como vídeos, recursos audiovisuais e textos básicos. Foi dentro dessa perspectiva enaltecida, que a proposta desenvolvida e aplicada nesta investigação buscou se firmar, uma vez que se torna necessário inovar, buscando propostas que visem principalmente à formação humanista dos professores que atuam no cenário educacional atual.

Em relação ao manuseio da plataforma moodle, alguns docentes participantes do curso relataram certa dificuldade no início, entretanto, ao irem observando as ferramentas e os recursos disponibilizados para socialização como a sala do cafezinho, fórum de notícias e dúvidas, estes passaram a vivenciar o espaço e a interagir com a plataforma de ensino. Os demais afirmaram já possuir experiência com a plataforma, uma vez que já haviam realizado atividades na mesma em outros momentos.

Vale a pena ressaltar que, antes do início do curso cada participante recebeu um e-mail explicativo contendo: a) orientação acerca do cadastro de usuários para àqueles que nunca haviam acessado a plataforma moodle; b) um documento autoexplicativo informando o procedimento para a realização do login e c) um documento munido do código de inscrição (chave de acesso ao curso), orientando cada participante na realização do seu cadastro.

Ao serem indagados acerca da execução das atividades dentro do prazo estabelecido pelo cronograma do curso, os participantes fizeram as seguintes colocações:

\footnotetext{
"Sim, como eu falei anteriormente, eu me organizei melhor durante algumas semanas do curso, outras não, nas que eu não me organizei, eu atrasei a atividade e não as entreguei no tempo certo, mas foi tudo uma questão de organização do tempo" (TURQUESA).

"Sim, sim, foi possível, até porque as atividades elas tinham o prazo de uma semana pra ser realizada, então dava pra gente poder, hãm, fazer, arrumar o tempo pra poder fazê-las tranquilamente, elas exigiam, elas tinham um certo grau de dificuldade, mas dava pra fazer. O tempo foi adequado" (APATITA).
}

Os participantes levantaram o fator tempo como sendo um dos pontos responsáveis por gerenciar todo processo de ensino e aprendizagem na EaD. Mais do que separar um tempo para cumprimento das tarefas propostas, o aluno na EaD necessita gerenciar os mecanismos que favoreça o aprofundamento e entendimentos sobre as questões lançadas em cada atividade, posto que se tratando do curso de professores, elas foram interpostas objetivando o 
raciocínio crítico e a reflexão sobre como se pode ser trabalhado a Geologia, na realidade de cada professor e aluno.

\subsubsection{Comentários acerca da proposição educativa}

Nesta categoria encontram-se elencadas algumas concepções dos participantes acerca do curso - proposição desta dissertação - do qual os docentes participaram. Foi questionado aos professores acerca da postura do professor-tutor e a atuação dos demais profissionais participantes e, se estes gostariam de deixar registrado alguma crítica, elogio e/ou sugestões para eventuais aplicações do curso "Educação em Geologia".

Em suma, as falas abaixo ilustram que o curso foi satisfatório, atentando-se as premissas necessárias para a formação contínua de professores:

\footnotetext{
“Ótimo, responderam tudo assim no... realmente no tempo o que era correto, as dúvidas que a gente pelo menos eu tinha, as intervenções na própria plataforma também foi satisfatória. [...] eu acho assim, o curso foi bem enriquecedor, ele nos recicla muito como educador, eu acho que deveriam existir mais, com outros temas, e bem focado com aquilo que a gente vivencia na sala de aula [...] Com os cursos você sai do piloto automático, você se recicla constantemente, você reavalia aquilo que você antigamente já fazia, tantas e tantas vezes e você nem percebia o que dava e não dava certo ” (QUARTZO).

"Eu quero deixar um elogio pra você que foi muito dedicada, foi muito presente também, a gente colocava lá no fórum a resposta pros seus questionamentos, você logo respondia embaixo, então quero deixar um elogio pra sua dedicação" (FLUORITA).
}

A fala de Quartzo e Fluorita exprime a importância da atuação do professor tutor, conforme explicitado por Moran (2009), o sucesso de um curso a distância, também é em parte fruto da atuação do professor tutor, este é o mediador responsável pelo estabelecimento do processo de aquisição das informações e por fornecer o apoio desejável aos alunos, estando sempre apto para sanar as dúvidas, bem como incentivar os alunos na execução das tarefas propostas.

Outro ponto que pode ser destacado na fala de Quartzo é a importância do feedback dentro da $\mathrm{EaD}$, esse procedimento de comunicação utilizado para informar a acuidade das 
respostas ou das tarefas realizadas pelos alunos é de extrema relevância e não pode de forma alguma deixar de ser realizado, uma vez que é mediante a esse retorno, que o aluno, modela suas percepções, ampliando sua interação entre os principais atores da EaD (LIMA; ALVES, 2011).

Um dos fatores que foi bastante citado pela maioria dos participantes ao lançar sugestões acerca de aplicações futuras do curso foi a questão do tempo, de acordo com parte dos docentes, as atividades estavam bem elaboradas, mas exigiam elevado grau de dedicação para o cumprimento das propostas na íntegra. Entretanto, ao perceberem que o fator organização tem uma ligação direta com a execução das atividades, ficou evidente que faltou um melhor gerenciamento da postura do aluno, já que a autonomia é a chave do processo na $\mathrm{EaD}$ :

\footnotetext{
"Excelente! Foi troca de experiência, inclusive eu achei bastante interessante ter que entrar no que o outro postou, fazer um comentário do que achou, porque aí inclusive você tem ideia, você aproveita a visão do colega, às vezes sua visão tá aqui, a dele tá um pouco mais pra cá, e isso mostra que você pode também pensar de outro jeito. Eu gostei, adorei, achei muito interessante, a única coisa que eu achei é que o curso poderia ser mais amplo, ter mais tempo pra trabalhar, porque tinha textos lá espetaculares, eram grandes e eu fico lendo, gosto de ler devagar, eu vou lendo, vou marcando, mas eu vejo também que é uma organização minha, eu podia ter feito uma organização melhor de ter visto em outros momentos, procurado sempre, às vezes deixava mais pro final, fora isso foi ótimo.” (BERILO).
}

$\mathrm{O}$ ato de fazer um comentário nas atividades postadas na plataforma pelos colegas foi um dos mecanismos utilizados para promover a interação entre os temas e os alunos durante o curso. Berilo destacou essa ação de forma positiva, pois ele pôde ter acesso a outras visões intrínsecas ao ensino de ciências, mais especificamente ao ensino de Geologia.

Halita aponta o papel do professor tutor em sua fala e o quão significativo foi o formato das atividades, uma vez que estas poderão ser aproveitadas em sala, ao serem trabalhados os tópicos da Geologia:

"Foi competente, porque sempre que surgia qualquer dúvida, sempre tinha alguém pra sanar esse problema é, durante os encontros presenciais eu percebi que todos estavam interagindo, todos participando, de forma totalmente positiva. Em relação ao curso, eu gostei do formato das atividades, igual eu falei você fez ali a atividade, além de você ter aprendido, você também pode aplicar em sala de aula, então eu acredito que foi bacana porque não ficou realmente focando em conceito, mas como você poderia trabalhar esse conceito nas aulas de ciências" (HALITA). 
É importante destacar que a associação entre a teoria e os aspectos metodológicos inerentes ao ensino de Geologia foi umas das premissas adotas ao se planejar o curso para professores. O intuito foi levar os docentes a refletir, angariar conhecimentos, estratégias pedagógicas, visando trabalhar com uma postura e visão diferenciada no ensino de Geologia, a fim de reverter as problemáticas interpostas na prática cotidiana que, na maioria das vezes, dificulta o estabelecimento de um ensino de ciências capaz de aguçar a curiosidade e o intelecto dos estudantes.

\subsection{CAMINHOS PARA REFLEXÃO}

Este quarto e último tópico refere-se à reflexão realizada pela autora da presente investigação acerca da construção da formação profissional e dos aspectos promissores resultantes frente à aplicação do curso de formação continuada "Educação em Geologia".

\subsubsection{A construção da formação profisssional}

As necessidades formativas presentes no ensino requerem uma atenção especial do professor, afinal o público atual - crianças, jovens, adolescentes - já não é mais o mesmo de décadas passadas. São alunos dotados de uma postura crítica e que anseiam por respostas rápidas que vão além de uma simplória veiculação da informação.

O exercício da reflexão acerca da própria postura perante a prática pedagógica ainda é um desafio dentro da docência. As transformações que se esperam no seio educacional só ocorrem à medida que o professor amplia sua consciência acerca da sua própria prática, entretanto, para que a mudança possa ser significativamente sentida, é necessário que a reflexão ultrapasse a situação já estabelecida no cotidiano escolar (PIMENTA, 2006).

Mas, para que a reflexão possa de fato ocorrer, Nóvoa (2009) aponta que se torna imprescindível que o professor esteja ciente de que, essa postura em relação ao seu papel é necessária e precisa ser subsidiada ao longo da vida profissional, adotando-se um olhar crítico, desenvolvendo uma compreensão mútua dos processos que envolvem a sua formação, daquilo que ele, enquanto profissional, sente necessidade de reverter e/ou fortalecer. Sendo assim, a reflexão é um algoritmo essencial dentro de qualquer profissão. Esta é uma das 
primazias essenciais na promoção de melhores condutas e ações desencadeadas dentro do espaço de trabalho.

Apesar da percepção e reflexão ser algo imprescindível no alcance de uma formação pautada na continuidade, muitos profissionais acreditam não sentir necessidade de uma formação mais equiparada, com vistas à ressignificação da didática pedagógica e dos conhecimentos pertencentes às áreas afins da ciência.

Ao realizar o trabalho de campo já evidenciado nesta investigação, foi perceptível o desinteresse de muitos docentes ao conhecerem a proposta, estes consideravam que, apesar das dificuldades encontradas na rotina escolar e do ensino estagnado, este ainda não era o momento propício para integrar grupos ou cursos que estejam focados na formação contínua de profissionais da educação. Essa questão se deve ao fato de, "para que os professores considerem as implicações da pesquisa e examinem criticamente sua atividade docente à luz de tais implicações, estes deverão inserir-se de alguma forma no processo de pesquisa" (VERMA; BEARD, 1981, p. 61).

Essa inserção de acordo com Carvalho e Gil-Pérez (2011), ainda é uma barreira, visto que muitos profissionais ainda não querem se comprometer com o viés de pesquisa, o que leva de fato o ensino a continuar pautado em uma mera transmissão de conhecimentos, distanciada do que as pesquisas em didática propõem atualmente, uma vez que estas sugerem o trabalho com as ciências explorando abordagens do campo social, científico e tecnológico, sem desmerecer a realidade da qual os estudantes estão inseridos.

Ainda segundo Carvalho e Gil-Pérez (2011), o reconhecimento das limitações ao se trabalhar com uma prática que privilegia somente a transmissão de conhecimentos se esbarra nas novas formas de aliar a prática didática que ao considerarem o construtivismo, remota para a necessidade de uma formação de professores embasada na pesquisa com efeito na realidade que estes são integrantes.

Ao se pensar na educação, há que se pensar na necessidade de transformação da realidade enfrentada pelo ensino atual, conforme afirmado por Freire (2000, p. 33), "não estou no mundo para simplesmente a ele me adaptar, mas para transformá-lo; se não é possível mudá-lo sem um certo sonho ou projeto de mundo, devo usar toda possibilidade que tenha para não apenas falar de minha utopia, mas participar de práticas coerentes". Aos docentes cabe então o exercício constante da transformação, da mudança, da prática que estabeleça o formar, o ser, o cidadão, a educação. 


\subsubsection{Aspectos promissores do curso "Educação em Geologia"}

A maioria dos resultados obtidos após a aplicação do curso "Educação em Geologia" vai ao encontro ao que foi apontado por muitos estudiosos nas respectivas literaturas utilizadas para fundamentação do trabalho. Algumas questões apontadas pelos participantes contrapunham as concepções de alguns autores, tais como a elucidação da carga horária e da quantidade de atividades empregadas na realização de cursos de formação continuada. Se tratando da proposta fomentada nesta pesquisa, para aplicações futuras do curso "Educação em Geologia" alguns aspectos deverão ser ponderados, tais como uma maior carga horária e/ou uma melhor adequação das atividades propostas, a fim de melhor redimensionar a execução do curso.

Diante disso, torna-se necessário sugerir então, novas maneiras de pensar ao se tratar de formação continuada de professores. Segundo Nóvoa (1995, p. 11), para que a formação passe a ser tema central dos debates educacionais, é imprescindível reconhecer "as deficiências científicas e a pobreza conceitual dos programas atuais de formação de

professores". Como fora apontado ao longo dos resultados obtidos, há uma carência de cargas horárias presenciais se tratando da $\mathrm{EaD}$. O que não difere do ensino presencial, uma vez que em cursos de licenciatura, também há uma necessidade do aumento de aulas teóricas e práticas, como é o caso da disciplina de Geologia.

Baseando-se nos depoimentos apresentados pelos participantes foi possível apreender ainda que mesmo o curso sendo uma experiência piloto, este forneceu subsídios para que os participantes pudessem vislumbrar a Geologia mediante as características enfatizadas e explanadas ao longo desta investigação, tais como uma ciência interdisciplinar, histórica, interpretativa e promissora no tratamento das questões ambientais (CARNEIRO, 2005, FRODEMAN, 2010; POTAPOVA, 1968; TOLEDO, 2005).

Logo, mesmo adotando-se uma modalidade de ensino que não privilegiava a prática substancial - se tratando da Geologia e do caráter prático que esta deveria fornecer - o curso ofertado adotando-se a $\mathrm{EaD}$ permitiu que os professores desencadeassem uma nova visão planetária e novas percepções em relação a uma educação sustentável, sendo possível ampliar a visão dos docentes envolvidos, instrumentalizando-os no planejamento de aulas e na coleta de informações que envolvam temas de Geologia.

Dentro dessa perspectiva, a produção de saberes desencadeado ao longo do curso buscou evidenciar aspectos intrínsecos ao atualismo e à Geologia como uma ciência que 
busca respostas no presente para os fatos ocorridos no passado. Fomentando que o entendimento da evolução planetária vem favorecer uma abordagem da área em um caráter mais sistêmico, integrado, preocupado com as questões ambientais atuais (TOLEDO, 2005).

Por fim, enseja-se que o que se busca são melhorias a curto prazo na prática educativa do professor, bem como das relações estabelecidas em sala, o que engloba a ordem de aprendizagem dos estudantes frente à Geologia e a inserção destes no campo investigativo, de modo a possibilitar o desenvolvimento de competências e habilidades que os integrem em bases que permitam um enfrentamento e interpretação das dificuldades ancoradas na ordem global. 


\section{CONSIDERAÇÕES FINAIS}

O presente estudo abriu margem para a efetivação de uma proposta de formação continuada com vistas à ressignificação da prática docente. As abordagens contidas na proposta metodológica do curso - proposição da presente investigação - visaram considerar duas dimensões da pesquisa em educação, sendo elas a produção de saberes e a formação contínua de professores de Ciências Naturais.

A produção de saberes esteve centrada nos temas de Geologia, esta que necessita estar continuamente presente nas bases educacionais, uma vez que se busca ir além da construção de uma visão meramente científica, mas também edificar as concepções de ordem planetária, tornando os cidadãos agentes ativos, autores dos processos que possibilitem angariar soluções. Seu ensino deve transpor as Ciências Naturais, uma vez que, o entendimento da ordem ambiental fica a cargo somente dessa disciplina. Logo, a abordagem interdisciplinar constituída nessas esferas, necessita de uma articulação por parte dos docentes, pois é no espaço escolar que os estudantes poderão mobilizar conhecimentos, com vistas às causas mais pertinentes do planeta.

Foi perceptível o quanto os cursos de formação continuada podem contribuir diretamente na resolução de problemáticas identificadas no ensino, como é o caso da Geologia. A intervenção e a inserção de temáticas da área podem ocorrer de forma singular, abordando-se os aspectos provenientes do próprio contexto em que os estudantes encontramse inseridos. As estratégias adotadas no curso fornecem o respaldo inicial para que os docentes possam mediar os temas, possibilitando a discussão da importância do conhecimento geocientífico como uma ciência histórica e interpretativa que, permite contribuir para o alcance de percepções que envolvem o futuro planetário.

A intensificação dos saberes perante a Geologia no curso fornecido, só foi possível por meio da formação continuada. O engajamento dos docentes participantes da proposta executada promove a ressignificação da prática pedagógica, ilustrando a importância do comprometimento do docente com a educação e principalmente com os aspectos holísticos intrínsecos a sua formação. Percebe-se então que a reflexão é uma ação indispensável na construção profissional de professores, uma vez que o entendimento da escola deve centrar na formação e no trabalho como atividades unificadas e não distintas.

Como observado, a proposta de formação continuada delineada na presente investigação esteve firmada na adoção da $\mathrm{EaD}$ para sua execução. Para tanto, salienta-se que 
o avanço da EaD nas bases educacionais e a sua consolidação dentro dos aspectos formativos, o que envolve a viabilização de cursos de formação de professores, requer ainda o avanço em estudos e pesquisas a fim de evidenciar as concepções que poderão ser promissoras, sendo as experiências avaliadas não quantitativamente, mas em caráter qualitativo.

Por fim, salienta-se que a educação a distância pode contribuir para que os professores vençam as barreiras dentro do ensino e intensifiquem o processo de busca pelo saber e pelas ciências da natureza, além de promover uma intensificação dos saberes adquiridos em outros processos de formação do quais os docentes vivenciaram. 


\section{REFERÊNCIAS BIBLIOGRÁFICAS}

ALVAREZ-SUÁREZ, R. La utilización de modelos experimentales en geologia. Science and citizenship education, n. 35, p. 60-69, 2003.

ALARCÃO, I. Contribuição da didáctica para a formação de professores. In: PIMENTA, S. G. Didática e formação de professores: percursos e perspectivas no Brasil e em Portugal. 4 ed. p. 159 - 190. São Paulo, Cortez, 2006.

ANDREWS, S. The Geologist as Detective: a view of our profession. Presented at the annual meeting of the New England Section of the Geological Society of América.1998. Disponível em: http://www.sarahandrews.net/index.htm. Acesso em: 14 de dez. de 2015.

BACCI, D. de L. C. A contribuição do conhecimento geológico para a educação ambiental. Pesquisa em Debate. ed. 11, n. 2, v. 6, jul/dez, 2009.

BARBAtTO, S. Metodologia de Pesquisa Qualitativa. Brasília: Editora UnB, 2008.

BOFF, L. Ecologia, Grito da Terra, Grito dos pobres. São Paulo, Ática, 1996.

BOGDAN, R.C.; BIKLEN, S. K. Características da investigação qualitativa. In. Investigação qualitativa em educação. Uma introdução à teoria e aos métodos. Porto, Portugal: Porto, p. 47-51, 1994.

BOLACHA, E. Elementos sobre epistemologia em Geologia: uma contribuição no Ano Internacional do Planeta Terra. Revista Electrónica de Ciências da Terra. 2008. Disponível em: http//:www.e-terra.geopor.pt. Acesso em: 27 de dez. de 2015.

BRASIL. Decreto $n^{\circ} 5.622$, de 19 de dezembro de 2005. Regulamenta o art. 80 da Lei $n$. 9.394, de 20 de dezembro de 1996, e dá outras providências. Diário Oficial da União, Brasília, DF, 11 fev. 1998.

Ministério da Educação e do Desporto. Referenciais para a Formação de professores. Brasília: MEC / SEF, 2002. Disponível em <http://portal.mec.gov.br/seb/arquivos/pdf/public/reformprof4.pdf>. Acesso em: 04 jan. 2015.

Ministério da Educação. Conselho Nacional de Educação. Parecer CNE/CEB n. 11/2010, de 7 de julho de 2010. Diretrizes Curriculares Nacionais para o Ensino Fundamental de 9 anos. Brasília, DF: CNE/CEB, 2010. 
Parâmetros curriculares nacionais: terceiro e quarto ciclos: apresentação dos temas transversais/Secretária de educação fundamental. Brasília: 1998.

Reforma do Projeto Político Pedagógico do Curso de Licenciatura em Ciências Naturais - Diurno. Brasília, DF, jan. 2013.

. Senado Federal. Lei de Diretrizes e Bases da Educação Nacional: nº 9394/96. Brasília: 1996.

BYBEE, R. W. Science education and the science-technology-society (STS) theme. Science Education, n. 5, v. 71, p. 667-683, 1987.

CARNEIRO, C. D. R.; SANTOS, G. R. B. dos. Ensino de geociências na formação profissional em meio ambiente no estado de São Paulo. Revista Brasileira de Geociências, São Paulo, p. 84-95, dez. 2012.

CARNEIRO, C. D. R.; TOLEDO, M. C. M. D.; ALMEIDA, F. F. M. D. Dez Motivos para a Inclusão de Temas de Geologia na Educação Básica. Revista Brasileira de Geociências, São Paulo, n. 4, v. 34, p.553-560, dez. 2004.

CARNEIRO, C. D. R..; GONÇALVES, P. W.; NEGRÃO, O. B. M.; CUNHA, C. A. L. Ciência do Sistema Terra e o entendimento da "máquina" planetária em que vivemos. Geonomos, v, 13(1). p, 11-18. 2005.

CARVALHO, A. M. P. de C.; GIL-PÉREZ, D. Formação de professores de ciências: tendências e inovações. 10 ed. 127 p. São Paulo: Cortez. 2011.

CARVALHO, R. C. Análise preliminar de complicadores na aprendizagem em geociências: um olhar sobre os estudantes de ciências naturais da Universidade de Brasília. 2013. 37 p. Trabalho de Conclusão de Curso (Licenciatura em Ciências Naturais) - Faculdade UnB Planaltina, Universidade de Brasília.

CHARPAK, G. As ciências na escola primária. Uma proposta de acção. Lisboa. Editorial Inquérito, 1996.

COMPIANI, M. Geologia/geociências no Ensino Fundamental e a formação de professores. Geologia. USP Publ. Especial, São Paulo, v 3, p. 13-30, setembro de 2005. 
COSTA, S. A. O reconhecimento das geociências na educação básica: uma proposta de material pedagógico para professores do distrito federal. 2013. 75 p. Trabalho de Conclusão de Curso (Licenciatura em Ciências Naturais) - Faculdade UnB Planaltina, Universidade de Brasília.

COUTO, M. S. A educação a distancia (EaD): características e estruturação de um curso de formação continuada de professores. Revista E-Curriculum, São Paulo, v. 2, n. 3, dez. 2006.

CRESPÍ, J. V.; GONZÁLEZ, M.; BARRENO, J. V. Moodle, una nueva herramienta para la enseñanza de la geologia. Enseñanza de las Ciencias de la Tierra, Espanha, p. 54-61, 2006.

CUNHA, A. M. O.; KRASILCHILK, M. A formação continuada de professores de ciências: percepções a partir de uma experiência. 29a reunião anual anped, Caxambu, 2000.

DELIZOICOV, D.; ANGOTTI, J. A.; PERNAMBUCO, M. M. Ensino de ciências fundamentos e métodos. 4 ed. São Paulo: Cortez, 2011. 364p.

DESGAGNÉ, S. La position du chercheur en recherche collaborative: illustration d'une démarche de médiation entre culture universitaire et culture scolaire. Recherches qualitatives, v. 18, p. 77-105, 1998.

DRIVER, R.; ASOKO. H.; LEACH. J.; MORTIMER. E.; SCOTT. P. S. Construindo conhecimento científico na sala de aula. Química Nova na Escola, n. 9, p. 31-40, 1999.

DUARTE, R. Entrevistas em pesquisas qualitativas. Editora UFPR. Educar, Curitiba, n. 24, p. 213-225, 2004. Disponível em: http://www.scielo.br/pdf/er/n24/n24a11.pdf. Acesso em: 17 de nov. de 2015.

ELLIOT, J. El cambio educativo desde la investigacioón-ación. Madri: Morata, 1993.

ENGELHARDT, W.; ZIMMERMANN, J. Theory of Earth Science. Cambridge University Press, Cambridge. 1988.

FARIA, F. O Atualismo entre uniformitaristas e catastrofistas. Revista Brasileira de História da Ciência, Rio de Janeiro, v. 7, n. 1, p. 101-109, jan. jun. 2014.

FAZENDA, I, C, A. Didática e interdisciplinaridade. Campinas, São Paulo: Papirus, 1998. 
FIGUEIRÔA, S. F. M. história e filosofia das geociências: relevância para o ensino e formação profissional. Terra e Didatica, ed. 5, v. 1, p. 63-71, 2009.

FÓRUM GLOBAL 92. Tratados das ONGs aprovados no Fórum Internacional das Organizações Não Governamentais e Movimentos Sociais no âmbito do Fórum Global ECO 92. Rio de Janeiro: Fórum das ONGs. 1992.

FREIRE, M. A formação permanente. In: FREIRE, P. Trabalho, comentário, reflexão. Petrópolis, RJ: Vozes, 1991

FREIRE, P. Pedagogia da autonomia: saberes necessários à prática educativa, São Paulo: Paz e Terra, 1996.

UNESP, 2000.

Pedagogia da Indignação: cartas pedagógicas e outros escritos. São Paulo:

Pedagogia do oprimido, 17. ed. Rio de Janeiro: Paz e Terra, 1987.

FRODEMAN, R. O raciocínio geológico: a geologia como uma ciência interpretativa e histórica. Terra e Didática, ed. 6. v. 2. p. 85-99, 2010.

GADOTTI, M. Pedagogia da terra: Ecopedagogia e Educação Sustentável, 6 ed. São Paulo: Peirópolis, 2009.

GALVÃO, D. M.; FINCO, G. Geociências no ensino médio: aprendendo para a cidadania. VII Enpec - Encontro Nacional de Pesquisa em Educação em Ciências. Florianópolis, 8 de novembro de 2009. ISSN: 21766940.

GARRIDO, E. Por uma nova cultura escolar: o papel mediador do professor entre a cultura do aluno e o conhecimento elaborado. In: GARRIDO, E. (Org.). Conhecimento, pesquisa e educação. Campinas: Papirus, p. 125-142, 2001.

GASKELL, G. Entrevistas Individuais e Grupais. In: BAUER, M. W.; GASKELL, G.; ALLUM, N. C. Pesquisa qualitativa com texto, imagem e som: um manual prático. $2^{\mathrm{a}}$ edição, p. 17 - 36. Petrópoles, RJ: Editora Vozes, 2002.

GERMAIN, C. Interdisciplinarité et globalité: Remarques d'ordre épistémologique. Revue des Sciences de l'Éducation XVII(I), p. 142-152, 1991. 
GIOLLO, J. A educação a distância e a formação de professores. Educ. Soc. Campinas, n. 105, v. 29, p. 1211-1234, set./dez. 2008.

GONÇALVES, J. A. M. Vidas de professores. Porto: Porto, p. 141-169, 1992.

GONÇALVES, P.W.; SICCA, N. A. L. O que os professores pensam sobre geociências e Educação Ambiental? (levantamento exploratório de concepções de professores de ribeirão preto, SP). Revista do Instituto de Geociências - USP, v. 3, p. 97-106. 2005.

HEVIA, I. M. La dinámica de sistemas complejos en las ciencias de la tierra y del medio ambiente. Enseñanza de las Ciencias de la Tierra, n. 1, v. 17, p. 26-36, 2009.

HOLMBERG, B. Educación a distancia: situación y perspectivas. Buenos Aires: Editorial Kapeluz, 1977.

IBIAPINA, I, M, L de M. Pesquisa colaborativa: investigação, formação e produção de conhecimentos. Brasília: Líber Livro Editora. 136 p. 2008.

IMBERNON, R, A, L.; GUIMARÃES, E, M.; GALVÃO, R, de M.; LIMA, A, C, de.; SANTIAGO, L, F.; JANNUZZI, C, M L. Um panorama dos cursos de licenciatura em ciências naturais (LCN) do Brasil a partir do $2^{\circ}$ seminário brasileiro de integração de cursos deLCN/2010. Experiências em Ensino de Ciências. UFRGS, v. 6, p. 85-93, 2011.

JANTSCH, A. P.; BIANCHETTI, L. (org.). Interdisciplinaridade: para além da filosofia do sujeito. Petrópolis: Vozes. 204 p, 1995.

JUSTINA, R. D. Parceria. In: Dicionário em construção: interdisciplinaridade. (Org). FAZENDA, I. C. A. 2 ed. p. 160-162. São Paulo: Cortez, 2002.

KASTENS, K, A.; MANDUCA, C, A.; CERVATO, C.; FRODEMAN, N.; GOODWIN, C.; LIBIEN, L. S.; MOGK, D. W.; SPANGL, T. C.; STILL INGS, N. A. Titus How Geoscientists Think and Learn Eos, n. 31, v. 90, 2009.

KEEGAN, D. Foundations of distance education. $2^{\text {a }}$ ed. Londres: Routledge, 1991.

KRASILCHILK, M. Inovação no ensino das ciências. In: GARCIA, W. E. (Org.). Inovação educacional no Brasil: problemas e perspectivas. São Paulo: Cortez; Campinas: Autores Associados, p. 164-180, 1980. 
LAVILLE, C.; DIONNE,J. A construção do saber: manual de metodologia da pesquisa em ciências humanas. Porto Alegre: Editora Artes Médicas Sul Ltda; Belo Horizonte: Editora UFMG, 1999.

LIMA, D. M. de. A e.; ALVES, M. N. O feedback e sua importância no processo de tutoria a distância. Pro-Posições, Campinas, v. 22, n. 2, maio/ago. p. 189-205, 2011.

LÜDKE, M.; ANDRÉ, M. E. D. A. Pesquisa em Educação: Abordagens Qualitativas. São Paulo: EPU, 1986.

MAGALHÃES JÚNIOR, C. A. O.; M. PIETROCOLA. Atuação de professores formados em licenciatura plena em ciências. Revista de Educação em Ciência e Tecnologia, n.1, v.4, p. 175-198, 2011.

MAGALHÃES, S.; TENREIRO-VIEIRA, C. Educação em ciências para uma articulação Ciência, Tecnologia, Sociedade e pensamento crítico. Um programa de formação de professores. Revista Portuguesa de Educação, n. 2, v.19, p. 85-110, 2006.

MANZINI, E. J. Entrevista semi-estruturada: análise de objetivos e de roteiros. Em: Seminário Internacional de Pesquisa e Estudos Qualitativos. In: MANZINI, E, J. (Org.). A pesquisa qualitativa em debate. Anais. Bauru: SIPEQ, 2004.

MARTINS, J. R. S.; CARNEIRO, C. D. R. Contribuições do ensino de geociências à formação de uma massa crítica de professores e investigadores. Revista Terra e Didática, n.10, v. 03, p. 368-377, 2014.

MATTHEWS, M. R. History, Phylosophy and Science teaching: a reapprochement. Studies in Science Education, n. 18, P. 25-51, 1990.

MORAN, J. M. Aperfeiçoando os modelos de EaD existentes na formação de professores. Educação, Porto Alegre, v. 32, n. 3, p. 286-290, set./dez. 2009.

MORAN, J. M. O que é educação a distância. Rio de Janeiro. 2002. Disponível em: http://www2.eca.usp.br/moran/wp-content/uploads/2013/12/dist.pdf. Acesso em: 17 de dez. de 2015.

MORIN, E. Educação e complexidade: os sete saberes e outros ensaios. São Paulo: Cortez, 2002. 
MORIN, E.; CIURANA, E-R.; MOTTA, R. D. Educar na era planetária o pensamento complexo como método de aprendizagem no erro e na incerteza humana. São Paulo. Editions Balland, 2003.

NASCIMENTO, D. S. Abordagem dos temas de Geociências no $6^{\circ}$ ano no Ensino Fundamental do Distrito Federal: análise dos temas em livros didáticos, conhecimento dos alunos e recursos utilizados pelos professores do DF. 2011.48 p. Trabalho de Conclusão de Curso (Licenciatura em Ciências Naturais) - Faculdade UnB Planaltina, Universidade de Brasília.

NASCIMENTO, T. G. N.; LINSINGEN, I. V. Articulações entre o enfoque CTS e a pedagogia de Paulo Freire como base para o ensino de ciências. Convergencia.

Universidaded Autônoma del Estado de México. set/dez. v. 13, n. 42. Toluca, México. P. 95116, 2006.

NÓVOA, A. Formação de professores e profissão docente. In: NÓVOA, A. (org.) Os professores e a sua formação. Lisboa: Publicações Dom Quixote. p. 13-33, 1995.

Imagens do futuro presente. Lisboa, Portugal: EDUCA, 2009.

Para uma formação de professores construída dentro da profissão. Revista

Educación. Madrid, n. 350, p. 203-218, set/dez. 2009.

NUNES, M. A. A.; IBIAPINA, L. de M. Uma Pesquisa Colaborativa de Práticas

Pedagógicas Direcionadas a Adolescentes Privados de Liberdade. p. 1-12, 2008.

PEDRINACI, E. Alfabetización en Ciencias de la Tierra, una propuesta necesaria. Enseñanza de las Ciencias de la Tierra. n. 2, v. 20, p. 133-140, 2012.

PEDROSA, S. M. P. de A. A educação a distância na formação continuada do professor. Educar, Curitiba, n. 21, p. 67-81, 2003.

PEREIRA, A. G.; LARANJO, J de C.; FIDALGO, F. S. R. Formação continuada de professores e EaD: superação de limites e limites da superação. SIED - Simpósio Internacional de Educação a Distância. EnPED - Encontro de Pesquisadores em Educação a Distância. Universidade Federal de São Carlos. Set. 2012.

PIAGET, J. Psicogía y pedagogia. Barcelona: Ariel, 1969. 
PIMENTA, S. G. Formação de professores: identidades e saberes da docência. Nuances Faculdade de Educação - USP. v. III, São Paulo, Brasil, set. 1997.

Para uma res-significação da didática. In: PIMENTA, S. G. Didática e formação de professores: percursos e perspectivas no Brasil e em Portugal. 4 ed. p. 159 - 190. São Paulo, Cortez, 2006.

Pesquisa-ação crítico-colaborativa: construindo seu significado a partir de experiências com a formação docente. Educação e Pesquisa. São Paulo, n. 3, v. 31, p. 521539, set./dez. 2005.

Professor pesquisador: mitos e possibilidades. Contrapontos, n. 1, v. 5, p. 09-22, jan./abr. 2005.

POTAPOVA, M. S. Geology as an historical science of nature. In: Interaction of sciences in the study of the Earth. Moscou: Progress Publisher. p. 117-126, 1968.

PRESS, F.; SIEVER R..; GROTZINGER, J.; JORDAN, T. H. Para Entender a Terra. Tradução Rualdo Menegat, 4 ed. - Porto Alegre: bookman, 656 p. 2006.

REIGOTA, M. O que é educação ambiental. São Paulo: Brasiliense, 1994.

SANTOS, W. L. P. dos. Educação científica: na perspectiva de letramento como prática social: funções, princípios e desafios. Revista Brasileira de Educação, n. 36, v. 12, set./dez., p. 474-492, 2007.

SANTOS. W, L, P.; MORTIMER. E, F. Uma análise dos pressupostos teóricos da abordagem C-T-S (Ciência - Tecnologia - Sociedade) no contexto da educação brasileira. Ensaio.

Pesquisa em Educação, n. 2, v. 2, p. 1-23, 2002.

SCHNETZLER, R. P. Como associar ensino com pesquisa na formação inicial e continuada de professores de Ciências? Atas do II Encontro Regional de Ensino de Ciências. Piracicaba: UNIMEP, 18-20 out, 1996.

SICCA, N, A, L.; GONÇALVES, P, W.; FERNANDES, M, C, da, S, G.; CANEIN, M, B, de, S.; SANTOS, M, J, dos.; FIGUEIREDO, R, L. Interfaces currículo do ensino médio e geociências: 10 anos de reflexão de grupo de pesquisa colaborativa. Terra e Didatica, n.10, v. 03, p. 357-367, 2014. 
SIGNORETTI, V. V.; CARNEIRO, C. D. R. As geociências e as tecnologias de informação e comunicação (TICs) na interface ensinar-aprender. Terra e Didatica, n. 3, v. 10, p. 466-473, 2014.

SILVA, G, F. Educação Ambiental na Escola. Monografia de Pós-Graduação, FIJ Faculdades Integradas de Jacarepaguá, 2009.

SILVA, R. R.; MACHADO, P. F. L.; TUNES, E. Experimentar Sem Medo de Errar. In: Ensino de Química em foco. (Org.). SANTOS, W. L. P.S.; MALDANER, O. A. Ijuí: Editora Unijuí, p. 231-261. 2010.

STRIEDER, R.; KAWAMURA, M. R. Abordagem CTS no contexto escolar: reflexões a partir de uma intervenção. XI Encontro de Pesquisa em Ensino de Física. Curitiba. p. 1-13. 2008.

TARDIF, M. Saberes profissionais dos professores e conhecimentos universitários. Revista Brasileira de Educação. n. 13, p. 5-24, jan, fev, mar, abr, 2000.

TARDIF, M.; GAUTHIER, C. Pour ou contre un ordre professionnel des enseignantes et des enseignants au Québec. Quebec: Les Presses de l’Université Laval. 1999.

THIESEN, J. S. A interdisciplinaridade como um movimento articulador no processo ensinoaprendizagem. Revista Brasileira de Educação, n. 39, v. 13, set/dez. 2008.

TOLEDO, M. C. M. Geociências no Ensino Médio Brasileiro - Análise dos Parâmetros Curriculares Nacionais. Revista do Instituto de Geociências - USP, Publ. Espec. v. 3, p. 3144, set, 2005.

VERMA, G. K.; BEARD, R. M. What is educational research? Londres: Gower, 1981

WESTBROEK, P. Earth System Science and Gaia. Disponível em: <www2.sescsp.org.br/sesc/.../peter_westbroek.doc> Acesso em: 18 de Jan. de 2015.

ZABALA, A.; ARNAU, L. Como aprender e ensinar competências. Porto Alegre: Artmed, 2010.

ZANOTTO, M. A. do C.; ROSE, T. M. S. de. Problematizar a própria realidade: análise de uma experiência de formação contínua. Educação e Pesquisa, São Paulo, v.29, n.1, p. 45-54, jan./jun. 2003. 
ZEICHNER, K. M. Uma análise crítica sobre a 'reflexão' como conceito estruturante na formação docente. Educação e Sociedade, n. 103, v. 29, p. 535-55, 2008. 
APÊNDICE A - Termo de Consentimento Livre e Esclarecido

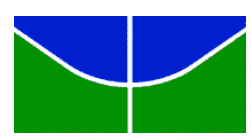

\section{UNIVERSIDADE DE BRASÍLIA}

Programa de Pós-Graduação em Ensino de Ciências

Mestrado profissionalizante em Ensino de Ciências

\section{Termo de Consentimento Livre e Esclarecido (TCLE)}

Você está sendo convidado (a) para participar da pesquisa "Formação Continuada a Distância para o Professor de Ciências Naturais do Ensino Fundamental: Educação em Geologia" de responsabilidade de Samara dos Anjos da Costa, aluna do Programa de PósGraduação em Ensino de Ciências da Universidade de Brasília, sob orientação da Professora Dr. ${ }^{a}$ Alice Melo Ribeiro e coorientação da Professora Geóloga Anete Maria de Oliveira.

A pesquisa tem como objetivo realizar um estudo acerca do ensino de geologia, com professores de Ciências Naturais atuantes no Ensino Fundamental da educação básica. A coleta de dados será feita por meio de entrevista individual, com auxílio de roteiro prévio.

Com base nessas informações espera-se identificar obstáculos, caso existam, ao Ensino de Geociências e em parceria, professores-pesquisadores, propor sugestões e desenvolver atividades que auxiliem a prática pedagógica em sala de aula, dentre elas, um curso de formação continuada na modalidade a distância, como também avançar nas pesquisas com relação à formação continuada de professores.

A sua contribuição é muito importante e, em qualquer etapa do estudo, você terá acesso aos pesquisadores para esclarecimento de eventuais dúvidas.

As informações obtidas serão analisadas em conjunto com outros sujeitos da pesquisa, não sendo divulgada a identificação de nenhum participante. Fica assegurado, também, o seu direito às informações sobre os resultados parciais da pesquisa.

Não há despesas pessoais para a sua participação em qualquer fase do estudo, nem tão pouco compensação financeira. Se existir qualquer despesa, ela será absorvida pelo orçamento da pesquisa.

Explicitamos ainda que a execução da pesquisa será utilizada exclusivamente para fins acadêmicos.

É garantida aos sujeitos da pesquisa a liberdade da retirada de consentimento e o abandono do estudo a qualquer momento.

$\mathrm{Eu}$, declaro ter sido informado(a) e concordo em participar, como voluntário(a) da pesquisa acima descrita.

Brasília 2015

Para contato:

Samara dos Anjos da Costa (Mestranda e Pesquisadora), telefone: (61) 9558-3678 ou (61) 9682-1050, e-mail: samaraanjoos@gmail.com; Alice Melo Ribeiro (Orientadora e Pesquisadora), telefone: (61) 3107- 2907, e-mail: alice.ribeiro.unb@gmail.com; Anete Maria de Oliveira (Colaboradora e Pesquisadora), telefone: (61) 8111-4967, e-mail: anetemoliveira@gmail.com 
APÊNDICE B - Roteiro da entrevista semiestruturada (Pesquisa Inicial)

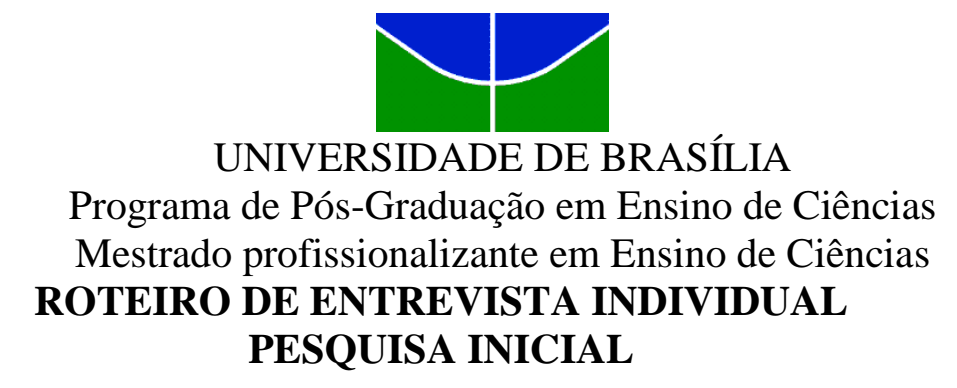

Nome: Escola: Data:

1. Qual é a sua formação acadêmica (que curso, onde estudou e quando formou)?

2. Qual é o seu tempo de experiência na Secretária de Educação (em especial no Ensino Fundamental)?

3. Durante a sua formação acadêmica, você obteve contato com alguma disciplina no âmbito da Geologia? Qual (is)?

4. Em quais outros momentos você teve contato com as temáticas da Geologia?

5. Qual a importância em compreender a dinâmica do planeta para contribuir na resolução dos impactos ambientais?

6. Quais são as dificuldades e/ou facilidades encontradas por você ao trabalhar os temas da Geologia previstos no currículo educacional?

7. Quais estratégias de ensino e/ou recursos didáticos você utiliza no ensino de temáticas de Geologia?

8. Quais estratégias de ensino e/ou recursos didáticos você acredita que poderiam contribuir significativamente para uma abordagem pedagógica mais efetiva se tratando das temáticas de Geologia?

9. Qual o seu grau de aproximação com os recursos tecnológicos, entre eles computador, acesso a websites e outros?

Você deseja acrescentar algo que não foi mencionado no decorrer da nossa conversa?

\section{Obrigada pela atenção!}

Samara dos Anjos da Costa

Contato: samaraanjoos@gmail.com 
APÊNDICE C - Roteiro da entrevista semiestruturada (Pesquisa Avaliativa)

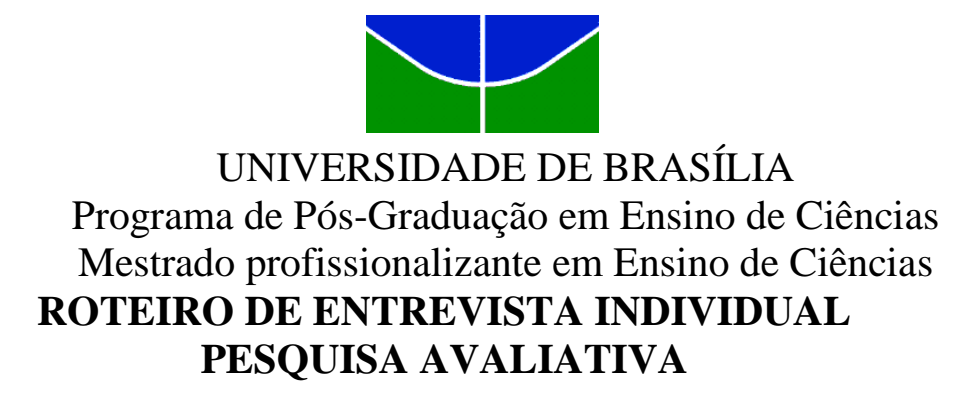

Nome:

Escola:

Data:

1. Em sua opinião, qual a importância dos cursos de formação continuada para o professor?

2. Qual o principal impacto que a formação continuada proporciona na prática pedagógica?

3. Você acredita que cursos de formação continuada instrumentalizam o professor a agregar os conhecimentos apreendidos durante a participação nesse tipo de ação, àqueles adquiridos em outros momentos de sua formação?

4. A proposta executada atendeu suas expectativas em relação à formação docente atrelada aos assuntos mais pertinentes da Geologia?

5. Os conteúdos ministrados e trabalhados ao longo do curso atenderam às suas perspectivas profissionais?

6. O curso oferece condições para que o professor possa trabalhar o ensino de Geologia nas aulas de Ciências Naturais baseando-se em uma concepção ambiental e interdisciplinar?

7. As atividades e estratégias didáticas foram trabalhadas satisfatoriamente?

8. Em relação ao mecanismo adotado para efetivação do curso, como você avalia a adoção da modalidade de Educação a Distância $(\mathrm{EaD})$ como modalidade utilizada na formação continuada?

9. Você teve alguma dificuldade ao manusear a plataforma AVA - moodle durante sua participação no curso?

10. Os encontros virtuais e os encontros presenciais permitiram que você, professor, pudesse flexibilizar o tempo, executando as atividades dentro do prazo estabelecido?

11. Como você avalia a postura do professor-tutor e a atuação dos demais profissionais participantes? 
12. Você gostaria de deixar registrado alguma crítica, elogio e/ou sugestão para aplicações futuras do curso de "Educação em Geologia"?

Você deseja acrescentar algo que não foi mencionado no decorrer da nossa conversa?

\section{Obrigada pela atenção!}

Samara dos Anjos da Costa

Contato: samaraanjoos@gmail.com 
APÊNDICE D - Proposição de Intervenção Educativa

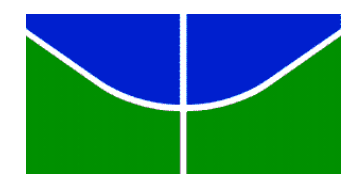

UNIVERSIDADE DE BRASÍLIA - UnB

Instituto de Ciências Biológicas

Instituto de Física

Instituto de Química

Faculdade UnB Planaltina

Programa de Pós-Graduação em Ensino de Ciências

Mestrado Profissional em Ensino de Ciências

\section{"EDUCAÇÃO EM GEOLOGIA"}

Autor (a): Samara dos Anjos da Costa

Ilustrações: Stefanne Souza Laia

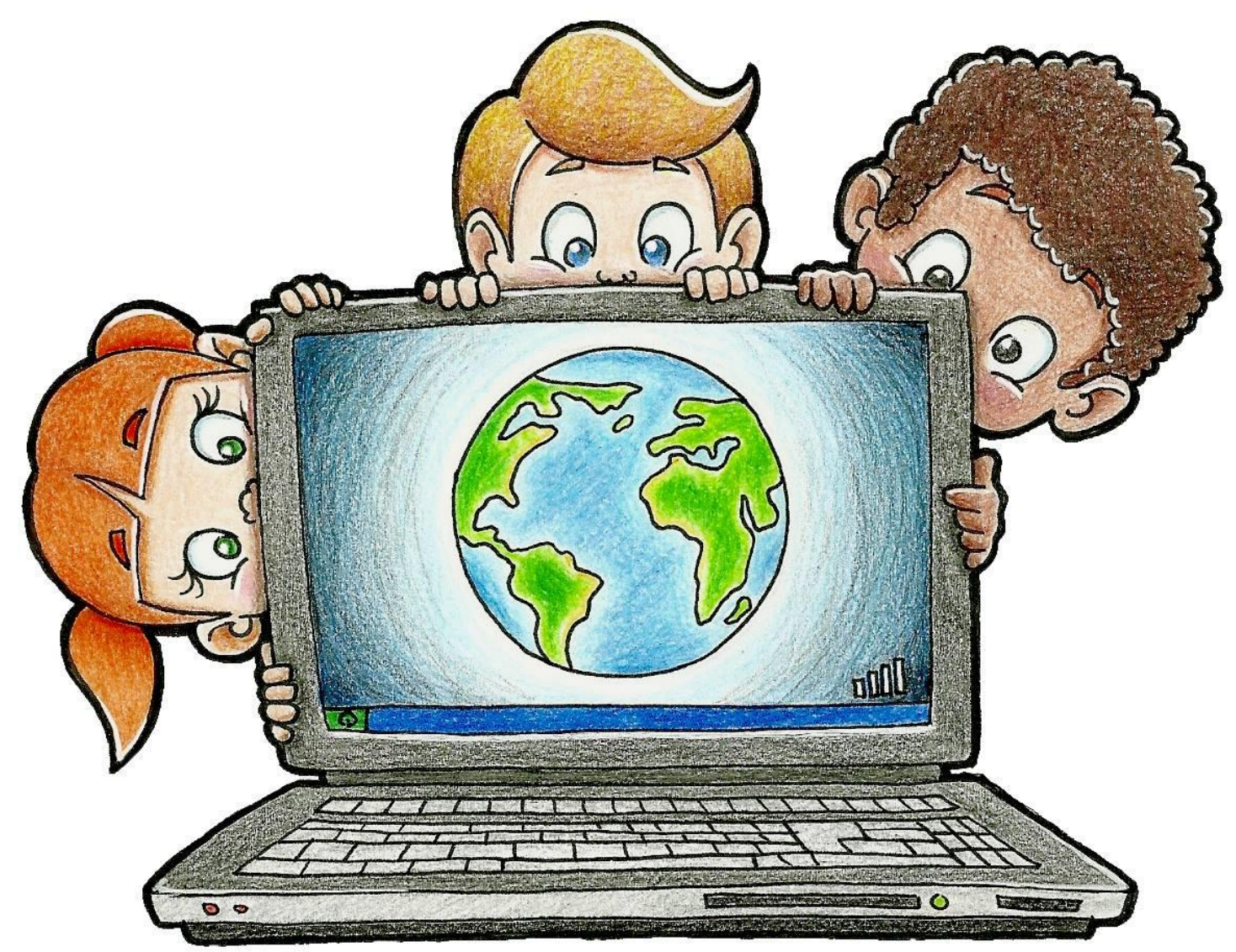

Brasília, DF

2016 


\section{SUMÁRIO}

APRESENTAÇÃO

IDENTIFICAÇÃO

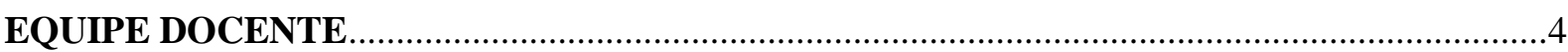

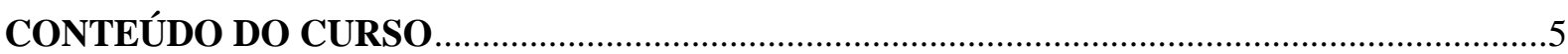

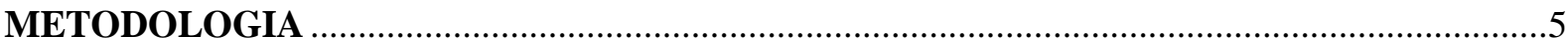

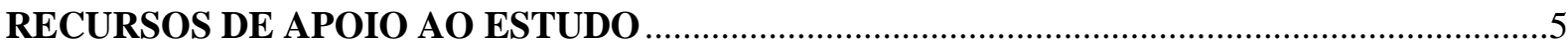

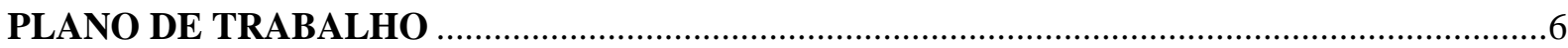

DESCRIÇÃO DAS ATIVIDADES: ENCONTROS A DISTÂNCIA …........................................

APRESENTAÇÃO - AMBIENTAÇÃO NA PLATAFORMA DE ENSINO ................................. 8

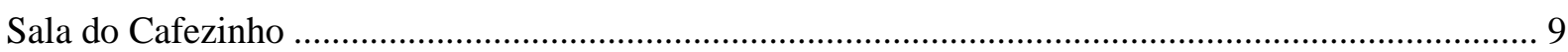

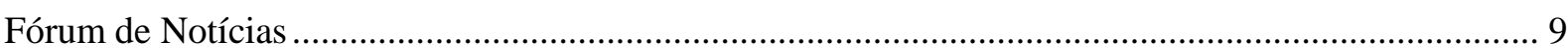

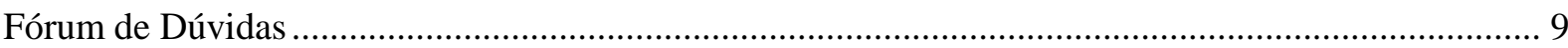

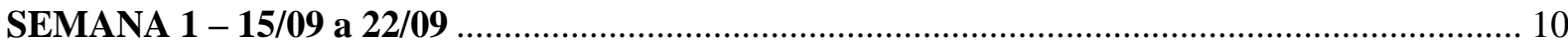

DEBATENDO SOBRE A FORMAÇÃO DO PLANETA TERRA E O SISTEMA SOLAR....... 10

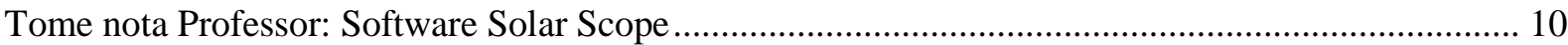

Você, o planeta Terra e o Sistema Solar - Ponto de vista Químico ........................................................ 10

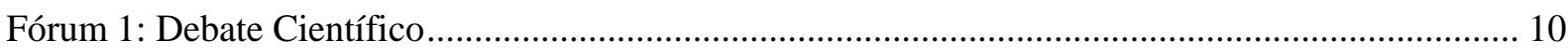

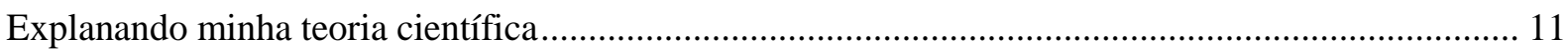

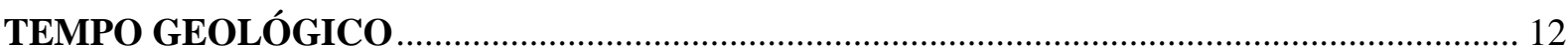

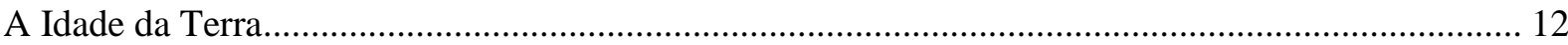

Leituras recomendadas - próxima semana $(23 / 09$ - 28/09) .................................................................... 14

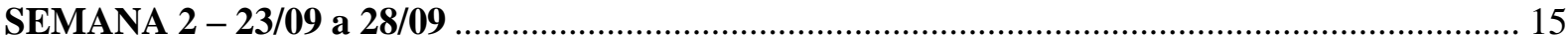

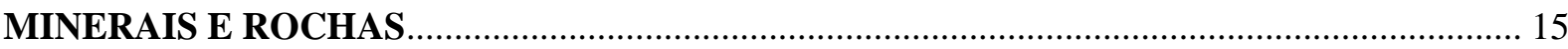

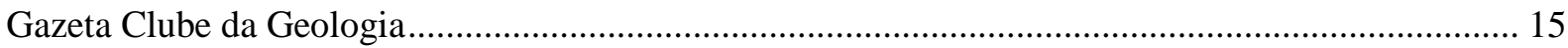

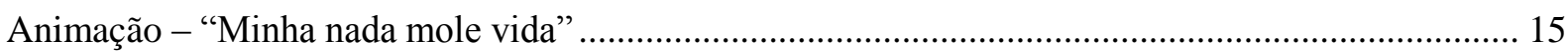

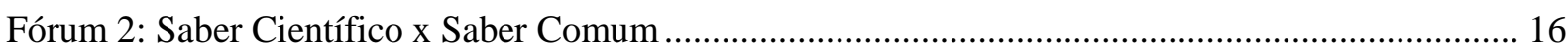

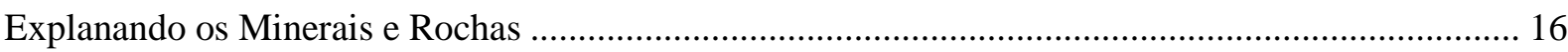

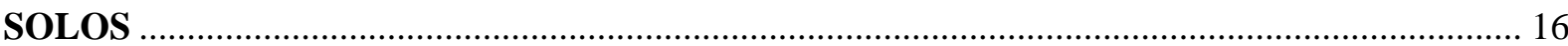

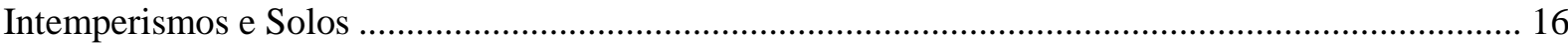

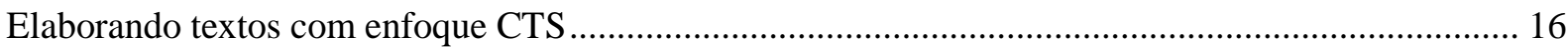

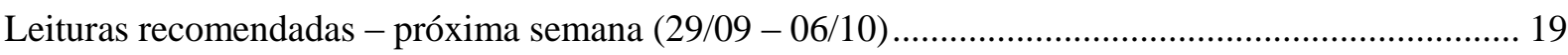

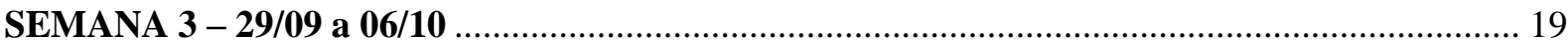

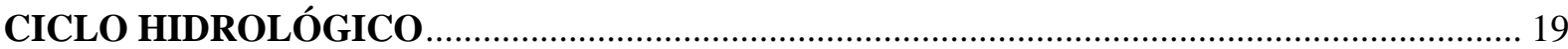




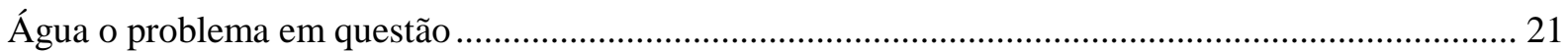

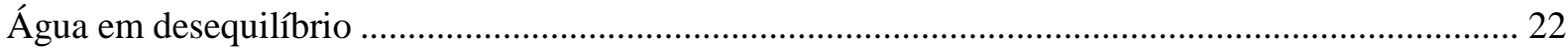

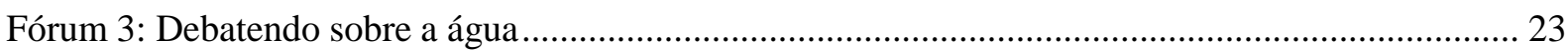

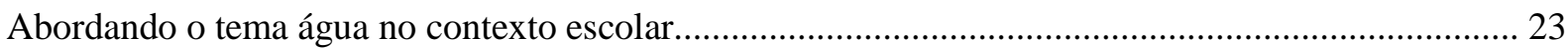

Leituras recomendadas - próxima semana $(07 / 10$ - 15/10) ….......................................................... 24

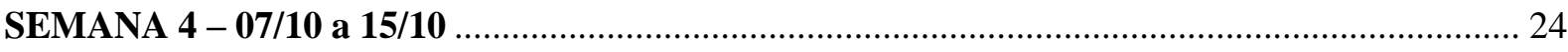

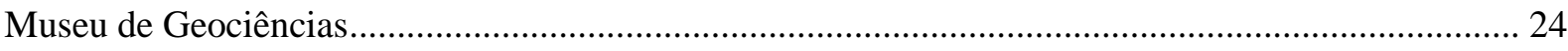

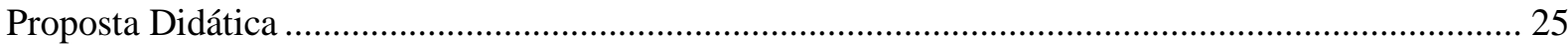

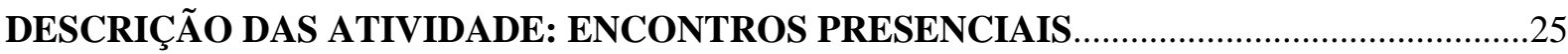

Encontro 1 (25/09) - Experimentando: Permeabilidade dos Solos/Erosão e Deslizamentos ......... 25

Encontro 2 (09/10) - Modelando o Perfil Tectônico Terrestre ........................................................... 28

Encontro 3 (15/10) - Visita orientada ao Museu de Geociências da UnB .........................................30

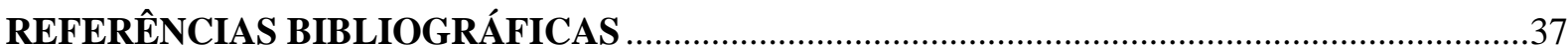




\section{APRESENTAÇÃO}

Caríssimos,

A presente ação pedagógica foi escrita e aplicada como proposta resultante da Dissertação realizada sob orientação da Prof. ${ }^{a}$ Alice Melo Ribeiro e coorientação da Prof. ${ }^{a}$ Anete Maria de Oliveira e apresentada à banca examinadora como requisito parcial à obtenção do Título de Mestre em Ensino de Ciências pelo Programa de Pós-Graduação em Ensino de Ciências da Universidade de Brasília.

O Curso intitulado "Educação em Geologia" teve como objetivo principal a formação continuada de professores que atuam no Ensino Fundamental da educação básica, na disciplina de Ciências Naturais. Essa formação buscou promover o aprofundamento dos conteúdos de Geologia atrelando teoria à prática pedagógica; compreender os temas que permitem o favorecimento do caráter sistêmico, integrado e complexo dos fenômenos terrestres; desenvolver uma consciência ambiental planetária, bem como um entendimento profícuo das questões ambientais mais pertinentes; promover a construção de recursos didáticos que favoreçam o processo de ensino e aprendizagem no ensino de Geologia e; identificar possíveis estratégias metodológicas de ensino passíveis de serem utilizadas nas aulas de Ciências Naturais, além de favorecer uma ressignificação na prática pedagógica do professor.

Sua execução se justifica pelo fato da Geologia ser uma área de estudo que não se apresenta no currículo enquanto disciplina. Suas temáticas encontram-se distribuídas nas diversas disciplinas das ciências exatas e humanas, que integram objetos de estudo durante a educação básica. Entretanto, o que se percebe é uma abordagem desarticulada e apresentada em uma estrutura fragmentada que ainda necessita de ações que possam contribuir na resolução de lacunas presentes no ensino da Geologia (TOLEDO, 2005).

Este trabalho ancora-se nos ideais de Pimenta (2005) e Nóvoa (2009), ambos salientam que um curso de formação continuada deve sempre levar em consideração os anseios dos participantes, respondendo às suas reais necessidades, além de contribuir prontamente para a ressignificação da identidade do professor. Desse modo, pretendemos assim, fornecer uma complementação na formação dos professores, sendo articulado pela parceria entre universidade e escola. 


\title{
IDENTIFICAÇÃO
}

\author{
Nome do curso: Educação em Geologia \\ Departamento Responsável: Instituto de Biologia/IB \\ Carga Horária: 60 horas \\ Duração: 4 semanas
}

\section{Professora/ministrante $\rightarrow$}

Samara dos Anjos da Costa

\section{Professora/coordenadora $\rightarrow$}

Alice Melo Ribeiro

\section{Professora/coordenadora}

Anete Maria de Oliveira

\section{EQUIPE DOCENTE}

Graduada em Ciências Naturais pela Universidade de Brasília (2013). Discente do Mestrado Profissional em Ensino de Ciências (PPGEC) pela mesma instituição. Possui experiência na área de educação, com ênfase na área de Ensino de Ciências e Ensino de Geociências, atuando em linhas de pesquisa direcionadas ao Ensino-aprendizagem e Formação de Professores. Possui experiência também com a modalidade de Educação a Distância (EaD), na qual atualmente é tutora no curso de Licenciatura em Biologia da UnB.

Link currículo lattes: http://lattes.cnpq.br/9961910487617538

Professora Adjunta da Universidade de Brasília, Instituto de Ciências Biológicas (IB), atua no Núcleo de Educação Científica para o Ensino de Biologia (NECBio) e na Universidade Aberta do Brasil (UAB). Possui graduação em Biologia pela Universidade de Brasília (2000), mestrado em Patologia Molecular (Genética Molecular / Farmacologia) pela Universidade de Brasília (2003), doutorado em Patologia Molecular (Imunologia Aplicada) pela Universidade de Brasília (2008) e pós-doutora pela Faculdade de Medicina de Ribeirão Preto (USP). Pesquisadora em Ciências da Saúde. Tem experiência na área de Farmacologia, Imunologia, Ensino Básico, Superior de Ciências Biológicas e Ciências da Saúde, e em Formação de Professores para o ensino de Ciências Naturais e Biologia. Especialista em Educação a distância (2011).

Link currículo lattes: http://lattes.cnpq.br/9457183337692067

Professora Assistente II do Curso de Licenciatura em Ciências Naturais da Faculdade de Planaltina da Universidade de Brasília (UnB). Geóloga pela UnB (1989), Mestre em Geologia Econômica pela UnB e Universidade de Pretória, África do Sul (1992). Especialização em Arteterapia pela Universidade Potiguar e Alquimy Art de São Paulo (2003). Doutoranda do Curso de Geociências Aplicadas do Instituto de Geociências da UnB/Universidade do Arizona, EUA. Professora e pesquisadora de Ensino de Geociências.

Link currículo lattes: http://lattes.cnpq.br/9125838817201409 


\section{CONTEÚDO DO CURSO}

O curso traz uma explanação dos conteúdos de Geologia, atrelados a construção de estratégias de ensino e recursos didáticos que sirvam como suporte na prática educativa dos professores e que apresentem relevância para o escopo científico. Tais como 1. Formação do planeta Terra e Sistema Solar; 2. Tempo Geológico; 3 - Minerais e Rochas; 4 - Solos; 5 Tectônica de Placas; 6 - Ciclo Hidrológico, definidos mediante pesquisa inicial com os participantes.

\section{METODOLOGIA}

O presente curso com início no dia 15 de setembro de 2015 e término no dia 15 de outubro de 2015, teve duração de 60 horas, distribuídas em encontros virtuais e presenciais, sendo $48 \mathrm{~h}$ on line (12h por semana) voltadas para o desenvolvimento dos trabalhos, leituras, participação nos fóruns e realização das atividades propostas e $12 \mathrm{~h}$ presenciais organizadas em três encontros (4 horas cada encontro). A estruturação do curso seguiu a seguinte organização:

a) Encontros a distância via Ambiente Virtual de Aprendizagem (AVA) - Moodle (70\%).

Este consiste em um software livre, executado num ambiente virtual de aprendizagem, empregado principalmente na Educação a Distância $(\mathrm{EaD})$ para acesso e navegação de participantes e disponibilização de conteúdo.

b) Encontros Presenciais (30\%): Consistiu em aulas experimentais e de campo, visando favorecer a articulação presente entre todos os processos constitutivos da Geologia, visto que esta é uma disciplina que exige agregação entre a prática e teoria.

Por se tratar de uma proposta ofertada na modalidade a distância, o presente curso levou em consideração o amplo envolvimento dos participantes nas atividades propostas em todas as semanas de estudo no AVA e nos encontros presenciais.

\section{RECURSOS DE APOIO AO ESTUDO}

Os estudos foram realizados a partir da leitura da bibliografia básica proposta, dos demais materiais didáticos disponibilizados no Ambiente de Aprendizagem Virtual da plataforma Moodle. Entre esses constaram links para sites e portais relacionados ao ensino de Geologia, bem como links para textos complementares. Na plataforma Moodle foi ainda utilizada a ferramenta denominada Fórum, promovendo a troca de ideias sobre determinado tema, bem como o esclarecimento de dúvidas diretamente com a ministrante do curso. 


\section{AVALIAÇÃO DA APRENDIZAGEM}

A avaliação foi contínua ao longo de todo o curso, compreendendo a realização de atividades relacionadas aos temas abordados e a participação nos encontros presenciais. Em todas as participações foram considerados a coerência com o tema proposto, a clareza e correção da linguagem na abordagem dos temas e a pontualidade na entrega dos trabalhos propostos. A certificação foi entregue pela própria ministrante, e emitida pelo Decanato de Extensão da Universidade de Brasília para os cursistas que cumpriram, no mínimo, $75 \%$ da carga horária prevista no curso, com mínimo de 50\% de presença nos encontros presenciais. As notas obtidas em cada um dos itens de avaliação resultaram na nota final de acordo com os pesos indicados no quadro abaixo:

\begin{tabular}{cc}
\hline Instrumentos de Avaliação & Pontuação \\
Sala do cafezinho & 3 \\
Glossário & 10 \\
\hline Fórum 1: Debate Científico & 3 \\
\hline Fórum 2: Saber Científico x Saber comum & 3 \\
\hline Fórum 3: Debatendo sobre a água & 3 \\
\hline Tarefa: Explanando minha teoria científica & 8 \\
\hline Tarefa: A idade da Terra & 8 \\
\hline Tarefa: Explanando Minerais e Rochas & 8 \\
Tarefa: Elaborando textos com enfoque CTS & 8 \\
Tarefa: Abordando o Tema água no contexto & 8 \\
\hline escolar & 10 \\
\hline Encontro presencial 1 & 10 \\
\hline Encontro presencial 2 & 10 \\
\hline Encontro presencial 3 & 8 \\
\hline Atividade final: Proposta didática & $\mathbf{1 0 0}$ \\
\hline
\end{tabular}


Seguindo-se o padrão utilizado pela Universidade de Brasília, a nota final dos participantes foi convertida em Menções, de acordo com o quadro mostrado a seguir. Foram considerados aptos a receber o certificado os participantes que obtiveram menção igual ou superior a MM (média).

\begin{tabular}{cc} 
Nota & Menção \\
\hline 9,0 a 10,0 & SS - Superior \\
7,0 a 8,9 & MS - Média Superior \\
5,0 a 6,9 & MM - Média \\
3,0 a 4,9 & MI - Média Inferior \\
0,1 a 2,9 & II - Inferior \\
0,0 & SR - Sem rendimento \\
\hline
\end{tabular}

\section{PLANO DE TRABALHO}

\begin{tabular}{|c|c|c|}
\hline PERÍODO & ATIVIDADES & TEMA \\
\hline $\begin{array}{c}1^{\mathrm{a}} \text { semana } \\
\text { Encontro virtual } \\
15 / 09 \text { a } 22 / 09\end{array}$ & $\begin{array}{c}\text { Encontro Virtual } 1 \text { - } \\
\text { Ambientação na plataforma. } \\
\text { Cumprimento das atividades } \\
\text { propostas. }\end{array}$ & $\begin{array}{c}\text { Formação do planeta Terra e Sistema } \\
\text { Solar; Tempo Geológico. }\end{array}$ \\
\hline $\begin{array}{c}2^{\text {a }} \text { semana } \\
\text { Encontro Virtual e Presencial } \\
23 / 09 \text { a } 28 / 09\end{array}$ & $\begin{array}{c}\text { Encontro Virtual } 2 \text { - } \\
\text { Realização das leituras } \\
\text { recomendadas e cumprimento } \\
\text { das atividades propostas. } \\
\text { Encontro Presencial } 1 \text { (25/09) } \\
\text { - Ação educativa: } \\
\text { experimentação. }\end{array}$ & Minerais e Rochas; Solos. \\
\hline $\begin{array}{c}3^{\mathrm{a}} \text { semana } \\
\text { Encontro virtual e Presencial } \\
29 / 09 \text { a } 06 / 10\end{array}$ & $\begin{array}{c}\text { Encontro Virtual } 3 \text { - } \\
\text { Participação e discussão das } \\
\text { atividades da semana no fórum. } \\
\text { Elaboração de } \\
\text { recursos/estratégias didáticas. } \\
\text { Encontro Presencial } 2 \text { (09/10) } \\
\text { - Ação educativa: } \\
\text { Atividades Lúdico-Práticas/ } \\
\text { Modelagem }\end{array}$ & $\begin{array}{c}\text { Tectônica de Placas - Relevo; Ciclo } \\
\text { Hidrológico. }\end{array}$ \\
\hline $\begin{array}{c}4^{\mathrm{a}} \text { Semana } \\
\text { Encontro Presencial } \\
07 / 10 \text { a } 15 / 10\end{array}$ & $\begin{array}{l}\text { Encontro Presencial } 3 \text { (15/10) } \\
\text { - Visita espaço não formal de } \\
\text { ensino (Proposta) Fechamento } \\
\text { curso. } \\
\text { Ação educativa: } \\
\text { Saída de campo } \\
\text { Museu de Geociências UnB }\end{array}$ & Didática/Geologia \\
\hline
\end{tabular}




\section{APRESENTAÇÃO - AMBIENTAÇÃO NA PLATAFORMA DE ENSINO}

Sala do Cafezinho: Nesse primeiro contato e início de curso, os participantes deverão apresentar-se aos demais colegas, informando sua área de formação, tempo que leciona, em quais anos e séries estes estão atuando, as pretensões com relação ao que a ação poderá agregar na prática pedágogica, expectativas, dúvidas, experiências e questões que possuam um envolvimento direto com o tema.

\section{Prezad@s, cursistas! 9}

Sejam todos bem-vindos!

Este é um espaço reservado para apresentação, você deverá informar sua área de formação, tempo que leciona, séries e turmas que estão atuando, as pretensões com relação ao que o curso poderá agregar na prática pedagógica, expectativas, dúvidas e experiências.

Além disso, o objetivo aqui é o de humanizar o espaço virtual, estabelecer vínculos com seus colegas de curso e descobrir afinidades.

Ao longo do curso você poderá deixar recados aos colegas, poesias, fotos, receita de bolo, texto ou o que achar importante compartilhar, materiais do ensino de ciências ou de educação.

Aproveitem bastante!

"Sem a curiosidade que me move, que me inquieta, que me insere na busca, não aprendo, nem ensino." 


\section{Fórum de Notícias:}

Olá, cursistas! Bem vind@s ao curso Educação em Geologia!

Este espaço é destinado para partilharmos notícias a respeito do curso, tais como dia e horários dos encontros presenciais, novidades e objetos de estudo inerentes a Geologia. Durante as próximas semanas $(16 / 09$ a 15/10) eu serei a Professora/Ministrante Responsável pelo curso. Quaisquer problemas entrem em contato.

\section{Abraços virtuais!}

Desejo um bom curso para todos. (

Samara dos Anjos

\section{Fórum de Dúvidas:}

Caros cursistas,

Para que as tarefas propostas ao longo do curso possam ser bem executadas, vocês contarão com este espaço para auxiliá-los. O mesmo é destinado para o provimento de orientações acerca das atividades. Logo, em caso de dúvidas, não deixem de entrar em contato.

Saudações

Samara dos Anjos

\section{Terminologias Geocientíficas (Glossário):}

Prezad@s, cursistas!

Vamos construir um glossário a partir de cada atividade executada ao longo do nosso curso?

Assim como em toda ciência, as terminologias científicas estão presentes e servem para denominar as coisas em cada campo do conhecimento. Após cada viagem realizada no mundo da Geologia, liste os termos do qual você conseguiu construir um conceito ou de termos que conhece. O intuito dessa atividade é que ao final do curso possamos criar nosso próprio glossário geológico, de maneira que facilite a abordagem dos temas junto aos nossos alunos.

Cada participante deverá acrescentar ao glossário no mínimo dois termos.

Bom trabalho! 
SEMANA 1 - 15/09 a 22/09

Debatendo sobre a formação do Planeta Terra e o Sistema Solar

"Dust in the wind, all we are is dust in the wind."

"Poeira no vento, tudo o que somos é poeira no vento."

Kansas

Ponto de partida

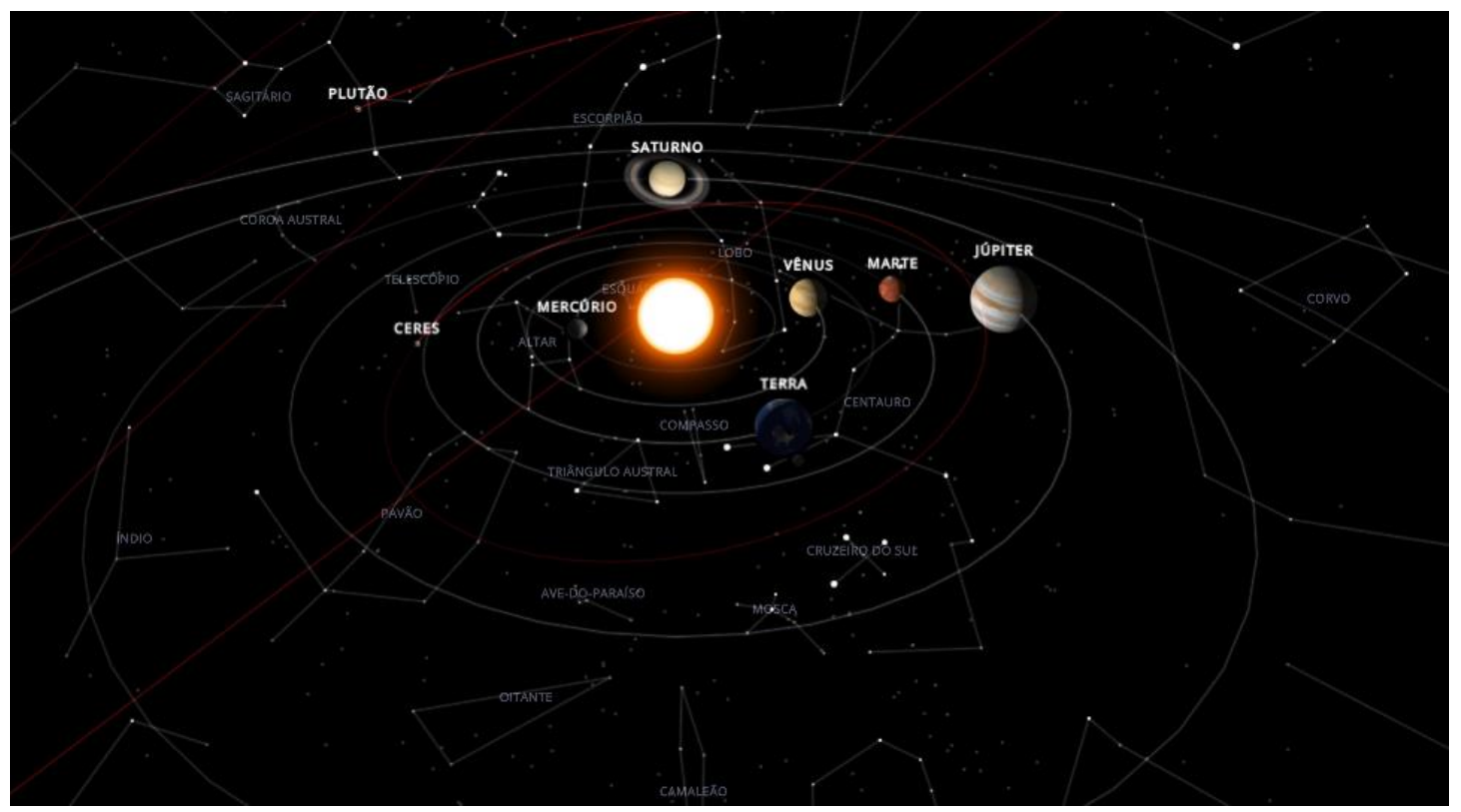

Fonte: Solar System Scope

Tome nota Professor - Software Solar Scope: O Solar System Scope é um simulador 3D e interativo do Sistema Solar. Nele é possível visualizar o Sol e os planetas, bem como ter acesso às suas características.

\section{Você, o planeta Terra e o Sistema Solar - Ponto de vista Químico:}

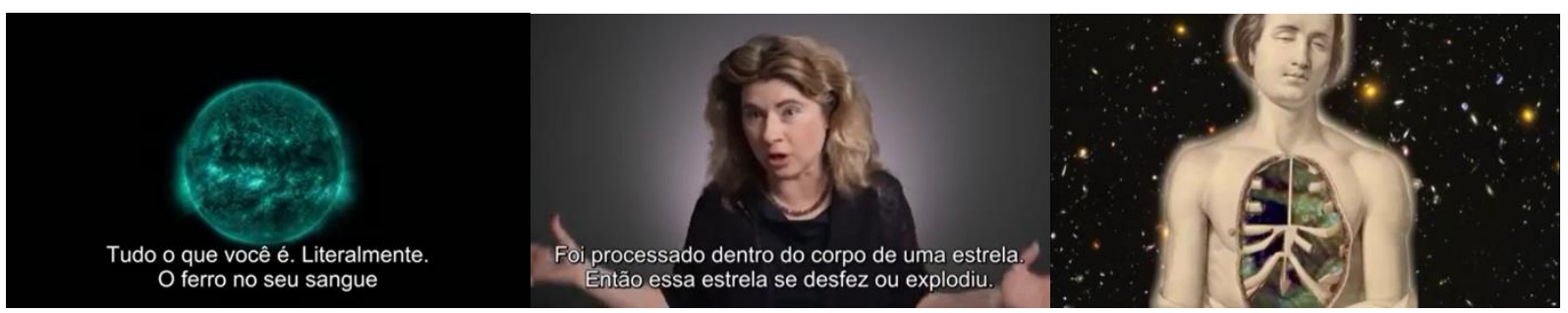

Link de acesso: $h t t p s: / / w w w . y o u t u b e . c o m / w a t c h ? v=M w U G 93 e G j N 4$

Fórum 1: Debate Científico

Prezad@s cursist@s! 
Após o manuseio do software "Solar System Scope" e ao assistir o vídeo "Supernovas - Somos Estrelas Mortas" vamos buscar compreender como ao longo do tempo as pessoas procuraram respostas acerca dos mistérios do Sistema Solar e origem da vida na Terra.

A perspectiva histórica ocupa um amplo papel na área do ensino de ciências e demais áreas. Sua inserção permite aos professores e educandos compreender como se deu o processo gradativo e lento da construção do conhecimento científico ao longo de sucessivos acontecimentos históricos, filosóficos e sociais. De acordo com Carneiro e Gastal (2005), a inclusão da história e filosofia das ciências nos diversos currículos do Ensino Fundamental e/ou Ensino Médio, podem propiciar tanto para alunos como para professores uma maior compreensão da natureza do conhecimento científico, suas teorias e leis, e, por conseguinte uma concepção das ciências com um empreendimento coletivo que possui amplas relações com a tecnologia, cultura e sociedade.

Tomando como base a importância da história para compreensão dos fatos da ciência e suas descobertas, chegou a hora de abrirmos nosso "Debate Científico" respondendo as seguintes questões:

1. Quais são, atualmente, as teorias existentes que buscam explicar a origem do Sistema Solar e da vida? Faça uma breve explanação sobre cada uma delas, enfatizando o ano de surgimento e o seu percussor.

2. Faça um comentário na resposta do colega, atribuindo suas concepções acerca da teoria explanada.

Bons estudos!

\section{Explanando minha teoria científica}

Prezad@s, cursist@s!

A - Após a pesquisa realizada no fórum 1: Debate Científico, cada participante deverá escolher uma teoria e buscar teses que a sustentem, enaltecendo as observações e experimentos que levaram a formulação de hipóteses, evidências, bem como os fatos principais que a tornaram uma teoria. O objetivo é argumentar seus pontos principais, como se esta ainda tivesse que trilhar em busca de uma aceitação pela "comunidade científica".

Este será um momento propício para dicurtir acerca das curiosidades e fenômenos que integram a história da Terra e dos seus constituintes, além de buscar artificios para a construção de uma visão interdisciplinar, moldada pelo conhecimento científico pertencente ao campo de estudo da Geologia, Química, Física, Biologia, Filosofia,

História, Geografia e Paleontologia. 
B - Quando se fala no planeta Terra, você prontamente começa a imaginar e a se perguntar:

Como surgiu a vida na Terra? Como ocorreu a sua diversificação? As condições climáticas existentes no planeta primitivo são as mesmas encontradas hoje? Quais evidências explicam o surgimento da vida multicelular?

A busca pelas respostas das questões apontadas acima necessita de uma gama de conhecimentos unificados a diferentes áreas para o levantamento de hipóteses ou até mesmo de explicações, conhecimentos estes coletados no presente e no passado, e apresentados sob a forma de evidências. Nesse campo repleto de dúvidas e incertezas é que a Geologia, mais precisamente o seu presente geológico se apresenta como a chave para desvendar os grandes enigmas da história da Terra.

Munido dos conhecimentos inerentes à formação do planeta Terra e do surgimento dos seres vivos, os participantes deverão responder as questões lançadas acima, com base na teoria pesquisada, fundamentando e justificando a sua importância para explicitação dos fatos e fenômenos.

Bom trabalho!

\section{Tempo Geológico}

\section{A Idade da Terra}

"Por seres tão inventivo e pareceres contínuo, tempo, tempo, tempo, és um dos deuses mais lindos, tempo, tempo, tempo, tempo...".

Caetano Veloso

O que é o tempo? É fácil quantificá-lo? Uma criança e um adulto podem ter diferentes concepções de tempo; por exemplo, qual foi a época da ditadura militar brasileira: aconteceu há muitos anos ou faz parte de um passado recente? Um adulto que talvez tenha vivenciado este período provavelmente o classificaria como algo razoavelmente recente. Já a criança certamente diria que a ditadura é do tempo dos avós. Mas o que será que ambos pensam sobre a época do surgimento do planeta Terra? Será que os continentes sempre estiveram organizados da maneira como conhecemos? Se não, quando estes assumiram a sua configuração atual? Gould (1991) nos diz que o tempo geológico, também definido como tempo profundo, é muito estranho às nossas formas de percepção. A duração dos períodos de tempo torna-se cada vez mais abstrata, à medida que se afasta daquela passível de ser percebida ao longo da existência de uma pessoa, pois se torna um tanto vago 
raciocinar com espaços de tempo de milhões de anos, quando temos a noção de, no máximo, dezenas de anos. A Terra é um "planeta vivo": tanto os seres vivos quanto o ambiente estão em constante mudança. Este entendimento é fundamental para o estudo do tempo geológico e da evolução biológica. Torna-se bastante coerente pensar que, ao longo dos bilhões de anos da história do nosso planeta, surgiu uma grande diversidade de organismos - alguns já extintos, outros que permanecem até hoje -; as inúmeras formas de vida só podem ser explicadas pelas mudanças nos diferentes tipos de ambientes.

Agora vamos imaginar que o tempo decorrido desde a formação da Terra até hoje, ou seja, seus 4,6 bilhões de anos de história fossem comprimidos em um ano. Em um calendário - Calendário do Tempo Geológico - representando esse ano, poderíamos acompanhar o registro de importantes eventos geológicos e biológicos que ocorreram na história da Terra. Na tabela a seguir estão relacionadas as idades aproximadas de importantes eventos (em milhões de anos) que marcaram a história geológica da Terra e que poderiam estar registrados no Calendário do Tempo Geológico.

Texto: Fábio A. Rodrigues, Demetrio D. Nicolaidis, Russel Terezinha D. da Rosa

Você vai descobrir quando cada um desses eventos ocorreu no Calendário do Tempo Geológico comprimido em um ano. Para isso, alguns cálculos deverão ser feitos. A fórmula geral para calcular as datas dos eventos é:

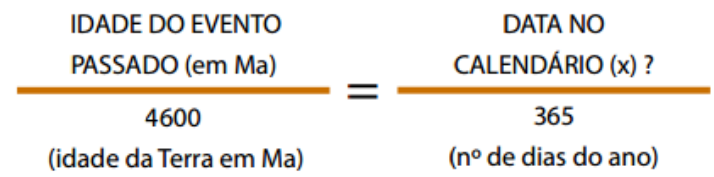

Utilizando a fórmula acima, determine a data de cada um dos eventos. Para saber o "mês e o dia" em que cada evento ocorreu, construa os meses, acrescentando os 365 dias do ano em sequência decrescente ao longo dos meses, exemplificada abaixo pelo mês de janeiro.

\begin{tabular}{|l|l|l|l|l|}
\hline \multicolumn{5}{|c|}{ JANEIRO } \\
\hline $1(365)$ & $2(364)$ & $3(363)$ & $4(362)$ & $5(361)$ \\
\hline $6(360)$ & $7(359)$ & $8(358)$ & $9(357)$ & $10(356)$ \\
\hline $11(355)$ & $12(354)$ & $13(353)$ & $14(352)$ & $15(351)$ \\
\hline $16(350)$ & $17(349)$ & $18(348)$ & $19(347)$ & $20(346)$ \\
\hline $21(345)$ & $22(344)$ & $23(343)$ & $24(342)$ & $25(341)$ \\
\hline $26(340)$ & $27(339)$ & $28(338)$ & $29(337)$ & $30(336)$ \\
\hline $31(335)$ & \multicolumn{4}{|c}{} \\
\hline
\end{tabular}




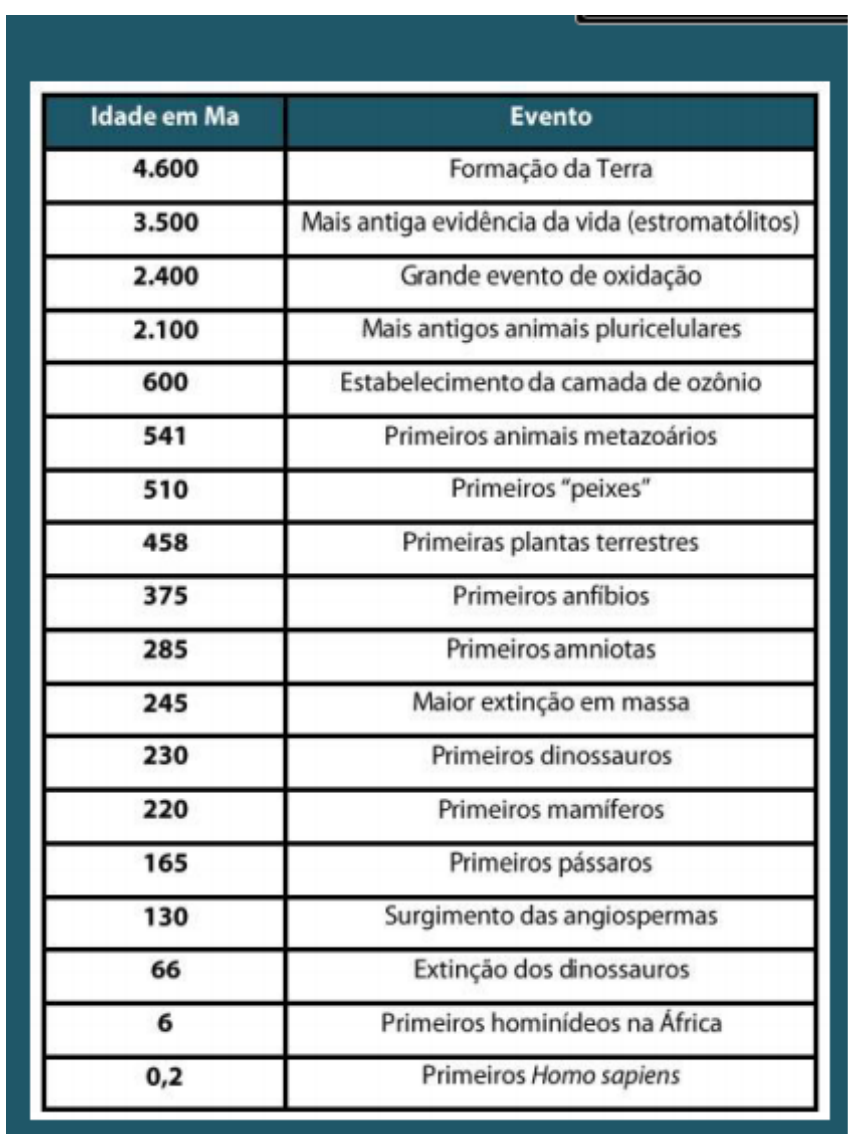

Elabore um comentário a respeito do que você concluiu com esse exercício.

Fonte: Paleontologia na sala de aula.

\section{Leituras recomendadas - próxima semana (23/09 - 28/09)}

SANTOS. W, L, P.; MORTIMER. E, F. Uma análise dos pressupostos teóricos da abordagem C-T-S (Ciência Tecnologia - Sociedade) no contexto da educação brasileira. Ensaio. Pesquisa em Educação, n. 2, v. 2, p. 1-23, 2002.

SILVA, R. R.; MACHADO, P. F. L.; TUNES, E. Experimentar Sem Medo de Errar. In: SANTOS, W. L. P.S.; MALDANER, O. A. (Org.). Ensino de Química em foco. ljuí: Editora Unijuí, p. 231-261. 2010. 
SEMANA 2 - 23/09 a 28/09

\author{
Minerais e Rochas
}

"Aprendi o segredo da vida, vendo as pedras que sonham sozinhas no mesmo lugar."

Raul Seixas

www.clubedageologia.com.br

\title{
GAZETA CLUBE DA GEOLOGIA
}

EXEMPLAR DE ASSINATE ${ }^{\circ}$ VENDA PROIBIDA

BRASILIA DISTRITO FEDERAL, QUARTA-FEIRA, 23 DE SETEMBRO DE 2015

NÚMERO $1^{\circ} 2$ PÁGINAs

\section{AS ROCHAS E $O$ \\ SEU CICLO DE VIDA}

É um agregado natural formado por dois ou mais minerais, que constitui parte da crosta terrestre. Podem ser classificadas de acordo com os seus materiais constituintes e seu ambiente de formação. Há três grupos de rochas, sendo eles ígneas, metamórficas e sedimentares.

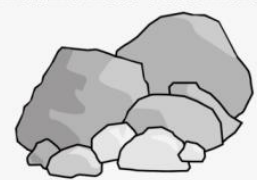

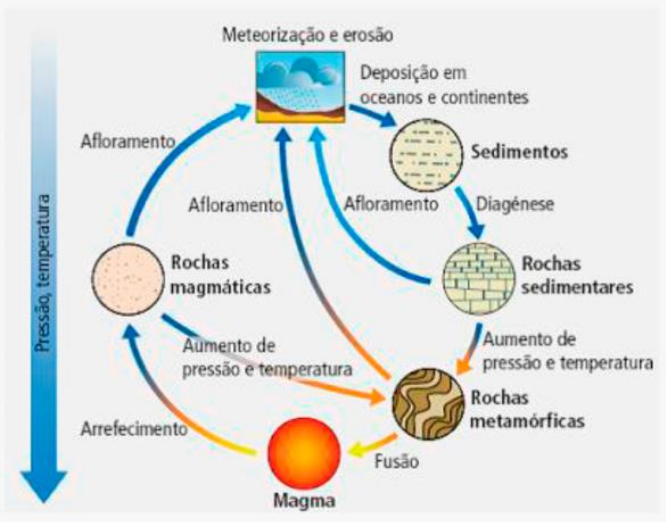

\section{COMPONENTES DAS ROCHAS}

Substância ou elemento químico de ocorrência natural, sólido, com sistema cristalino ordenado tridimensionalmente, geralmente inorgânico, com composição química definida dentro de certos limites que ocorre na Terra ou em corpos extraterrestres. Os minerais têm grande importância para a sociedade, são bastante utilizados na construção de casas e edifícios.

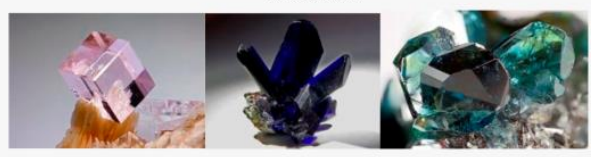

As rochas igneas são formadas pela cristalização do magma, material rochoso fundido a altas temperaturas, proveniente do interior do planeta Terra. Existem dois tipos de rochas igneas: intrusivas e extrusivas. Quando o magma se solidifica no interior da crosta, temos a formação da rocha ignea intrusiva ou plutônica. Quando a solidificação do magma, agora lava, ocorre na superficie da crosta $\mathrm{em}$ contato com a hidrosfera e atmosfera, por meio da erupção de vulcões e agora em contato com condições de pressão e temperatura diferentes do interior do planeta, temos a formação de rochas igneas extrusivas ou vulcânicas. As rochas ígneas intrusivas por estarem submetidas a altas pressões e temperaturas, exibem uma granulação grossa a média, em decorrência da cristalização demorada dos seus minerais. Já as rochas ígneas extrusivas se eristalizam rapidamente, elas exibem uma granulação muito fina, não sendo possivel visualizar seus minerais a olho nu.

\begin{abstract}
As rochas metamórficas originam-se de rochas já preexistentes por modificação nas associações mineralógicas, na textura e na estrutura. Essas modificações ocorrem quando essas rochas são submetidas a condiçõe fisicas (pressão e temperatura) diferentes daquelas onde ela se formaram. A pressão, temperatura e a atuação de fluidos, são os principais agentes de metamorfismo. Os três principais tipos de metamorfismo são: metamorfismo regional - grandes áreas são metamorfizadas por alta pressões e temperaturas geradas durante a construção de montanhas por dobramentos, e acavalamento de rocha acamadas, frequentemente acompanhada de atividade magmática. Metamorfismo de contato - rochas encaixante são metamorfizadas, pelo calor do corpo ígneo que nelas se intrude e metamorfismo hidrotermal - que é o resultado da percolação de águas quentes ao longo de fraturas e espaços das rochas, metamorfizando-as.
\end{abstract}

As rochas sedimentares originam-se do acúmulo e degradação de rochas que ficam expostas à atmosfera, que passam a sofrer assim a ação do intemperismo (mudanças químicas físicas que ocorrem nos sedimentos rochas). As rochas intemperisadas perdem a sua coesão passam a ser erodidas e transportadas por diferentes agentes (água vento, gelo e gravidade) até su

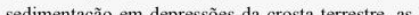
sedin inconsolidados em rochas sedimentares é causada pela compactação e cristalização de materiais que cimentam o grãos dos sedimentos.
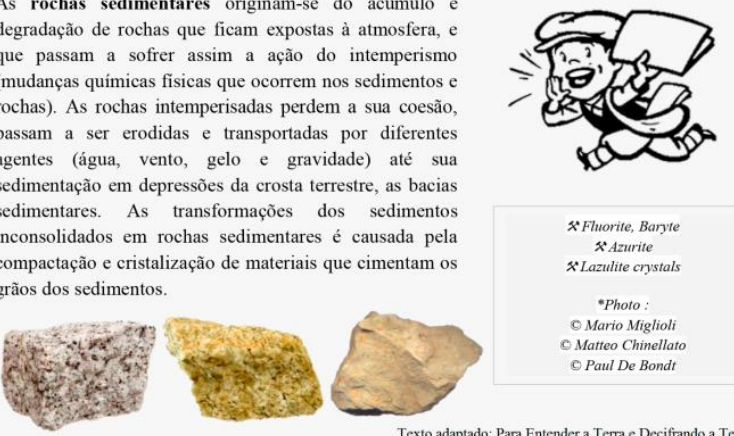

Fhorite, Baryte x Azurite $x$ Lazulite crystals "Photo: - Mario Miglioli o Paul De Bondt

\section{Animação - "Minha nada mole vida"}

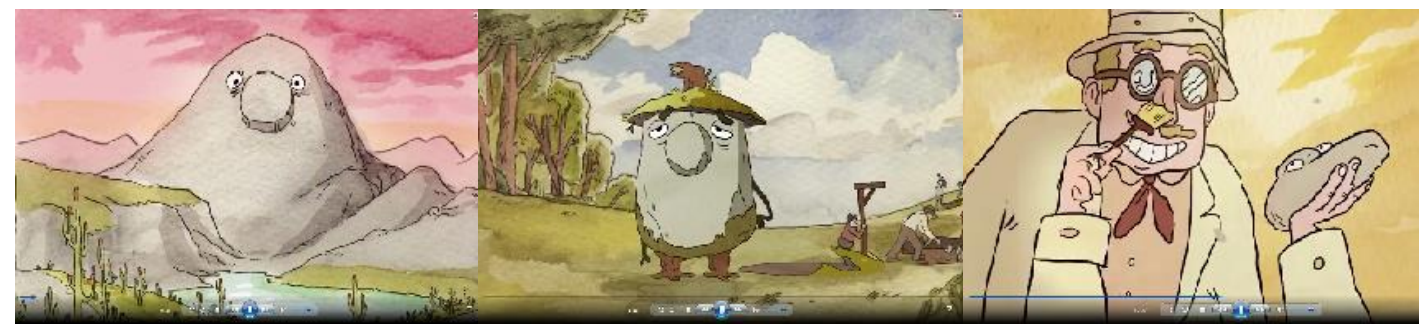

Link de acesso: https://www.youtube.com/watch?v=DsQelCsfg0o 


\section{Fórum 2: Saber Científico $\times$ Saber Comum}

Olá, cursistas!

Vamos reforçar o nosso glossário? Localize termos técnicos presente no texto do jornal informativo: Gazeta Clube da Geologia que você acredita ser de difícil compreensão e busque conceituá-los em uma linguagem mais clara. Em seguida responda as indagações presentes abaixo.

1. Como transpor os termos científicos para o saber comum, de maneira que a população tenha acesso ao conhecimento científico?

2. Qual a importância do conhecimento baseado no senso comum? Qual a sua diferença em relação ao conhecimento científico?

Lembrem-se sempre de comentar na resposta do colega, esse espaço é uma roda de conversa virtu@।, nele estamos trabalhando em prol de uma construção coletiva, com vistas ao saber.

Abs,

Samara dos Anjos

\section{Explanando os Minerais e Rochas}

Após a leitura do jornal informativo, Gazeta Clube da Geologia, vamos executar as seguintes atividades:

Como você acredita que as rochas são formadas? Elabore com bases nos seus conhecimentos e em sua área de formação uma história, vídeo ou desenho que evidencie o processo de formação das rochas, não se esqueça de indicar os possíveis locais de formação de cada tipo, além de identificar em seu cotidiano, artefatos, utensílios e objetos nos diversos setores, sejam eles industriais, tecnológicos, cosméticos, dentre outros, que não existiriam sem os minerais e rochas.

Após identificar os possíveis locais de formação de cada tipo de rocha, escolha um local no planeta Terra em que pode ser encontrado esse tipo de ambiente, e explicite algumas das características físicas, químicas, biológicas e sazonais. Por exemplo: Sistema de Rift do Leste Africano, nele há formação principalmente de rochas sedimentares. Para auxiliá-los nesta atividade, os participantes poderão ter acesso ao Google Earth. 
Link para download: https://www.google.com/earth/

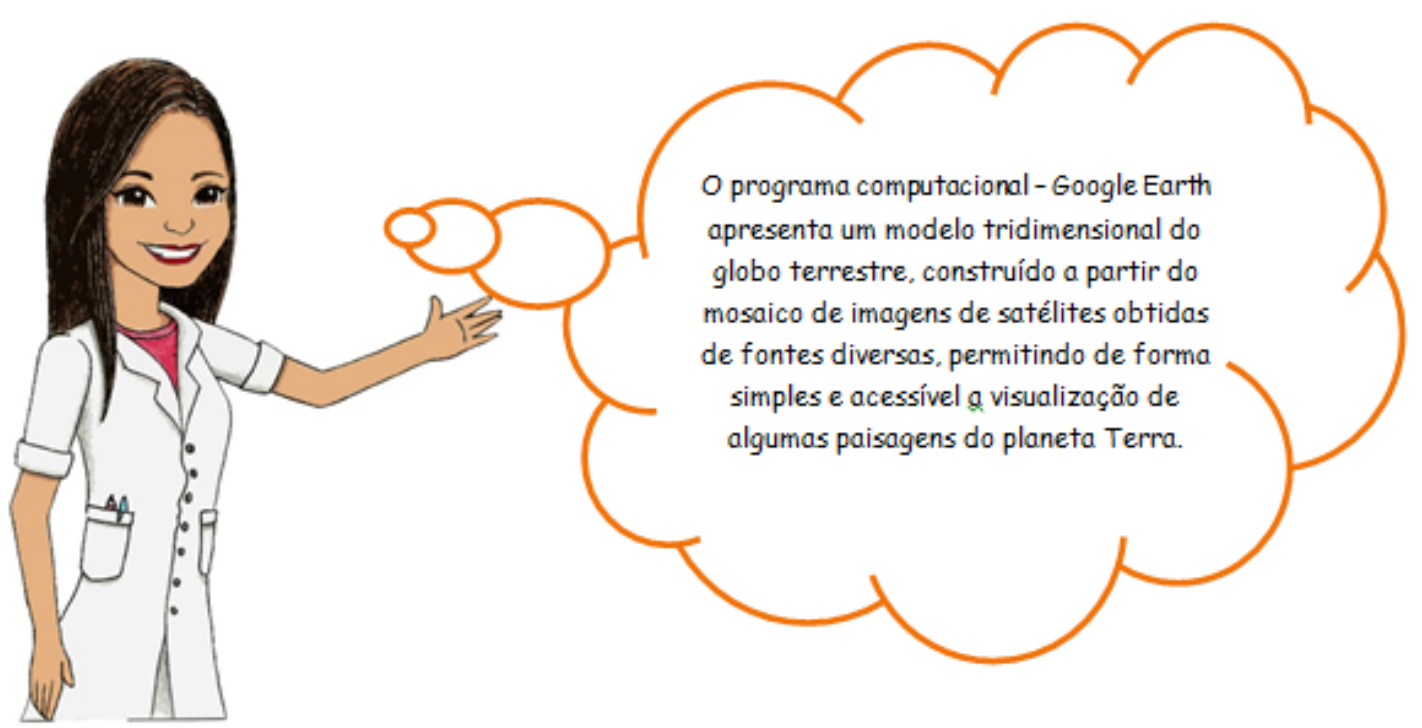

Solos

\section{Intemperismos e Solos}

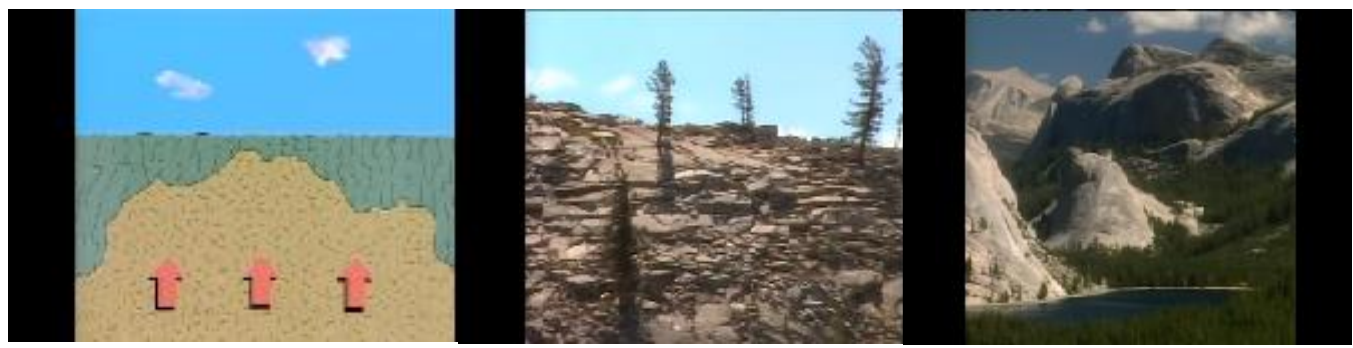

Link de acesso: $h t t p s: / / w w w . y o u t u b e . c o m / w a t c h ? v=n y l 0 z \_1 X b \circ 4$

\section{Elaborando textos com enfoque CTS}

Caros participantes,

A atividade a seguir consiste na elaboração de textos científicos com enfoque na abordagem CTS. Esta atividade se constitui como um fator determinante da aprendizagem em ciências, pois, para aprender ciências, é necessário que os educandos se apropriem de um vocabulário que favoreça a linguagem científica, de modo que seja possível relacionar os fatos com explicações científicas embasadas, 
compreendendo que determinada situação, fato histórico ou problema pode ter diversas interpretações (LAVILLE e DIONNE, 1999; SANMARTI, 1997).

Obs.: Para uma melhor execução da atividade, é importante que você cursista tenha realizado a leitura do texto: Uma análise dos pressupostos teóricos da abordagem

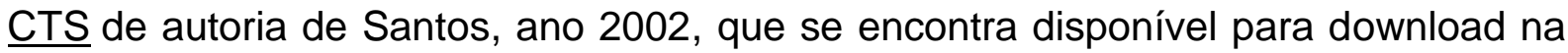
pasta de leituras recomendadas da primeira semana.

\section{Para tanto, a tarefa a seguir poderá ser realizada em duplas ou em trios e deverá seguir às seguintes etapas:}

\section{Etapa I: Escolha de uma problemática Local}

-> Apresente reportagens que elucidem alguma questão relacionada ao solo;

- Escolha uma questão, local que pode ser observada no contexto dos seus alunos, um problema emergente que envolva alguma questão ambiental. Ex: Ocupação indevida de alguma região (casas, construções e similares) desencadeando o deslizamento do solo.

\section{Etapa II: Associação}

-> Após definição da problemática, associe o problema em questão a um tema do ensino de ciências, neste caso, do ensino de Geologia.

- É possível relacionar o deslizamento do solo aos fatores que envolvem às suas características, tais como formação, permeabilidade, porosidade e tipos de solos. Bem como sua relação com os fenômenos químicos, físicos e/ou biológicos controlados pelo Sistema Terra.

\section{Etapa III: Levantamento de hipóteses}

-> Observe mediante a situação descrita, quais fatores podem ter influenciado diretamente no deslizamento do solo e estruture um texto informativo, de cunho investigativo.

- Esse levantamento é de suma importância para que o professor possa explorar o espírito investigativo nos alunos ao trabalhar o texto informativo em sala de aula.

\section{Etapa IV: Discussão e Reflexão}

-> Nesta etapa é importante realizar uma discussão e reflexão das questões que caracterizam a problemática. Quais pontos poderão ser abordados ao longo de um texto científico, de modo que os alunos possam expor suas opiniões acerca da situação apresentada?

- Esse é um momento propício para compreender, por exemplo, quais são as normas e políticas públicas bem como a distribuição e organização dos diversos tipos de solo e como ocorre a ocupação e exploração territorial. 


\section{Etapa V: Apresentação de soluções para o impasse}

-> Essa etapa pode ser um mecanismo de avaliação do texto como ferramenta nas aulas de Ciências Naturais, essas soluções deverão emergir dos próprios alunos, que após a leitura do texto elaborado pelos professores, poderão expor medidas que possam solucionar o problema em questão. Como a atividade não vai ser aplicada em um primeiro momento, você professor, deverá citar possíveis soluções para a problemática apresentada, correlacionado os mesmos processos em outras localidades do planeta.

- Realize uma comparação do problema destacado com outros casos regionais ou globais.

Excelente construção a todos!

\section{Leituras recomendadas - próxima semana (29/09 - 06/10)}

BACCI. D, de La C.; PATACA. E, M. Educação para a água. São Paulo, v. 22, n. 63, 2008.

CONSTANTE, A.; VASCONCELOS, C. Actividades lúdico-práticas no ensino da Geologia: complemento motivacional para a aprendizagem. Terra e Didatica, Porto, v. 2, n. 6, p.101-123, 2010. Faculdades Integradas de Jacarepaguá, 2009.

\section{SEMANA 3 - 29/09 a 06/10}

\section{Ciclo Hidrológico}

"Ô chuva vem me dizer, se posso ir lá em cima pra derramar você."

Marisa Monte

Ponto de partida $\Theta$

Os fenômenos dos quais a água participa, como intemperismo, erosão, assoreamento, circulação do ar, clima, dissolução de substâncias, são fundamentais para a organização da superfície terrestre em todas as suas esferas, sendo elas a litosfera, biosfera, hidrosfera e atmosfera. A compreensão desses domínios, bem como as inter-relações entre eles, ajuda a construir a ideia da dinâmica da Terra.

Recurso natural indispensável para a manutenção da vida, a água tornou-se a preocupação iminente das últimas décadas, São Paulo, estado localizado na região sudeste do país, tem vivenciado atualmente umas das priores crises com a falta de água. 


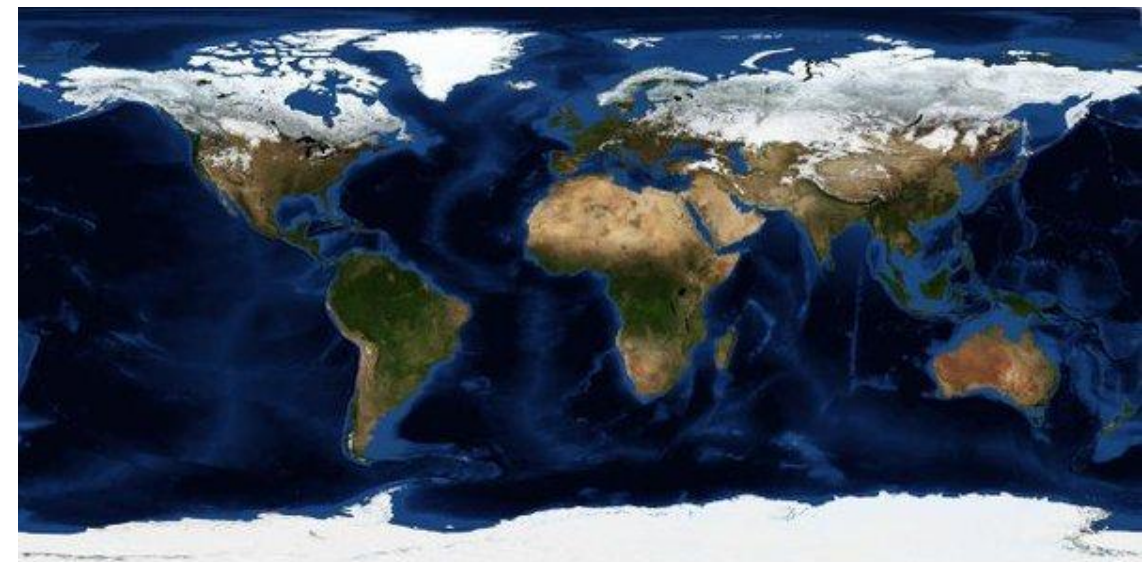

Fonte imagem: Blog Ciências

Neste contexto a interação entre ciência, tecnologia e sociedade propiciará o desenvolvimento de valores e ideias por meio de estudos de temas locais, políticas públicas e temas globais, atentando os educandos quantos às problemáticas que emergem cotidianamente em nossa sociedade.

A utilização de atividades com ênfase em CTS (Ciência-Tecnologia-Sociedade) no contexto da educação brasileira visa beneficiar o ensino e aprendizagem do educando, uma vez que se busca preparar o aluno para o exercício da cidadania consciente, com foco para reflexões, capacitandoos a analisar problemáticas ambientais indo ao encontro de possíveis soluções (SANTOS e MORTIMER, 2002).

Leia atentamente os seguintes noticiários:

Links das reportagens:

http://maxmillianomelo.blogspot.com.br/p/reportagens.html

\begin{tabular}{|c|c|c|c|c|}
\hline $\begin{array}{l}\text { IVEST } \\
\text { o fim } \\
\text { ra } \\
\text { a vida } \\
\text { a } *\end{array}$ & & 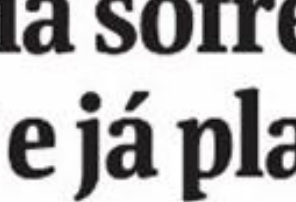 & 10 & \\
\hline $\begin{array}{l}\text { spital } \\
0 \text { de } \\
\text { em } \\
\text { bres } c\end{array}$ & $\begin{array}{l}\text { Em pesquisa Datafolha } \\
\text { feita na ültima sexta (17), } \\
60 \% \text { dos paulistanos dizem } \\
\text { ter ficado sem água em al. } \\
\text { gum momento nos úttimos } \\
30 \text { dias. Com medo mo desa- } \\
\text { bastecimento, } 66 \% \text { afirmam } \\
\text { que planejam estocar água. }\end{array}$ & $\begin{array}{l}\text { A Giltima interrupxầo du- } \\
\text { rou mais de seis hooras, se- } \\
\text { gundo três em cada quatro } \\
\text { atingidos. Entre os que mo- } \\
\text { ram em casa, } 67 \% \text { tiveramo } \\
\text { problema no periodo. Entre } \\
\text { os que vivememapartamen- } \\
\text { tos, o indice é de } 26 \% \text {. }\end{array}$ & $\begin{array}{l}\text { s atingiram } 60 \% \\
\text { o corte afeta } 65 \% \text { da po- } \\
\text { pulaçao mais pobre e } 32 \% \\
\text { entre os que têm renda aci- } \\
\text { ma de dez salários, A maio- } \\
\text { ria entre os mais pobres, } \\
82 \% \text {, diz estar reutilizando } \\
\text { akgua. Entre os mais ricos. } \\
76 \% \text { n.jo lavam mais ocarro. }\end{array}$ & 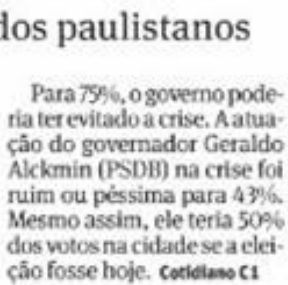 \\
\hline
\end{tabular}

\begin{tabular}{|c|c|}
\hline $\begin{array}{l}\text { Na Utima ver que } \\
\text { taltod água em wa } \\
\text { casa, o problema } \\
\text { durou menos de seis } \\
\text { hoces ou mats de } \\
\text { seis horas? }\end{array}$ & $\begin{array}{l}\text { Mais de } \\
\text { seis hores }\end{array}$ \\
\hline
\end{tabular}

de begua pora

ieterrompida
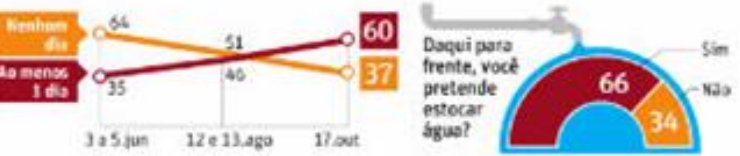


\section{Água o problema em questão}

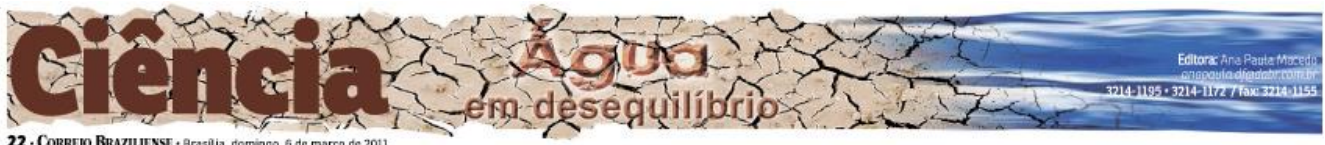

\section{A crise já começou}

Aquecimento global, expansão urbana descontrolada e falta de investimentos em saneamento fazem com que 0 acesso à água potável esteja cada vez mais difícil em muitas regiões do planeta. Especialistas preveem agravamento constante da situação
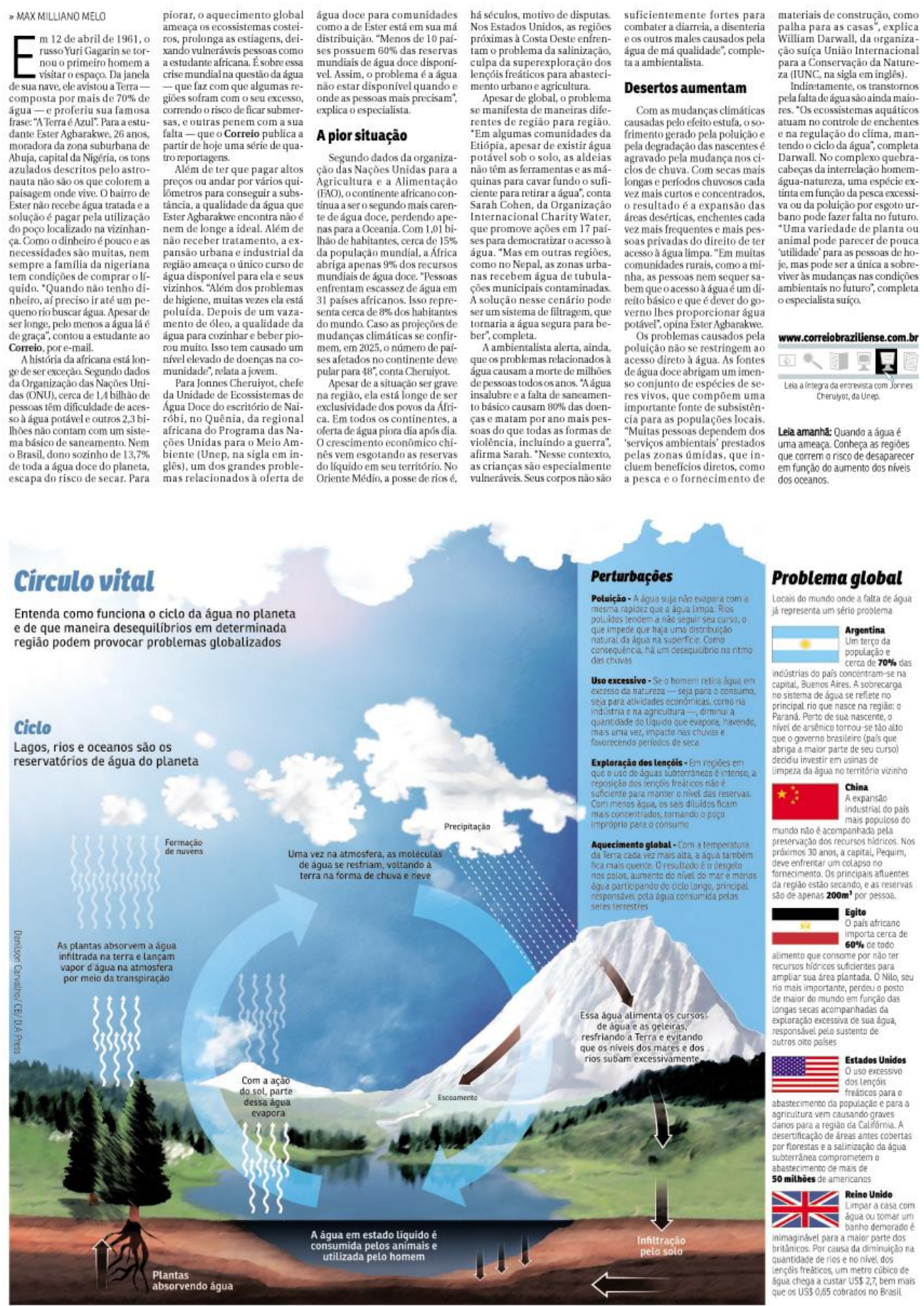
Es. Água em desequilíbrio

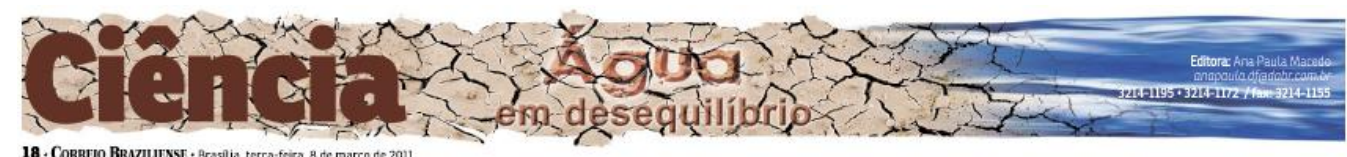

\section{Entre a escassez e 0 excesso}

0 Brasil, dono de $13,7 \%$ de toda a reserva de água doce no planeta, sofre entre estiagens cada vez mais frequentes e intensas e chuvas progressivamente mais destruidoras

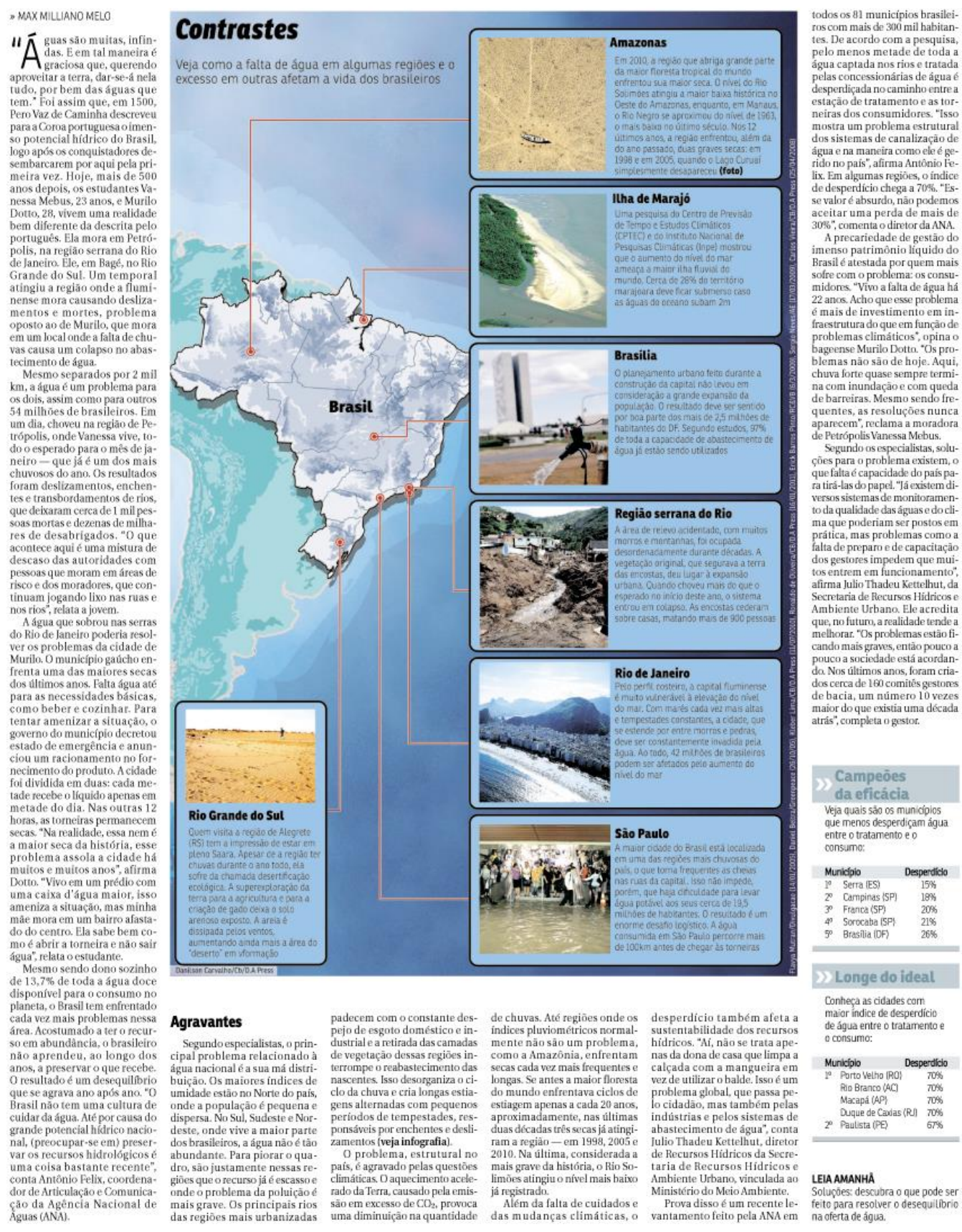




\section{Fórum 3: Debatendo sobre a água}

Prezad@s cursistas,

Vamos apurar nossa visão científica e crítica diante dos fatos e fenômenos que envolvem os recursos naturais do planeta Terra? O tema dessa semana é água. Após a leitura das reportagens desse módulo, "Água: o problema em questão" e "Água em desequilíbrio", vamos refletir acerca das seguintes questões?

1. Como você acredita que o homem tem interferido no ciclo natural da água e sua disponibilização no planeta?

2. Quais medidas podem e devem ser tomadas para minimização do problema em questão a curto prazo?

3. Tomando como base a leitura sugerida de Bacci e Pacatta (2008) "Educação para a água”, elabore um comentário acerca do texto e as discuta com seus colegas, lembrando sempre de escolher uma questão de outro participante para responder e/ou debater.

Bom trabalho a todos! 9

\section{Abordando o tema água no contexto escolar}

Prezad@s participantes,

A referida atividade deverá ser realizada em duplas ou trios e consiste nas seguintes etapas:

A - Faça um balanço do consumo de água em sua região, levando em consideração a quantidade de água que abastece a sua cidade. Liste em uma tabela todos os dados, em seguida com o auxílio de um mapa hídrico do DF ou de sua cidade, localize as principais bacias responsáveis pelo abastecimento populacional.

B - Com base nos seus conhecimentos acadêmicos e na sua experiência profissional, elabore um esquema didático para explicitar o funcionamento do ciclo hidrológico, identificando suas principais etapas e quando possível evidenciando os pontos que mais sofrem alteração pela ação humana. O esquema didático poderá ser realizado em conjunto com o item seguinte, unificando as duas propostas.

C - Como você, professor, abordaria a questão da crise hídrica com seus alunos? Elabore uma sequência didática, com duração de três aulas, enaltecendo os recursos e estratégias didáticas que você empregaria. Não se esqueça de vislumbrar a perspectiva CTS, de modo que a questão ambiental seja colocada em evidência. 


\section{Leituras recomendadas - próxima semana $(07 / 10$ - 15/10)}

ALBAGLI, S. Divulgação científica: Informação científica para a cidadania. Ci. Inf., Brasília, v.25, n. 3, p. 396-404, set./dez. 1996.

MARANDINO, M. Museu e escola: parceiros na educação científica do cidadão. In: CANDAU, Vera Maria (Org.). Reinventar a escola. 3. ed. Petrópolis, RJ: Vozes, p. 189-220, 2000.

SEMANA $4-07 / 10$ a $15 / 10$

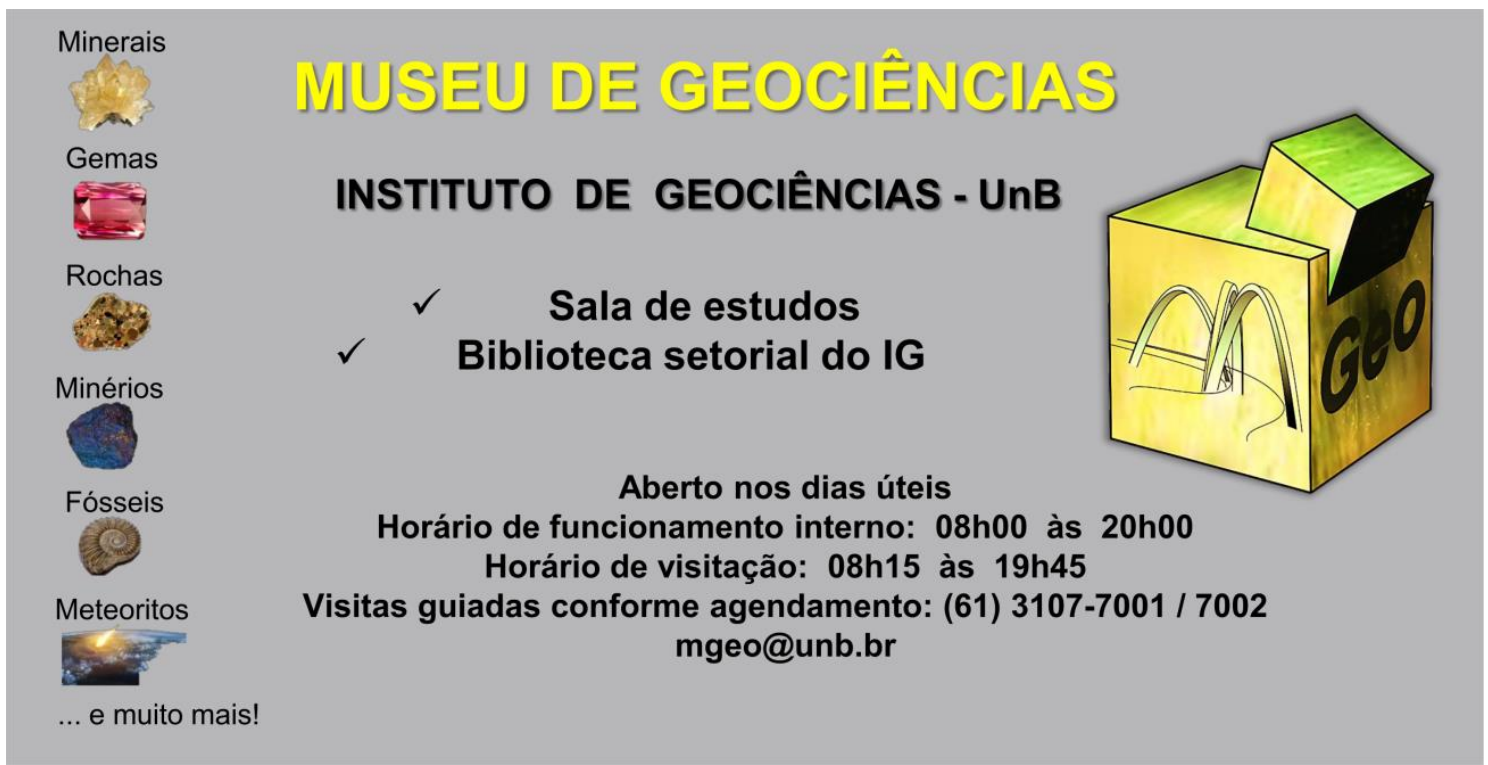

\section{Uma breve história do museu...}

O curso de Geologia da UnB foi criado em 1965, surgindo assim a necessidade de criar uma coleção de amostras para fins didáticos. Dessa forma, o primeiro depósito de amostras foi criado, dedicado à conservação de amostras coletadas em campo por professores e alunos. A partir de 1967, o IG realizou um intercâmbio de amostras com a École des Mines de Paris - França, que resultou nas primeiras coleções sistemáticas para as aulas práticas do curso de geologia. Era em 1971 que, durante um trabalho de campo em Goiás, foi descoberto um meteorito de 279 kg (o meteorito "Sanclerlândia), hoje em exposição no museu. Essa rocha rara e preciosa era o motivo para transformar o depósito em um museu de geociências.

A partir de 2008, o museu vem passando por uma reforma total de seu espaço físico, que atualmente ocupa uma área de cerca de $350 \mathrm{~m}^{2}$. O espaço engloba a biblioteca setorial do IG, uma sala de estudos, e um ambiente de exposições incluindo minerais, gemas, fósseis e rochas. A missão do museu hoje é a 
conservação e ampliação das coleções, e a divulgação das geociências para alunos do IG, interessados da UnB e para a sociedade em geral. A missão é apoiada pela Associação de Amigos do Museu de Geociências.

Fonte: Página do Instituto de Geociências, UnB.

\section{Proposta Didática}

\section{Planejando... 9}

Agora você professor, em individual, duplas ou trios deverá montar um roteiro de visitação, escolha algum espaço de sua região, no nosso caso, do Distrito Federal. Elabore quais atividades serão executadas e quais temas do ensino de Geologia serão explorados, agregando os conhecimentos vistos ao longo do curso. Você terá liberdade para escolher o tema e a possível série/ano que será destinada a atividade proposta. Lembre-se de buscar auxílio na bibliografia, pesquise por autores que possuem pesquisa na área de espaços não formais de ensino e divulgação científica como, por exemplo, Marandino e Albagli.

Bom trabalho!

Samara Anjos

\section{Descrição das Atividades Encontros Presenciais}

\section{Encontro 1 (25/09) - Experimentando: Permeabilidade dos Solos/Erosão e Deslizamentos}

Tema: Solos

\section{Etapa: Separando os materiais}

Para simular a permeabilidade dos solos, iremos utilizar os seguintes materiais: 4 garrafas pets; 4 elásticos; 4 pedaços de tecido $15 \mathrm{~cm} \times 15 \mathrm{~cm}$; 2 L de água; variadas amostras de solo.

Os professores serão divididos em duplas ou trios e cada um simulará a permeabilidade em um tipo de solo específico. 
a. Corte o fundo da garrafa pet, em seguida anexe o pedaço de tecido na boca de cada garrafa;

b. Com o auxílio de um copo de 50 ou $100 \mathrm{ml}$, a água deverá ser aferida, de modoque os valores sejam sempre marcados;

c. Na parte da garrafa que foi cortada (fundo) deverá ser adicionada uma porção do exemplar específico de solo;

d. Condicione a parte de cima da garrafa com a boca para baixo no fundo do copo e adicione uma quantidade fixa de água;

e. Observe o tempo que a água demora para atravessar a coluna do material.

\section{Etapa: Análise dos dados e discussão}

Agora reflita acerca das seguintes questões:

O que aconteceu com o tempo de infiltração da água através das diferentes colunas? Por quê?

Quais efeitos esses diferentes tipos de solo produzem no escoamento e na infiltração da água das chuvas na natureza?

\section{Tema: Erosão e Deslizamentos}

\section{Etapa: Separando os materiais}

Para simular a erosão e deslizamentos dos solos serão utilizados os seguintes materiais: 2 bandejas de plástico $20 \mathrm{~cm}$ x $15 \mathrm{~cm}$; 1 borrifador; 500 $\mathrm{ml}$ de água; solo areno - argiloso. 
a. Monte um sistema simulando uma encosta de um morro com solo arenoargiloso não muito espesso, colocando uma camada de terra compactada em uma bandeja inclinada. Professor: teste antes para ajustar a inclinação da bandeja. Ela deve ter uma inclinação que permita o deslizamento da terra quando molhada, mas não quando a terra está originalmente seca.

b. Em seguida, utilize o borrifador contendo água para simular a ação das chuvas. Borrife por vários minutos e observe o que acontece.

c. Repita o procedimento em outra bandeja utilizando uma camada de terra mais espessa.

\section{Etapa: Análise dos dados e discussão}

Ao simular a ação da chuva, o que aconteceu com a camada de terra nos dois experimentos? Explique.

Quais os principais problemas socioambientais gerados, quando há ocupação de encostas pela população?

Qual a relação do homem estabelecida com o solo?

Quais elementos que estão associados à ocupação indevida potencializam fenômenos como os deslizamentos?

\section{Sugestões de Referências}

PRESS, F, SIEVER R.,GROTZINGER, J. \& JORDAN, T. H., 2006. Para Entender a Terra. Tradução Rualdo Menegat, 4 ed. - Porto Alegre: bookman, 656 p.: il. 


\section{Encontro 2 (09/10) - Modelando o Perfil Tectônico Terrestre Tema: Tectônica de Placas - Relevo}

\section{Etapa: Montagem dos ambientes tectônicos}

a. Inicialmente os professores serão divididos em grupos, cada um receberá um tipo específico de ambiente tectônico para realizar a montagem de um "quebra cabeça tectônico", sendo eles:

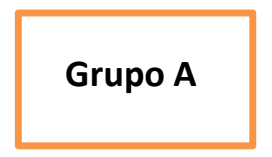

Convergência de placas oceânicas Divergência de placas continentais

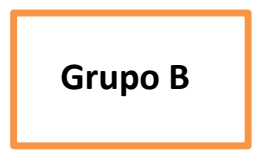

Convergência de placas continentais Divergência de placas oceânicas

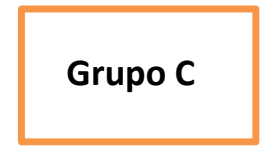

Convergência de placa oceânica continental

Ponto Quente (Hot Spot)

b. Em seguida os grupos receberão "peças" em EVA de cores diversas, estes deverão sobrepor às peças ou pareá-las de modo que possam identificar ao máximo o ambiente tectônico recebido, as peças serão proporcionalmente dimensionadas entre si e preservarão a escala real dos ambientes. Sendo assim, para a montagem correta do perfil cada cor do EVA indica elementos diferentes desse perfil, sendo eles:

AMARELO - Porção inferior da Litosfera (5 peças grandes)

- AZUL - Oceanos ou lagos (3 peças médias)

- LARANJA - Astenosfera (3 peças grandes)

LARANJA (decorado) - Bacias sedimentares e continentais (3 peças médias)

- PRETO (peças maiores) - Crosta Oceânica (5 peças médias)

- PRETO (peças pequenas) - Cinzas e gases vulcânicos (4 peças médias)

- PRETO (peças onduladas pequenas) - Dobramentos (20 peças pequenas)

- ROSA - Crosta continental (3 peças grandes e 1 média)

- VERDE - Setas indicativas do movimento das placas litosféricas (6 peças maiores e 7 peças médias) ou setas indicativas de falhas (6 peças pequenas)

- VERMELHO - Magma (1 peça média e 19 peças pequenas) 


\section{Etapa: Identificação dos Ambientes Tectônicos}

a. Após a montagem dos perfis indicados na etapa anterior, os grupos deverão definir as partes que compõem cada perfil montado, os termos identificados deverão ser escritos à mão, conceituados e organizados sob a forma de uma legenda.

b. Em seguida deverão identificar os tipos de relevo que podem ser formados de acordo com cada ambiente montado.

\section{Sugestões de Referências}

BRYSON, B. Brevíssima história de quase tudo. Companhia das letrinhas. São Paulo. 2010.

CARVALHO, I. C. Educação ambiental e a formação do sujeito ecológico. 2000, p. 91-107.

MURRIE, S.; MURRIE, M. Cada minuto na Terra - coisas que acontecem no planeta a cada 60 segundos. 1 ed. São Paulo. Panda Books. 2009. 


\section{Encontro 3 (15/10) - Visita orientada ao Museu de Geociências da UnB}

\section{Etapa: Organização prévia}

a. Entrar em contato com o monitor do museu a fim de buscar uma parceria para dirigir as atividades durante a visita dos alunos;

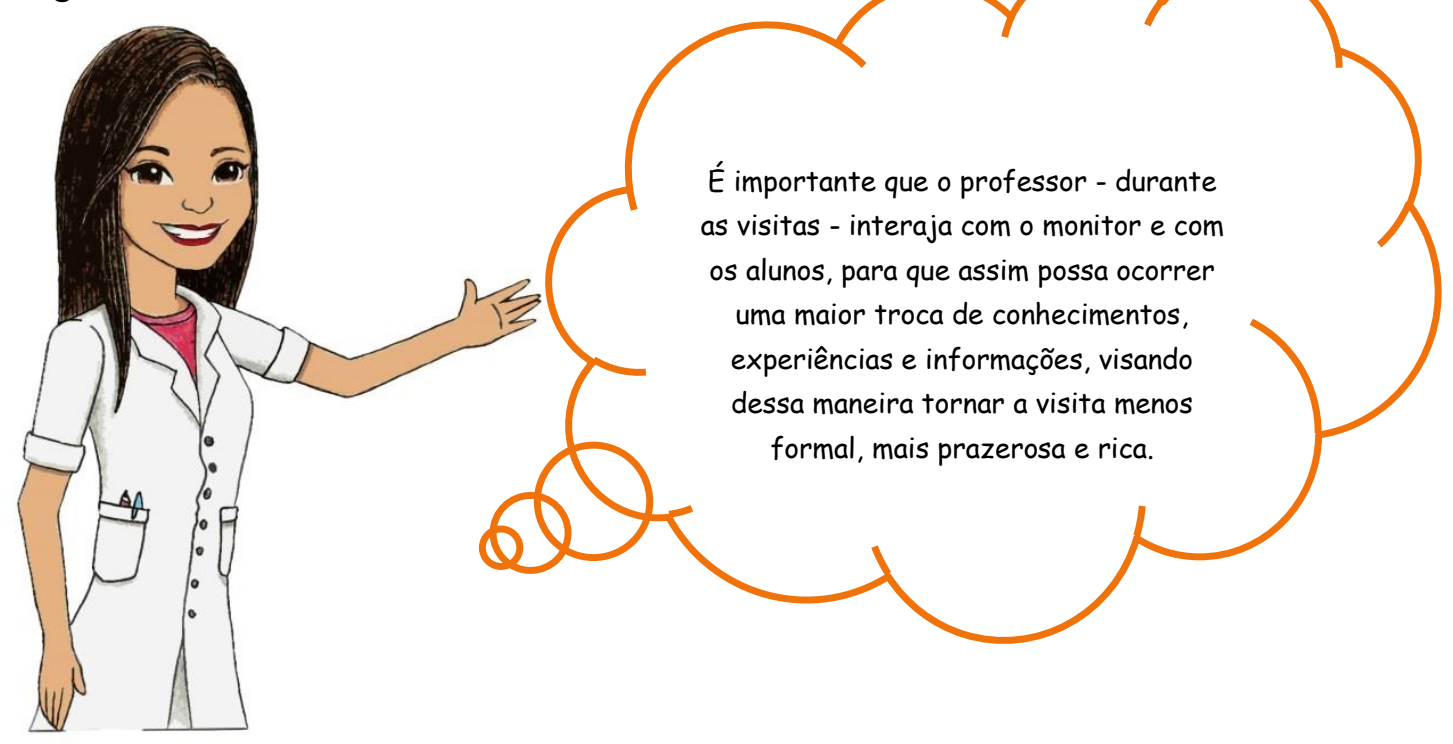

b. O professor deverá conhecer o espaço previamente a fim de explorar todos elementos e vivenciá-los ao máximo, visando a produtividade da visita;

c. Planejar as atividades de acordo com o espaço físico e logística de tempo.

d. Dividir a turma em subgrupos de acordo com as atividades previamente definidas planejadas.
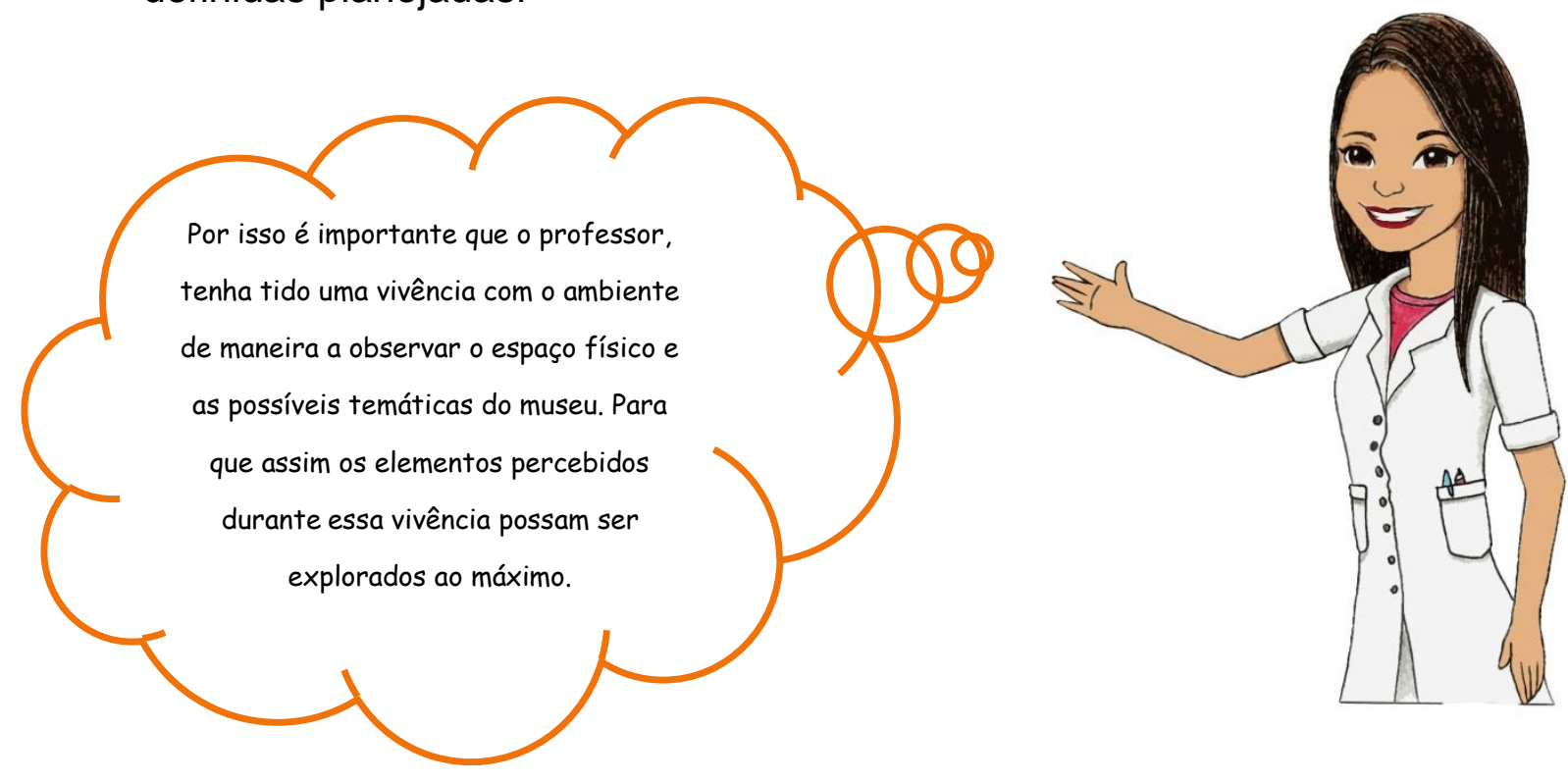


\section{Etapa: Visita ao Museu}

a. O professor deverá dividir a turma em dois grupos ou mais (a quantidade de grupos vai depender do tamanho da turma, do espaço físico e da quantidade de monitores presentes no museu) como, por exemplo, A e B.

b. Sugestões de atividades durante a visita:

Palestra: os alunos poderão conhecer o funcionamento do museu e o que ali está sendo exposto, relembrando o que é, e quais são os tipos de rochas, como ocorre a formação de cada tipo na natureza (ambientes) e conhecer melhor seus constituintes básicos: os minerais. Após essa pequena introdução os alunos poderão aprender a aplicação dos minerais na construção de casas e artefatos utilizados no dia-a-dia, seu uso nos meios de transporte, agricultura e utilização no avanço tecnológico.

Exposição: nessa atividade, os alunos poderão fotografar e desenhar as amostras que ali se encontram expostas. Anotando em uma caderneta o nome de cada mineral e/ou rocha, e algumas de suas características físicas como, por exemplo, cor e tamanho.

Oficina: os alunos serão convidados a construir alguns dos ambientes onde podem ser formadas e encontradas as rochas. Podendo ser eles um vulcão, vale de rifte, bacias de sedimentação, zonas de subducção, encontro de placas, formação de relevos, entre os ' $n$ ' números ambientes formadores de rochas que podemos ter no planeta Terra.

Simulação: por meio de uma simulação visual ou de software os alunos poderão conhecer como ocorre à dinâmica do ciclo das rochas no planeta Terra. Compreendendo que o processo nunca tem fim, ocorre em todas as partes do mundo, formando e erodindo montanhas em um local, depositando e soterrando sedimentos em outros. Os alunos poderão ter a possibilidade de ver toda a dinâmica, compreendendo que as rochas são recicladas continuamente.

c. Cada uma das quatro atividades expostas anteriormente poderá ter uma duração de no máximo 60 minutos cada, não importando a ordem de execução das mesmas, pois cada atividade pode ser trabalhada de forma 
independente. Isso porque enquanto um grupo de alunos realiza uma oficina ou conhece a exposição, outro grupo poderá estar assistindo a uma palestra ou participando de uma atividade de simulação, de forma que todos os grupos possam participar de todas as atividades ali propostas.

\section{Etapa: Avaliação}

a. Após uma gama de atividades ocorridas dentro do museu, os alunos serão chamados a depositar todos os conhecimentos ali adquiridos, uma das sugestões é redigir um relatório.

b. Cada aluno escolherá um tipo de rocha e um mineral encontrado nessa rocha para descrever.

c. Deverá constar no relatório o ambiente de formação dessa rocha, onde são encontradas, suas principais características, e discorrer sobre um dos minerais mais comuns encontrados nessa rocha, suas características físicas, importância econômica e seu emprego na confecção de materiais ou objetos utilizados em nosso cotidiano.

d. Os alunos deverão usar as informações adquiridas durante a sua visita ao museu, poderão anexar as fotos ou desenhos que foram feitos na atividade de exposição. Será atribuída uma pontuação ao relatório dos alunos.

\section{Sugestões de Referências}

ALBAGLI, S. Divulgação científica: Informação científica para a cidadania. Ci. Inf., Brasília, v.25, n. 3, p. 396-404, set./dez. 1996.

MARANDINO, M. Museu e Escola: parceiros na educação científica do cidadão. In CANDAU, V. M. F.(org) Reinventar a Escola. Editora Vozes, Petrópolis, 2000.

PRESS, F, SIEVER R.,GROTZINGER, J. \& JORDAN, T. H., 2006. Para Entender a Terra. Tradução Rualdo Menegat, 4 ed. - Porto Alegre: bookman, 656 p.: il.

VAINE, G. E. M. E. A sua Casa vem da Mineração. Os Minerais e Você. Série Geologia na Escola. Caderno 3. 


\section{Ambiente Virtual do Curso: \\ "Educação em Geologia"}

Eurso: Educação em Geolc $x$

$\leftarrow \rightarrow$ C กี่ $\square$ aprender.ead.unb.br/course/view.php?id $=3086$

UnB APRENDER

Página inicial / Meus cursos / Campus Darcy Ribeiro / Decanato de Extensão / Educação em Geologia

Apresentação - Ambientação na Plataforma

Formação Continuada de Professores: "Educação em Geologia"

Professora/ministrante: Samara Anjos

Coordenadoras: Prof.a Alice Melo Ribeiro e Prof.a Anete Maria de Oliveira

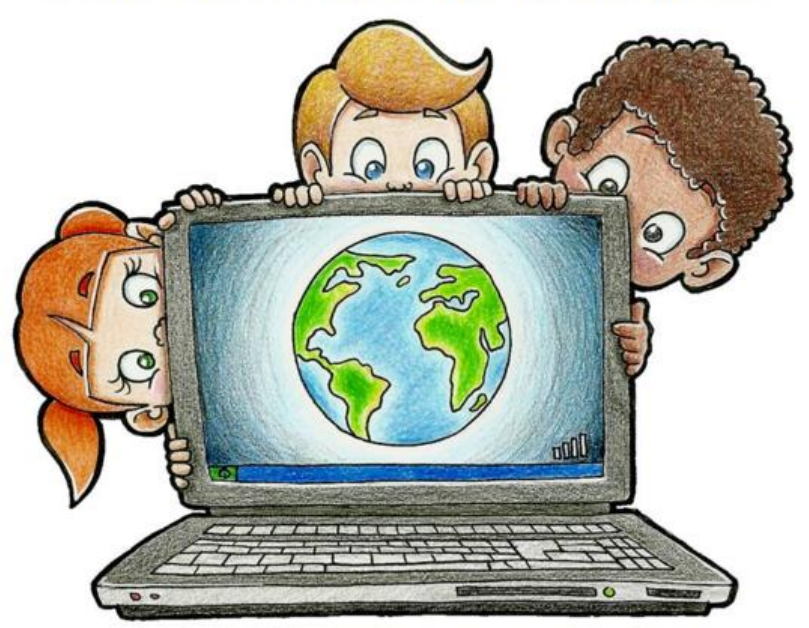

Ilustrações: Stefanne Souza Laia

Guia do curso Educação em Geologia

Sala do cafezinho

Fórum de noticias

Fórum de dúvidas

Terminologias Geocientíficas (Glossário) 
Curso: Educação em Geolc $x$

$\leftarrow \rightarrow$ C ก̂ $\square$ aprender.ead.unb.br/course/view.php?id=3086

Semana I - 15/09 a 22/09

Debatendo sobre a formação do Planeta Terra e o Sistema Solar/Tempo Geológico

"Dust in the wind, all we are is dust in the wind."

"Poeira no vento, tudo o que somos é poeira no vento."

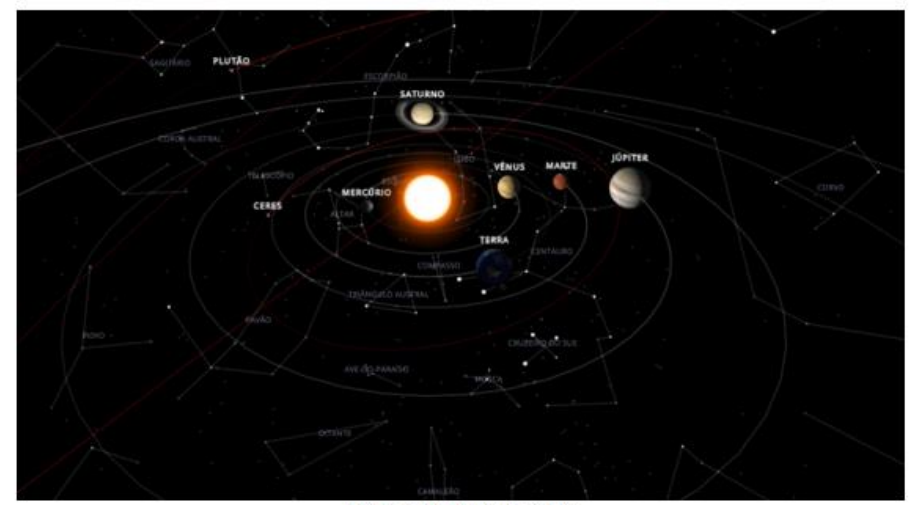

Fonte: Solar System Scope

C. Tome nota Professor. Software Solar System Scope

(8) Você, o planeta Terra e o Sistema Solar - Ponto de vista químico

Fórum 1: Debate Científico

Explanando minha teoria científica

A A idade da Terra

Leituras recomendadas - próxima semana (23/09 - 28/09)

Wurso: Educação em Geolc $x$

$\leftarrow \rightarrow$ C ก D aprender.ead.unb.br/course/view.php?id=3086

Semana II - 23/09 a 28/09

Minerais e Rochas/Solos

"Aorendi o segredo da vida, vendo as pedras que sonham sozinhas no mesmo lugar:"

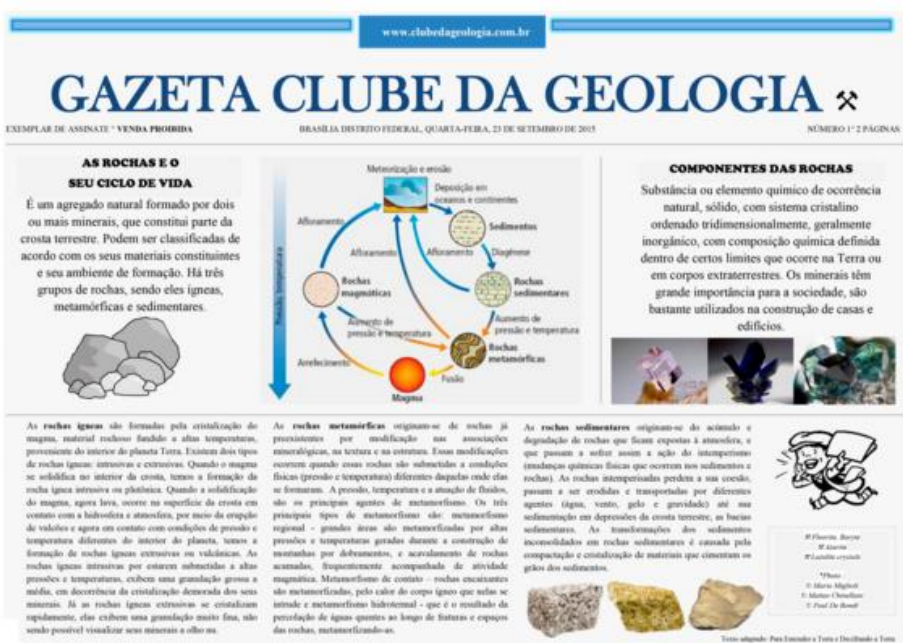

'(2) Animação - "Minha nada mole vida"

Fïrum 2: Saber Cientifico $x$ Saber Comum

Dexplanando os Minerais e Rochas

(2) Intemperismo e Solos

Elaborando textos com enfoque CTS

Leituras recomendadas - próxima semana (29/09 a 06/10) 
Eurso: Educação em Geok $x$

$\leftarrow \rightarrow$ C กี $\square$ aprender.ead.unb.br/course/view.php?id=3086

Semana III - 29/09 a 06/10

\author{
Ciclo Hidrológico
}

"Ô chuva vem me dizer, se posso ir lá em cima pra derramar você."

Marisa Monte

Ponto de partida

Os fenômenos dos quais a água participa, como intemperismo, erosão, assoreamento, circulação do ar, clima, dissolução de substâncias, são fundamentais para a organizaçäo da superficie terrestre em todas as suas esferas, sendo elas a litosfera, biosfera, hidrosfera e atmosfera. A compreensão desses dominios, bem como as inter-relaçôes entre eles, ajuda a construir a ideia da dinâmica da Terra.

Recurso natural indispensável para a manutenção da vida, a água tornou-se a preocupação iminente das últimas décadas, São Paulo, estado localizado na região sudeste do país, tem vivenciado atualmente umas das priores crises com a falta de água.

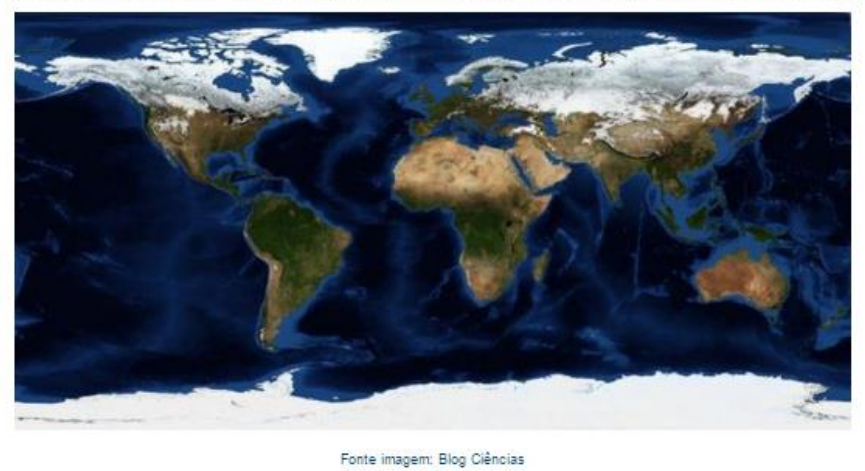

Neste contexto a interação entre ciência, tecnologia e sociedade propiciará o desenvolvimento de valores e ideias por meio de estudos de temas locais, políticas públicas e temas globais, atentando os educandos quantos às problemáticas que emergem cotidianamente em nossa sociedade.

A utilização de atividades com ênfase em CTS (Ciência-Tecnologia-Sociedade) no contexto da educação brasileira visa beneficiar o ensino e aprendizagem do educando, uma vez que se busca preparar o aluno para o exercício da cidadania consciente, com foco para reflexões, capacitando-os a analisar problemáticas ambientais indo ao encontro de possiveis soluções (SANTOS e MORTIMER, 2002).

W Curso: Educação em Geolc $\times$

Leia atentamente o seguinte noticiário

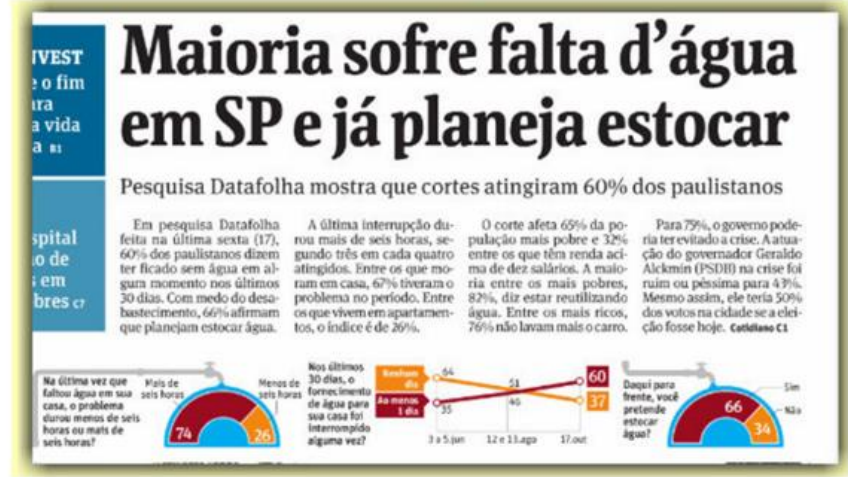

Agora é hora de propor!

\footnotetext{
๔. Água: o problema em questão

'ธ Água em desequilíbrio

를 Fórum 3: Debatendo sobre a água

4. Abordando o tema água no contexto escolar
}

Leituras recomendadas - Próxima semana (07/10 a $15 / 10$ 


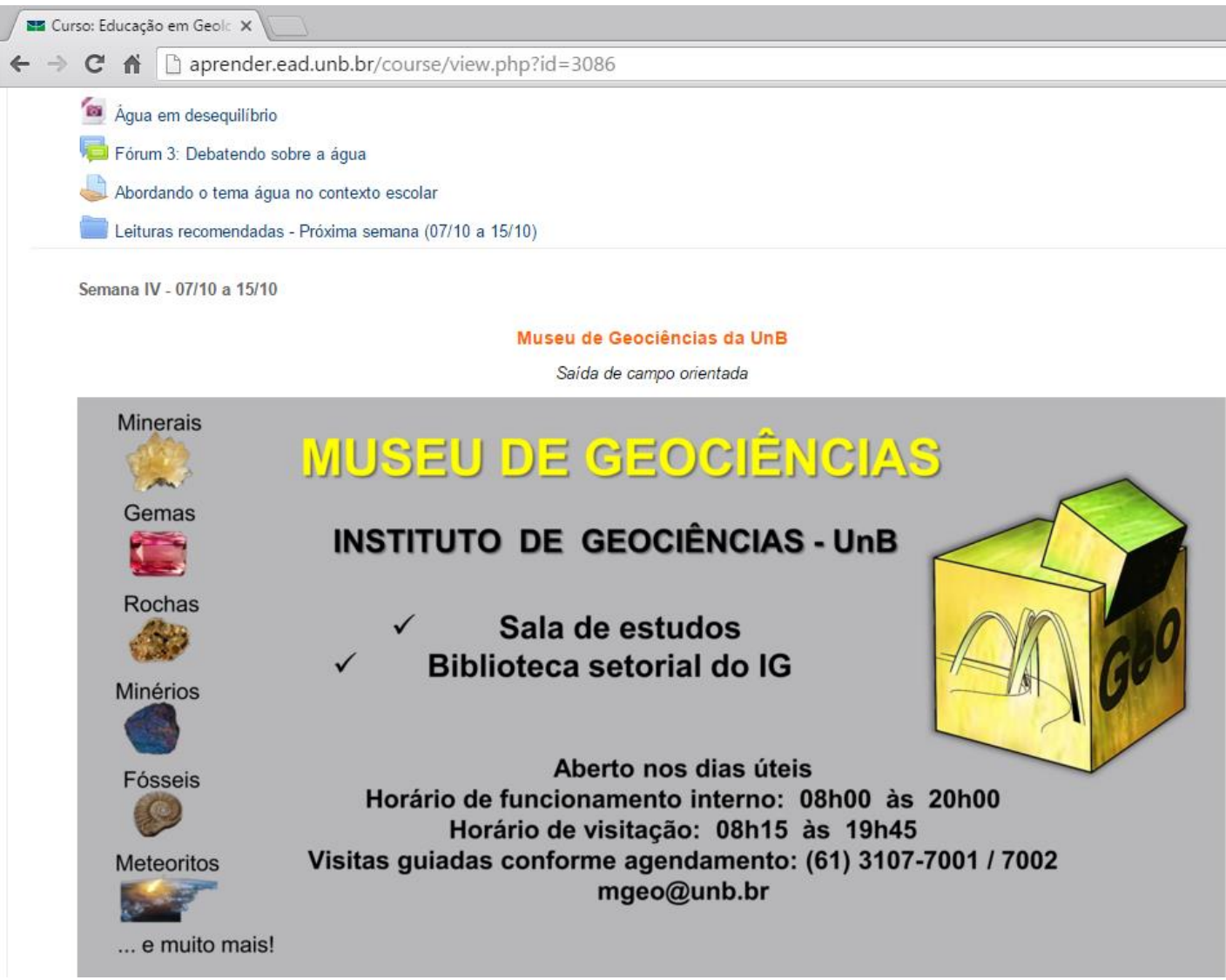

Uma breve história do museu

O curso de Geologia da UnB foi criado em 1965, surgindo assim a necessidade de criar uma coleção de amostras para fins didáticos. Dessa forma, o primeiro depósito de amostras foi criado, dedicado à conservação de amostras coletadas em campo por professores e alunos. A partir de 1967, o IG realizou um intercâmbio de amostras com a École des Mines de Paris - França, que resultou nas primeiras coleções sistemáticas para as aulas práticas do curso de geologia. Era em 1971 que, durante um trabalho de campo em Goiás, foi descoberto um meteorito de 279 kg (o meteorito "Sanclerlândia), hoje em exposição no museu. Essa rocha rara e preciosa era o motivo para transformar o depósito em um museu de geociências.

A partir de 2008, o museu vem passando por uma reforma total de seu espaço físico, que atualmente ocupa uma área de cerca de $350 \mathrm{~m}^{2}$. $\mathrm{O}$ espaço engloba a biblioteca setorial do IG, uma sala de estudos, e um ambiente de exposições incluindo minerais, gemas, fósseis e rochas. A missão do museu hoje é a conservação e ampliação das coleções, e a divulgação das geociências para alunos do IG, interessados da UnB e para a sociedade em geral. A missão é apoiada pela Associação de Amigos do Museu de Geociências. 


\section{REFERÊNCIAS BIBLIOGRÁFICAS}

ALBAGLI, S. Divulgação científica: Informação científica para a cidadania. Ci. Inf., Brasília, v.25, n. 3, p. 396-404, set./dez. 1996.

BACCI. D, de La C.; PATACA. E, M. Educação para a água. São Paulo, v. 22, n. 63, 2008.

CARNEIRO, M. H.; GASTAL, M. L. História e Filosofia das Ciências no Ensino de Biologia, in Ciência \& Educação, v. 11, n. 1, p. 33-39, 2005.

LAVILLE, C.; DIONNE,J. A construção do saber: manual de metodologia da pesquisa em ciências humanas. Porto Alegre: Editora Artes Médicas Sul Ltda; Belo Horizonte: Editora UFMG, 1999.

MARANDINO, M. Museu e Escola: parceiros na educação científica do cidadão. In CANDAU, V. M. F.(org). Reinventar a Escola. Editora Vozes, Petrópolis, 2000.

NÓVOA, A. Imagens do futuro presente. Lisboa, Portugal: EDUCA, 2009.

PIMENTA, S. G. Pesquisa-ação crítico-colaborativa: construindo seu significado a partir de experiências com a formação docente. Educação e Pesquisa. São Paulo, n. 3, v. 31, p. 521539, set./dez. 2005.

PRESS, F.; SIEVER R..; GROTZINGER, J.; JORDAN, T. H. Para Entender a Terra. Tradução Rualdo Menegat, 4 ed. - Porto Alegre: bookman, 656 p. 2006.

SANMARTÍ, N. Enseñar a elaborar textos científicos en las clases de ciencias. In: Alambique - Didática de las Ciencias Experimentales - linguagem e comunicacion, $\mathrm{n}^{\circ}$ 12, abril, Edições GRAÓ, p. 51-61, 1997.

SANTOS. W. L. P.; MORTIMER. E. F. Uma análise dos pressupostos teóricos da abordagem C-T-S (Ciência - Tecnologia - Sociedade) no contexto da educação brasileira. Ensaio, Pesquisa em Educação, n. 2, v. 2, p. 1-23, 2002.

SIMÕES, M. G.; RODRIGUES, S. C. Livro Digital de Paleontologia: a paleontologia na sala de aula. 2009. Disponível em: http://www.paleontologianasaladeaula.com/. Acesso em: 14 de jun. 2015. 
TOLEDO, M. C. M. Geociências no Ensino Médio Brasileiro - Análise dos Parâmetros Curriculares Nacionais. Revista do Instituto de Geociências - USP, Publ. Espec. v. 3, p. 31 44, set, 2005.

TEIXEIRA, W.; TOLEDO, M. C. M.; FAIRCHILD, T. R.; TAIOLI, F. Decifrando a terra. São Paulo: Oficina de textos, 2003. 558p. 